Did the Bologna Process Challenge the German Apprenticeship System? Evidence from a Natural Experiment

Stephan L. Thomsen Johannes Trunzer 


\title{
Did the Bologna Process Challenge the German Apprenticeship System? Evidence from a Natural Experiment*
}

\author{
Stephan L. Thomsen ${ }^{\dagger} \quad$ Johannes Trunzer ${ }^{\ddagger}$
}

October 2020

\begin{abstract}
Starting in 1999, the Bologna Process reformed the German five-year study system for a first degree into the three-year bachelor's (BA) system to harmonize study lengths in Europe and improve competitiveness. This reform unintentionally challenged the German apprenticeship system that offers three-year professional training for the majority of school leavers. Approximately 29\% of new apprentices are university-eligible graduates from academic-track schools. We evaluate the effects of the Bologna reform on new highly educated apprentices using a generalized difference-in-differences design based on detailed administrative student and labor market data. Our estimates show that the average regional expansion in first-year BA students decreased the number of new highly educated apprentices by $3 \%-5 \%$; average treatment effects on those indecisive at school graduation range between $-18 \%$ and $-29 \%$. We reveal substantial gender and occupational heterogeneity: males in STEM apprenticeships experienced the strongest negative effects. The reform aggravated the skills shortage in the economy.
\end{abstract}

JEL Codes: I23, I28, J24

Keywords: Bologna Process, post-secondary education decisions, apprenticeships, higher education

${ }^{*}$ We are grateful to Jens Ruhose, Guido Schwerdt, Stefan Bauernschuster, Gregor Pfeifer, Marc Piopiunik, Uschi Backes-Gellner, and seminar and conference participants at the annual meeting of the Verein für Socialpolitik (Leipzig), the conference of the Centre for Vocational Education Research (London), and the Core Course "Econometric Methods in Economics of Education" of the 6th Course Programme for Doctoral Students in Economics of Education (Zurich) for their most helpful comments and discussions. Financial support by the Leibniz Center for Science and Society (LCSS) at the Leibniz University Hannover through the project "Evaluation der Folgen von Studienstrukturreform und Hochschulexpansion für die Arbeitsmarkterträge von Hochschulabsolventinnen und -absolventen" is gratefully acknowledged. The data basis of this paper is the weakly anonymous Sample of Integrated Labor Market Biographies (SIAB) 1975 - 2014. The data were accessed on-site at the Research Data Centre (FDZ) of the Federal Employment Agency (BA) at the Institute for Employment Research (IAB) and/or via remote data access at the FDZ.

${ }^{\dagger}$ Leibniz University Hannover, Institute of Economic Policy, Königsworther Platz 1, 30167 Hannover, ZEW Mannheim, and IZA Bonn; E-mail: thomsen@wipol.uni-hannover.de

${ }^{\ddagger}$ Leibniz University Hannover, Leibniz Center for Science and Society (LCSS) and Institute of Economic Policy, Lange Laube 32, 30159 Hannover; E-mail: trunzer@wipol.uni-hannover.de 


\section{Introduction}

In recent decades, many countries have expanded university education to foster technological progress and economic growth. In addition to university education as a primary source of qualified labor, some countries, such as Germany - or, less recognized, Switzerland, Austria and Denmark - have a so-called dual apprenticeship system. It provides professional training for a large part of the population 11 This system is believed to create economic benefits through two main channels: (1) occupation-specific skill formation in combination with close links between trainees and employers can facilitate the labor market entry of youth (see, e.g., Ryan, 2001; Zimmermann et al., 2013), and (2) firms' views of apprenticeships can be both production-oriented, as a source of cheap labor, and investment-oriented, as a way to secure their future supply of skilled workers (Mohrenweiser and Backes-Gellner, 2010; Wolter and Ryan, 2011). Originally, the dual apprenticeship system in Germany targeted school leavers from the non-academic track. However, since there is no restriction on who may participate, many high school graduates from the academic track have also been trained.2 This group has become increasingly important due to the size of its supply over recent years. In 2017, $29 \%$ of new apprentices were qualified for university - compared to $16 \%$ in 2000 (BIBB, 2009, 2019).

Against this backdrop, we investigate the question of whether the introduction of bachelor's (BA) degrees due to the Bologna Process initiated in 1999 has challenged the dual apprenticeship system. In Germany, the former single-cycle degree system - awarding, e.g., the so-called Diplom degree - was replaced by a new two-cycle system of consecutive BA and master's (MA) degrees. ${ }^{3}$ As a result, the hurdles to obtaining a first university degree were lowered (reductions in study length and effective costs), which arguably increased the attractiveness of a university education compared to apprenticeship training. In addition, employability - the former unique selling point of apprenticeships - was introduced as a key feature of academia. Therefore, high school graduates from the academic track, i.e., those who are eligible for both a university education and an apprenticeship, may increasingly opt for a university education rather than apprenticeship training. We present evidence on this hypothesis and estimate the effect of the introduction of BA degrees on the regional supply of highly educated apprentices. In doing so, we reveal trade-offs within the post-secondary education system that could limit the potential benefits of university education expansion policies.

\footnotetext{
${ }^{1}$ In Germany, vocational education and training (VET) represents the most common qualification level of the population aged 15 years or older (48\% in 2017 (Destatis, 2018a)), and it is the largest sector of postsecondary education (BIBB, 2019, see also Figure A-1 in the appendix). The definition of VET includes both dual apprenticeship training and full-time vocational schools, with the former accounting for the significantly larger share.

${ }^{2}$ The academic track in German high schools provides the prerequisites for going to university.

${ }^{3}$ There are still very few exceptions: Courses leading to the regulated professions in law and medicine still award the so-called state certificate (Staatsexamen). The same holds for teaching courses in some German federal states, such as Bavaria. Later, at the Ministerial Conference Berlin 2003, the doctoral level was included as a third cycle of the new degree system.
} 
For the empirical analysis, we make use of a combined panel data set on the level of 141 German regional labor markets delineated by commuter links for the observation period 1997 to 2011. Hence, we cover the whole implementation process from 1999 to 2010 plus two additional pre-treatment years and one year afterwards. Our data set contains detailed administrative data from the Federal Statistical Office (Destatis) on first-year students, which allows us to exploit regional, temporal and area-of-study variation in the demand for BA courses. These data are matched with information on new apprentices per region, occupational area and year from the Sample of Integrated Labor Market Biographies (SIAB) provided by the Institute for Employment Research (IAB). Using information on the type of school qualification, we can identify the number of new highly educated apprentices, i.e., those who come from the academic school track and are eligible for both a university education and an apprenticeship.

Our identification strategy uses a generalized difference-in-differences (DiD) approach 4 Due to the specific institutional context of the Bologna Process in Germany, the expansion of first-year BA students in Germany exhibits high spatial and temporal variation. First, federal states set the legal framework on the extent to which the reform had to be implemented. Second, universities could freely decide on the timing of the implementation of the new program structure, as long as it was completed by 2010 . This led to large differences in reform adoption between universities, between departments within universities, and, hence, between regions and areas of study over time. Since there is little evidence of anticipation effects, we can exploit the expansion of BA degrees as a natural experiment that is arguably exogenous to the post-secondary education decisions of school leavers from the academic track. This setup enables us to estimate the causal effect of the expansion of first-year BA students on the supply of new highly educated apprentices on the level of regional labor markets. We conduct an event study that allows us to show that regions with different adoption paths for BA programs had parallel trends in new highly educated apprentices before the policy change.

Our empirical estimates show that the regional expansion of first-year BA students across the whole observation period on average leads to a decrease in the number of new highly educated apprentices by 3\%-5\%. This effect is robust to a large set of different specifications (including region-specific linear time trends) and is supported by falsification tests on less-educated apprentices. This suggests that the introduction of the BA degree system due to the Bologna Process challenged the dual apprenticeship system, as more high school graduates from the academic track have decided against apprenticeships.

Our results further reveal important gender and occupational heterogeneity. The negative effects seem to be driven in particular by males $(-5 \%)$, whereas there is little

${ }^{4}$ Similar approaches can be found in, e.g., Berlinski et al. (2009), Havnes and Mogstad (2011), Bauernschuster et al. (2016), and Sandner and Thomsen (2020) in the context of child care reforms, Ruhose et al. (2020) in the context of a partial retirement reform and elderly learning and Cantoni et al. (2017) in the context of evaluating the effects of a school curricula reform on students' political attitudes in China. 
evidence for overall effects for females. Looking at different occupational areas, the largest negative effects are found for "science, technology, engineering, and mathematics (STEM)" occupations, which are entirely attributable to changes in decisions by men $(-7 \%$ to $-11 \%)$. Smaller negative effects $(-3 \%$ to $-4 \%)$ are estimated for the biggest occupational area, "business"- but only for women. Scaling the intention-to-treat effects (ITT) with the share of school leavers who are indecisive half a year before graduation, we obtain even larger average treatment effects on the treated (ATT) for the full sample of between $-18 \%$ and $-29 \%$, and for males of $-29 \%$. Moreover, differentiating the number of first-year BA students by areas of study reveals not only an increase in educational attainment (upgrading) but also some adjustments in major choice. For instance, the decrease in new highly educated male apprentices in STEM occupations is caused by an increase in first-year BA students in STEM, economics and "health, social work, education" majors. These switches in occupational pathways to different, albeit mostly related, fields could have consequences for future returns to university education, as different fields of study offer different payoffs (Altonji et al., 2012, Kirkeboen et al., 2016).

These findings may have important consequences for economic, individual and fiscal returns to education. First, a lower supply of highly educated apprentices aggravates the skills shortage in Germany, as apprenticeship training helps to reduce the number of unfilled qualified jobs (Bellmann and Hübler, 2014). The skills shortage exists in particular in those professions (STEM) where we find the strongest negative effects (Seyda and Bußmann, 2014). Second, with respect to expected individual returns to education, there may be adverse impacts at different stages of one's career. Since vocational education and training (VET) graduates generally have higher employment probabilities in the early stages of their career than university graduates (Brunello and Rocco, 2017; Golsteyn and Stenberg, 2017; Hanushek et al., 2017), young labor market entrants may encounter greater difficulties in finding adequate jobs initially. Over the life cycle, however, university graduates in Germany typically recoup their relative losses and earn on average 420,000 euros more than VET graduates (Pfeiffer and Stichnoth, 2015). Third, the net average fiscal return to a university graduate (5 years) compared to a VET graduate (4 years) is estimated at between 100,000 euros (Pfeiffer and Stichnoth, 2015) and 130,000 euros (OECD, 2014). Thus, a reduced supply of highly educated apprentices implies a net fiscal gain for government budgets. Conducting a simple back-of-the-envelope calculation based on these numbers, our estimate of 16,600 to 27,600 fewer new highly educated apprentices over the whole observation period could result in a net fiscal gain of approximately 1.66 to 3.59 billion euros in total - assuming a one-to-one replacement of VET with university graduates. Since fiscal returns for highly educated apprentices are probably larger than the average return, our back-of-the-envelope calculation can be considered an upper bound estimate of the overall effect and should be interpreted with care. For instance, the different returns to education further depend very much on wage adjustments due to a 
higher supply of university educated workers, shifts in the skill distribution of graduates with new and former degrees, as well as the quality of their job matching.

This paper contributes to at least three strands of related literature. First, we add evidence on the evaluation of the Bologna Process with respect to post-secondary education decisions. To date, existing research has provided mixed results. Some studies find positive effects on university enrollment for Italy Cappellari and Lucifora, 2009, Di Pietro, 2012, Bondonio and Berton, 2018) as well as for Portugal (Cardoso et al., 2008). For Germany, in contrast, no effects on total enrollment (Horstschräer and Sprietsma, 2015) or on the participation of students from low socio-economic backgrounds (Neugebauer, 2015) have been reported. Compositional changes in post-secondary education entrants, however, have not been considered in that literature. Indeed, our results suggest that the reform affected very specific groups of school leavers: in particular, men who are likely to take technical apprenticeships seem to evaluate their probability of success at university higher than they did before. By focusing on the dual system, we thus reveal unintended side effects that need to be considered to fully evaluate the reform. Second, we contribute to the literature on post-secondary education choices by providing evidence on how changes in incentive structures affect choices between different educational pathways on an aggregate level. In particular, we tie in with the rational action theory literature, conceptualized by Breen and Goldthorpe (1997) and empirically tested, for instance, by Becker and Hecken (2009). Our results support the effectiveness of the "perceived probability of success" channel (see above), as well as the "reduction in study costs" channel, as school leavers seem to have switched to BA courses, especially in those regions and years with tuition fees in effect. Third, we add evidence on the responsiveness of the dual apprenticeship system to shifts in supply or demand. Available studies for Germany have looked at exogenous supply shocks due to an expansion of high school graduate cohorts and report an increase in the number of training contracts, indicating elastic apprentice demand of firms and no crowding-out of less-educated persons (Price et al., 2017; Muehlemann et al., 2018). Another set of studies focuses on the reaction of the apprenticeship system to economic crises (see, e.g., Brunello, 2009, Bellmann et al., 2014; Lüthi and Wolter, 2020). Adding to this literature, our results point towards a limited substitutability (if any) between apprentices of different qualifications, as less-educated apprentices benefit only marginally from less competition with highly educated apprentices.

The remainder of this paper is structured as follows: First, we outline the institutional framework and give an overview of the literature to date (Section 2). After a short description of our data (Section 3), we discuss the empirical strategy and its underlying identification assumptions (Section 4). Section 5 presents the empirical results including heterogeneity analyses and robustness checks. Section 6 discusses magnitudes and conducts a cost-benefit analysis. Section 7 concludes. 


\section{Institutional Background}

\subsection{The German Education System}

After four years of elementary school, German pupils aged approximately ten years old are divided into three different tracks that have traditionally implied very distinct career pathways (see Figure 1): the academic track in high schools provides the prerequisites for going to a university or university of applied sciences (Abitur).5 Approximately threequarters of these graduates actually make use of their university entrance qualifications, while a bit less than the remaining quarter enters the VET system (Schneider et al. 2017). These ratios have remained fairly stable since the early 2000s. However, since the share of high school graduates from the academic track has risen, they have become increasingly important for the apprenticeship market. While in 2000, only $16 \%$ of all new apprentices had a university entrance qualification, by 2017, their share had almost doubled to $29 \%$ (BIBB, 2009, 2019).

\section{$<$ Insert Figure 1 here $>$}

In contrast, school leavers that do not achieve the highest formal school certificate can either enter the labor market directly or enter the VET system, which allows them to achieve at least a medium-skill level. Traditionally, high school graduates with a secondary general school certificate (Hauptschulabschluss) have headed mostly towards blue-collar occupations or handicrafts, while high school graduates with an intermediate school certificate (Mittlerer Schulabschluss) have aimed more for white-collar professions. Due to the educational expansion over the last decades, the separation of these different career pathways has eroded, but it still holds to some extent.

Inside the VET system, three different tracks can be chosen. The most common (49\% in 2017 (AGER, 2018) ) is the dual apprenticeship system, where on-the-job training is combined with formal education in vocational schools. Alternatively, school leavers can opt for vocational education that consists solely of full-time schooling ( $22 \%$ in 2017 (AGER, 2018) ) or they can be placed in the so-called transition system (29\% in 2017 (AGER, 2018), which is designed to absorb excess supply and prepare school leavers for a subsequent apprenticeship (Riphahn and Zibrowius, 2016), but has recently lost much of its importance (see Figure A-1 in the appendix).

The German dual apprenticeship system (first track) can be characterized as highly regulated, institutionalized and competitive. Currently, there are 325 officially recognized training occupations (BIBB, 2019). Training in each of those professions is undertaken in accordance with the respective nation-wide training regulations, where length, professional skills subject to the vocational training, curricula and examination requirements are

\footnotetext{
${ }^{5}$ At German universities, there are basically no admissions tests. Instead, the selection of students is ensured by graduation from an academic-track high school.
} 
specified (Vocational Training Act $(\mathrm{BBiG}) \S 4,2$ and $\S 5,1$ ). The length of an apprenticeship should be in general no longer than three and not less than two years, although there are (very few) exceptions. The vast majority, however, lasts three years (76\% of all recognized occupations in 2018 (BIBB, 2019) ).

During that time, apprentices spend one or two days per week in vocational schools, and the rest in on-the-job training. Hence, the dual system combines general skill formation, such as basics in mathematics and science or language skills, with occupation-specific knowledge. Nevertheless, training is considered to be general in nature, as standardized curricula restrict firms' ability to provide firm-specific skills (Mohrenweiser et al., 2019).

Firms usually have to bear net costs per apprentice and year of approximately 5,400 euros on average, according to the latest survey of the Federal Institute for Vocational Education and Training (BIBB) from 2012/13 (Wenzelmann et al., 2015).6 These net costs are derived from returns of approximately 12,500 euros from productive work and gross costs of approximately 17,900 euros consisting of expenses for trainers and training infrastructure as well as the apprentice's wage, which is usually bargained for between the social partners (employers and unions) for a specific industry and in a specific region. In 2017, monthly apprentice wages were 876 euros on average. Regions in East Germany and the crafts sector had substantially lower wages, while regions in West Germany and the "Industry and Commerce" sector pay above-average wages. For instance, the highest wages are paid for bricklayers (1,159 euros) and mechatronics engineers (1,088 euros), whereas the lowest are paid for hair stylists (584 euros) and chimney sweepers (518 euros) (BIBB, 2019).7

Despite these average net costs, firms are willing to train. Since retention rates are high (68\% in 2016 (AGER, 2018)), they can save on hiring costs later on (Mohrenweiser and Zwick, 2009, Blatter et al., 2016) and use training as a screening device to find the most able and best-matched employees by exploiting information asymmetries Acemoglu and Pischke, 1998, 1999). Firms that follow investment-oriented strategies therefore show a highly selective hiring practice and are not willing to train those with an educational level below a certain threshold (Muehlemann et al., 2018). Indeed, Price et al. (2017) and Muehlemann et al. (2018) find that exogenous supply shocks to high-quality applicants are accompanied by a right-ward shift in firms' apprentice demand. This holds in particular for medium- and large-sized firms from the "Industry and Commerce" sector, which tend to have large internal markets and can attract the most qualified school leavers (Mohrenweiser and Backes-Gellner, 2010). As a result, high school graduates from the academic track tend to opt for very specific, mostly clerical jobs. For instance,

\footnotetext{
${ }^{6}$ However, motivations can be heterogeneous, as some firms are able to recoup training costs and pursue substitution-oriented strategies (Mohrenweiser and Backes-Gellner, 2010).

${ }^{7}$ For comparison, the median gross monthly wage for full-time employees subject to social security contributions (excluding trainees) was 3,209 euros in 2017 (BIBB, 2019).
} 
the 10 most popular professions accounted for approximately $45 \%$ of all new trainees from the academic school track in 2017, and among those, management assistant jobs (e.g., "industrial management assistant", "management assistant for wholesale and foreign trade") as well as IT jobs ("computer science expert") were especially favored (BIBB, 2019). Apart from a few exceptions, high school graduates from the non-academic track represent the minority in these professions (BIBB, 2019) and thus have low chances of obtaining these training positions. Consequently, a decrease in apprentice supply by graduates from the academic school track may lead to more relaxed competition for the most attractive apprenticeships - albeit only if firms do not withdraw from offering these positions in response to the lower educational levels available.

\subsection{The Bologna Process}

In 1999, 29 European countries agreed to harmonize their national higher education systems and create a coherent transnational system, the European Higher Education Area (EHEA). This so-called Bologna Process aimed at promoting European citizens' employability, competitiveness and mobility within the EHEA. At its core, a two-cycle higher education system (undergraduate and graduate) was introduced and accompanied by easily readable and comparable degrees as well as a common system of credits (Bologna Declaration, 1999) \& While in some countries (e.g., UK) only a mild restructuring was required, other countries, such as Germany, Italy and Portugal, had to undertake major reforms of their higher education systems (Neugebauer, 2015). In Germany, the established single-cycle system awarding either Diplom, Magister, or Staatsexamen was replaced by the new two-cycle system of consecutive BA and MA degrees.

This change in the structure of university education probably affected the post-secondary education decisions of high school graduates from the academic track. According to rational action theory (Breen and Goldthorpe, 1997), these decisions are determined by the expected costs and returns and the perceived probability of success $9^{9}$ In what follows, we argue that the Bologna Process altered the preconditions under which school leavers decide in favor of academic education by reducing study costs and emphasizing employability.

\subsubsection{Reduction in costs}

The Bologna Process shortened the regular study duration to obtain a first degree by approximately one-third from $4-5$ years to only $3-3.5$ years 10 The effective study duration

\footnotetext{
${ }^{8}$ At the Ministerial Conference Berlin 2003, the doctoral level was included as a third cycle in the new degree system.

${ }^{9}$ Expectations in turn are affected by preferences and abilities (e.g. Arcidiacono et al. 2012, Wiswall and Zafar, 2015). Further determinants are for instance family background (Björklund and Salvanes, 2011) and peer group effects (Bobonis and Finan, 2009).

${ }^{10}$ At the moment, approximately $94 \%$ of all BA programs at universities have a regular study duration of six semesters. At universities of applied sciences it is mostly six (33\%) and seven semesters (54\%) (HRK, 2019).
} 
was reduced even more as the median study duration for a BA degree was 7.1 semesters in 2017 compared to 11.5 semesters for a former university degree in 2000 (Destatis, 2018b). Apprenticeships and BA degrees now take about the same amount of time (see Section 2.1), and thus, direct study costs as well as opportunity costs to obtain a first university degree have decreased in relation to apprenticeships. According to a micro simulation model for Germany from 2012, average opportunity costs in the form of lost income amount to 18,200 euros per study year, compared to 6,500 euros for a dual apprenticeship (Pfeiffer and Stichnoth, 2015) 11

This argument is backed by empirical evidence on the impact of financial constraints and financial aid on university enrollment. Decreased enrollment due to tuition fees is widely reported in the Anglo-American context (e.g., Heller, 1997; Neill, 2009) and to a small extent in Germany (Dwenger et al., 2012; Hübner, 2012), where tuition fees are -if they exist at all - low and other studies cannot confirm their negative impact on enrollment (Helbig et al., 2012; Bruckmeier and Wigger, 2014). Conversely, tuition decreases and financial aid are found to increase college enrollment in the U.S. (e.g., Dynarski, 2003, Abraham and Clark, 2006, Cornwell et al., 2006, Denning, 2017) and - again, to a much lower extent - in Germany (Steiner and Wrohlich, 2012).

Ceteris paribus, the introduction of BA degrees may encourage more high school graduates from the academic track to choose a university education over an apprenticeship. This should particularly hold for students from non-academic backgrounds, as such students are believed to be more cost-sensitive (Peter and Zambre, 2017). Relatedly, the effects of the Bologna Process on apprentice supply may be particularly strong in those years and regions where there were tuition fees.

\subsubsection{Expected returns}

Firms sent out clear signals from the beginning that BA graduates could hope for good employment opportunities ${ }^{12}$ Therefore, the labor market prospects for BA graduates were assessed as very good at the beginning, although the true returns to a BA degree were unknown. For instance, the first reports on the labor market outcomes of new graduates for Germany were not available until 2011 (see, e.g., Briedis et al., 2011, Rehn et al., 2011, Schomburg, 2011). Recently, positive and-in relation to VET-higher individual returns to a university education in general (see Pfeiffer and Stichnoth, 2015, 2018, for Germany) and to BA degrees specifically (Neugebauer and Weiss, 2018) are documented. In terms of employment probabilities, however, vocational education seems to outperform university education at the early stages of the career due to higher skill specificity (Brunello and Rocco, 2017; Golsteyn and Stenberg, 2017, Hanushek et al.,

\footnotetext{
${ }^{11}$ Currently, there are no tuition fees in Germany. However, seven of 16 federal states introduced low tuition fees of up to 500 euros per semester between 2006 and 2007 and abolished them again between 2008 and 2014 (Thomsen and von Haaren-Giebel, 2016).

${ }^{12}$ See the "Bachelor Welcome!" initiative among leading German companies in 2004 (Neugebauer, 2015).
} 
2017) ${ }^{13}$ In line with these general comparisons, Neugebauer and Weiss (2018) report higher risks of unemployment for BA graduates from universities than for VET graduates, although not for BA graduates from universities of applied sciences. They explain this finding by appealing to the higher practical orientation and closer university-employer links at universities of applied sciences. However, even with available information on returns, students' individual beliefs and expectations can differ substantially. Among others, Oreopoulos and Dunn (2013) and McGuigan et al. (2016) show that the provision of information on costs and returns increases not only students' knowledge but also their likelihood of enrollment. Peter and Zambre (2017) report that for the low-tuition context of Germany, information provision on benefits increases college enrollment, particularly for students from non-academic families.

\subsubsection{Increase in perceived probability of success}

One of the major aims of the Bologna Process was to enhance the employability of university graduates. Although no clear targets have been set and no EHEA-wide curricula change has been implemented, a vast range of employability goals emerged from the public debate during the Bologna Process. These can be categorized into two major thrusts. First, the so-called key competencies were introduced into curricula to foster general competencies unrelated to the respective majors, such as rhetoric, presentation skills or foreign languages. Second, a strong focus was placed on practice-oriented learning to strengthen links between academia and (future) occupational tasks. For instance, the integration of practitioners as part-time lecturers was emphasized, and internships were made mandatory for a broad range of BA programs (Teichler, 2011). According to data from the recent Graduate Panel from 2013 by the German Centre for Higher Education Research and Science Studies (DZHW), 62\% of all BA graduates from universities and $76 \%$ of all BA graduates from universities of applied sciences had to complete at least one compulsory internship during their studies (Fabian et al. 2016 ). In contrast, of the 2001, 2005 and 2009 graduation cohorts, only 48\% of all former graduates completed a mandatory internship according to Margaryan et al. (2020). Hence, university education became more oriented towards labor market needs than before, which holds in particular for those universities where practical application was not stressed to the same extent as at universities of applied sciences (Witte et al., 2008).

These shifts in curricula from less theoretical to more practical content may have increased the perceived probability of success and induced some high school graduates from the academic track to go to a university instead of doing an apprenticeship.

\footnotetext{
${ }^{13}$ There is also some, albeit less consistent, evidence that this pattern reverses in the later stages of the career path (at around the age of 50), which is explained by the more general training of a university education that allows for greater flexibility and adaptability to technological change later on (Golsteyn and Stenberg, 2017, Hanushek et al. 2017). However, Brunello and Rocco (2017) cannot confirm the reversal of employment probabilities in the later stages of the career path in favor of university education.
} 


\section{Data}

To estimate the effect of BA degrees on regional apprentice supply, we combine data from different administrative sources for the observation period 1997 to 2011. First, we make use of the Sample of Integrated Labor Market Biographies (SIAB) to count new apprentices per region, occupational area and year. Second, we draw on data from the Federal Statistical Office of Germany (Destatis) to exploit region $\times$ area-of-study $\times$ year variation in first-year BA students. These data are merged on the level of 141 German regional labor markets defined by Kosfeld and Werner (2012), which have several advantages compared to counties: regional labor markets are delineated by commuter links and, therefore, represent homogeneous functional areal units that reflect actual economic conditions better than administrative units such as counties 14 It can be assumed that place of residence and place of work coincide within the same region. Moreover, between $64 \%$ (1997) and 82\% (2011) of all regional labor markets contain at least one university or university of applied sciences (see Figure A-2 in the appendix). Taking into account that apprentices are rather immobile (nine out of ten trainees stay in the county they live in or in neighboring counties (Jost et al., 2019)), these regions can be considered the primary search area for post-secondary education opportunities. This also holds for apprentices qualified for university, who are only slightly more mobile than the average apprentice (1.5 out of ten migrate beyond neighboring districts (Jost et al., 2019) $) .15$

\subsection{New Apprenticeships}

Information on new apprentices is obtained from the SIAB provided by the Institute for Employment Research (IAB) ${ }^{16}$ The SIAB is a representative $2 \%$ random sample of all employees subject to social security contributions in Germany and represents approximately $80 \%$ of the labor force in Germany, excluding, e.g., civil servants, soldiers, and the self-employed. Apprentices are generally subject to social security contributions and are therefore contained in the SIAB. They can be clearly identified by their employment status ("trainee"), and the data include detailed individual-level information such as sex, age, school leaving qualification, place of work at the county level and occupation (3-digit level). One limitation of the SIAB, however, is that it only allows us

\footnotetext{
${ }^{14}$ The definition of regional labor markets by Kosfeld and Werner $(2012)$ is comparable to local labor markets, which are used, for instance, in Autor et al. (2013) and Autor and Dorn (2013)

${ }^{15}$ Most university students in Germany also tend to enroll near to their home place (Dwenger et al. 2012. Haussen and Uebelmesser, 2018). Based on application data from the German central clearing house for the years 2002 to 2008, Dwenger et al. (2012) report a baseline probability of applying in the home state of $69 \%$. A similar size is found for graduates that studied in their home state by Haussen and Uebelmesser (2018) based on data from the DZHW Graduate Panel for the 2004/05 graduation cohort. In addition, distance to the nearest university affects enrollment decisions negatively (Spiess and Wrohlich, 2010).

${ }^{16}$ The data basis of this paper is the weakly anonymous Sample of Integrated Labor Market Biographies (SIAB) 1975 - 2014. The data were accessed on-site at the Research Data Centre (FDZ) of the Federal Employment Agency at the Institute for Employment Research (IAB) and/or via remote data access at the FDZ. See Antoni et al. (2016) for a detailed description of this data source.
} 
to observe actual apprentices and not those applicants who do not find an apprenticeship position. Since the actual apprentice supply can therefore not be measured, our estimates merely reflect the effects on filled apprenticeship positions resulting from successful matches.

To identify new apprentices, we follow the official definition of the Federal Statistical Office of Germany for newly concluded training contracts and count establishment entries of persons with the employment status "trainee" who do not drop out until the end of the same calendar year (Destatis, 2019). Hence, this definition includes not only new entrants into apprenticeships but also apprentices who change their training firm (excluding those in the same calendar year or in the second half of the previous year to avoid doublecounting) 17

The data on employment biographies (status and dates of employment, wages, etc.) are highly reliable, as reporting is mandatory and employers face penalties in cases of mis- or non-reporting. Unfortunately, this does not hold for information on school leaving qualifications, leading to missing values and inconsistencies. We correct these using one of the heuristic imputation procedures proposed by Fitzenberger et al. (2006), which reduces the share of missing school qualifications of new apprentices from approximately $15 \%$ to less than $1 \% 18$

Afterwards, we split the number of apprentices into highly and less-educated, i.e., those who come from the academic school track and are eligible for both the academic and the apprenticeship system and those who do not. We limit the observation period to the years 1997 to 2011 to avoid bias due to a change in reporting behavior. At the end of 2011, a new occupation code (KldB 2010) was introduced by the Federal Employment Agency that corresponds to the internationally acknowledged ISCO code. As a result, categories for the school leaving qualifications were also changed, and some firms adjusted their reporting, which led to a sharp increase in new highly educated apprentices. As shown in the following section, the selected time horizon still captures the full implementation of

\footnotetext{
${ }^{17}$ In contrast to Destatis, we are not able to identify follow-up contracts as long as they do not coincide with an establishment change. However, these do not play a major role and only amount to approximately $1.1 \%$ of all newly concluded training contracts in 2017 according to BIBB $(2019)$. This also applies to occupation changes.

${ }^{18}$ Since the imputation procedure 1 (IP1) by Fitzenberger et al. (2006) leads to the most plausible numbers (compared to official statistics), we report only the results for IP1. IP1 extrapolates education information to subsequent spells with missing or lower levels of education (forward extrapolation). Afterwards, education information from the first spell with non-missing information is extrapolated to previous spells with missing information until a certain minimum age limit is reached (backward extrapolation). Actually, this imputation rule was developed for the education variable in the former IABS. However, since the underlying heuristics are the same, we can easily employ it to the school leaving qualification in the SIAB by making a few adjustments. For instance, we set the minimum age for having at least a secondary general school certificate at 15 years and for having a higher education qualification to 18 years. Since IP1 tends to overreport true educational status (Hutter et al. , 2015), we check the robustness of our results by additionally using the other two imputation procedures (IP2A and IP3) as suggested by Fitzenberger et al. (2006), as well as the non-corrected information on school leaving qualifications. The more sophisticated procedures IP2A and IP3 extrapolate only spells that are considered valid, e.g., due to high-frequency reports of the same status. Using non-imputed numbers as well as the two other imputation rules (IP2A and IP3) does not alter the results shown in Section 5.1 significantly. These results are available upon request.
} 
the Bologna Process. Finally, we aggregate counts of new apprenticeships to the regional labor market level by place of work and distinguish between four different occupational areas: 1) "health, social work, education", 2) "business, trade, services", 3) "STEM", and 4) "other" (see Table A-1 in the appendix).

The aggregate numbers of apprentices by type of qualification obtained from the SIAB are depicted in Figure 2 and can be compared to the official (but less differentiable) numbers provided by Destatis ("Statistics of Vocational Training") to check their plausibility. Although slightly overstated, they are in line with official reports and follow the same patterns. As mentioned in Section 2.1, the supply of new highly educated apprentices increases steadily both in absolute and relative size. Conversely, the number of total new apprentices trends downwards in a fluctuating pattern, which is driven by the group of less-educated apprentices.

\section{$<$ Insert Figure 2 here $>$}

A couple of further plausibility checks are carried out on our data. The age distributions of total and highly educated new apprentices seem plausible and correspond to official numbers, although they are slightly overstated (total: mean age of 19.3 years compared to 18.8 years in BIBB (2019); highly educated: mean age of 21.8 years compared to 21.0 in 2017 in BIBB (2019) $) .19$ As usual, most new apprentices start in August or September (77\% of the total, $70 \%$ of the highly educated). Approximately $91 \%$ of the identified apprentices (95\% of the highly educated) are indeed new entrants, while the remaining consist of establishment changes or multiple apprenticeships. This corresponds very well to the average $89 \%$ reported in BIBB (2019).

Moreover, Figure 3 disaggregates the total number of new highly educated apprentices into the four different occupational areas for men (Panel A) and for women (Panel B). As is evident from the figure, most of both males and females go into business occupations, such as "industrial management assistant" or "management assistant for wholesale and foreign trade". This group appears to have a rather cyclical pattern of entrance behavior. For males, STEM occupations represent the second largest group and have become increasingly important (1997: 18\%; 2011: 23\%). In contrast, new highly educated female apprentices in STEM occupations remain at a rather low level without showing major changes. The second largest occupational area for females, however, is "health, social work, education", but the supply of female apprentices in this area exhibits declines in absolute and relative size. Finally, the occupational area "other" consists of occupations in handicraft or low-tech services and is of only marginal importance for highly educated apprentices.

\footnotetext{
${ }^{19}$ Since we have only information on the year of birth, the age of new apprentices can only be calculated on a yearly basis. The actual average age is therefore higher than the calculated age. This procedure corresponds to the age calculation in BIBB (2019). However, until 2006, all new apprentices in the lower and upper age groups are included in the average age calculation of BIBB $(2019)$ at 16 and 24 years respectively. This may explain the differences in the average age between the two data sets to some extent.
} 


\section{$<$ Insert Figure 3 here $>$}

\subsection{Expansion of First-year BA Students}

To capture the regional and temporal variation in the introduction of BA degrees, we use administrative data from the Federal Statistical Office of Germany (Destatis) on all first-year students at publicly acknowledged universities ("Statistics of Students"). ${ }^{20}$ Although at an aggregated level, it allows us to make distinctions by sex, nationality, field of study and type of degree studied for. These data are collected for each university in academic years (summer term plus the following winter term).

We focus on universities and universities of applied sciences, and drop other types of universities according to the classification of Destatis, such as colleges of theology, colleges of art and music, colleges of education and colleges of public administration. ${ }^{21}$ Degrees from these schools are either not affected by the Bologna Process (see church and teacher examinations) or direct students towards specific labor markets (civil services). Correspondence colleges are excluded because they do not require on-site presence and first-year students are not located in a specific region. Then, we assign every university to one of 141 German regional labor markets and aggregate first-year students accordingly. Moreover, the 62 fields of study are collapsed into five different areas of study: (1) "humanities", (2) "health, social work, education", (3) "economics", (4) "STEM", and (5) "other", which contains the remaining fields of study, such as other social sciences or agricultural, forest and food sciences (see Table A-2 in the appendix).

Panel A in Figure 4 shows the share of first-year BA students to the total number of first-year students studying for a BA or a former degree, which represents the rate of implementation of the new degree system and gives a first insight into its regional, temporal and area-of-study variation (see also Table A-3 and Figure A-3 in the appendix). As is evident from the figure, the replacement of former degrees by the new BA degrees in Germany took a fairly long time, lasting for a period of approximately 12 years and following an S-shaped pattern. In the first years, there were only a few early adopters (in particular, private institutions) that shifted to the new system. Afterwards, implementation accelerated, and most of the transition took place between 2004 and 2008. In those years, differences in implementation between regions peaked and later declined as late adopters caught up. Finally, there were no additional major changes after approximately $90 \%$ of the overall implementation, and a regional average implementation rate of $93 \%$ was reached in 2012. On the aggregate level, the Bologna Process is thus

\footnotetext{
${ }^{20}$ Our data set combines a special evaluation provided by Destatis for the years 1997 to 2004 with an evaluation obtained from the ICE database of science and education departments in the state ministries for the years 2005 to 2014. Both evaluations are based on the "Statistics of Students".

${ }^{21}$ We also include the so-called Gesamthochschulen in North Rhine-Westphalia. Since they were transferred into universities in 2003, we handle them accordingly. All in all, our sample covers approximately $94 \%$ of all first-year students in 2011.
} 
now finished - aside from the mentioned exceptions in law, medicine, and pharmacy.22 Looking at the five areas of study separately, we do not find any striking differences, even though programs in "humanities" and "others" switched relatively early while programs in "economics" and "health, social work, education" switched relatively late. Moreover, engineering and, to a lesser extent, economics show more outliers at the end of the implementation period.

\section{$<$ Insert Figure 4 here $>$}

Next, we examine the absolute number of first-year BA students (see Panel B in Figure 4). After a slow start, the expansion of first-year BA students accelerated, and the average region already reached considerable case numbers in 2006, with approximately 1,000 first-year BA students in total. In 2011, the absolute numbers peaked for most areas of study and remained rather stable in the following years. In contrast to the share of first-year BA students, differences in the absolute number of first-year BA students per region increased steadily until the end of the observation period (see Panel B in Figure 4 and Table A-4 in the appendix). Among the five areas of study, STEM accounts for approximately $40 \%-50 \%$ of all first-year BA students in our sample and economics for about one fourth-both slightly declining in recent years (see Figure 5). In contrast, "health, social work, education" is becoming increasingly important and amounted to approximately $14 \%$ of all first-year students in 2017.

\section{$<$ Insert Figure 5 here $>$}

\section{Empirical Strategy}

\subsection{Identification Approach}

For identification, we employ a generalized difference-in-differences (DiD) approach that exploits regional and temporal variation in reform adoption 23 In our case, variation arises from the specific institutional context of the reform: while the federal states agreed upon common structural guidelines for the implementation of the reform (e.g., length, profile types of new programs), they could set the actual legislation on the scope of implementation individually. For instance, some federal states (such as Bavaria) never abolished state examinations for teaching degrees, while others (such as Saxony) never

\footnotetext{
${ }^{22}$ However, some regions (14 out of 116 university regions) still remained at a relatively low implementation level of less than $80 \%$ in 2014 . These regions either contain universities that are dominated by the less-affected law and medicine courses (e.g., Heidelberg, Passau) or are located in East Germany, such as Dresden or Halle, where Diplom studies are still possible and are quite noticeably demanded. For instance, in Dresden in 2017, first-year students studying for former degrees still amount to approximately 2,115 or $44 \%$ of all first-year students studying for a BA or a former degree.

${ }^{23}$ Similar approaches can be found in, e.g., Berlinski et al. (2009), Havnes and Mogstad (2011), Bauernschuster et al. (2016), and Sandner and Thomsen (2020) in the context of child care reforms, Ruhose et al. (2020) in the context of a partial retirement reform and elderly learning and Cantoni et al. (2017) in the context of evaluating the effects of a school curricula reform on students' political attitudes in China.
} 
completely abolished Diplom degrees. However, at a lower hierarchical level, universities were allowed high levels of autonomy and could freely decide on the timing of the implementation of the new program structure, as long as it was completed by 2010 (Alesi et al., 2005). As a result, there were large differences in the reform adoption between universities as well as between departments within universities during this transition period (see, e.g., the case of the HU Berlin in Hahm and Kluve, 2019).

Although some departments intentionally accelerated or delayed the introduction of the new program structure, we argue that the timing of the transition can be considered exogenous from the point of view of school leavers who face post-secondary education decisions in a certain regional labor market. According to the official implementation guidelines for universities, new study programs were usually announced no earlier than a year in advance (HRK, 2004). Hence, there was little leeway for anticipation effects, and we can exploit the introduction of BA degrees as a natural experiment that caused regional and temporal variation in the number of first-year BA students. This generalized form of a DiD estimator can be written as follows:

$$
y_{r, t}=\theta B A s t u d_{r, t}+\mathbf{X}_{r, t}^{\prime} \beta+\alpha_{r}+\delta_{t}+t \times \alpha_{r}+\epsilon_{r, t}
$$

where $y_{r, t}$ is the selected outcome of interest in region $r$ at time $t$, and $B A s t u d_{r, t}$ is the number of first-year BA students in region $r$ at time $t \in(1997-2011)$. Region fixed effects $\left(\alpha_{r}\right)$ and year fixed effects $\left(\delta_{t}\right)$ are included to account for unobserved timeinvariant heterogeneity between regions and for unobserved time effects that affect all regions equally. In our most preferred specification, we additionally allow regions to follow different individual trends over time $\left(t \times \alpha_{r}\right)$. $\mathbf{X}_{r, t}$ represents a matrix of covariates that controls for time-variant factors that may influence the outcome variable of interest. We will explain the rationale behind the choice of these controls below. Since our outcome $y_{r, t}$ is a count variable (the number of new apprentices), we use a fixed effects Poisson estimator (Wooldridge, 1999). Robust standard errors are clustered at the level of regional labor markets $\left(\epsilon_{r, t}\right)$.

In a second estimation, we investigate occupational heterogeneity and differentiate apprentices by four occupational areas and first-year BA students by five areas of study. Then, we run separate regressions for all $(4 \times 5)$ combinations using the following specification:

$$
y_{r, o, t}=\theta B A s t u d_{r, s, t}+\mathbf{X}_{r, t}^{\prime} \beta+\alpha_{r}+\delta_{t}+t \times \alpha_{r}+\epsilon_{r, t}
$$

where $y_{r, o, t}$ is the selected outcome of interest in region $r$ for a certain occupational area $o \in($ health/socialwork/education, STEM, business, other) at time $t$, and 
$B$ Astud $_{r, s, t}$ is the number of first-year BA students in region $r$ in a certain area of study $s$ $\in$ (humanities, health/social work/education, STEM, economics, other) at time $t^{24}$

The main group of interest is highly educated apprentices coming from the academic school track who are eligible for both a university education and apprenticeship training. Since we do not have individual-level data on educational choices and cannot observe whose post-secondary education decision is affected by the introduction of BA courses, we interpret the estimated coefficient $\theta$ as an ITT. It represents the equilibrium effect of BA degrees on highly educated apprentice supply, including potential peer externalities such as higher/lower competition for training or study places (see, e.g., Baker et al., 2008). Following Baker et al. (2008) and Havnes and Mogstad (2011), the ITT can be scaled by the probability of treatment to obtain an ATT. In our case, this would be the share of school leavers who are still undecided half a year before leaving high school.

\subsection{Selection of Covariates}

By using region fixed effects, the speed and scope of the implementation of BA degrees does not need to be unrelated to characteristics of the regional labor markets as long as they remain stable across the observation period. However, if these regional characteristics change over time and are correlated with the number of new apprentices, our empirical results would be biased. Therefore, we include a set of control variables covering supplyand demand-side effects. We consider the log number of school leavers as well as the share of school leavers with university entrance qualifications as supply controls to account for different trends in the cohort size and composition of school leavers. For instance, demographic changes and educational expansion with respect to the size and qualification of high school graduate cohorts may affect regions very differently. Furthermore, educational reforms, such as the G8 reform, have created external supply shocks for some federal states in some years that temporarily affect the competition for training places. ${ }^{25}$ To capture different migration trends in the group of interest, we further include the share of the population aged 18 to 25 years.

On the demand side, we use the unemployment rate to cover macroeconomic conditions that may negatively affect firms' demand for training (Brunello, 2009; Bellmann et al. 2014, Lüthi and Wolter, 2020). In addition, there is evidence that business cycles affect formal schooling decisions countercyclically (Méndez and Sepúlveda, 2012). Moreover, the share of persons in employment in the industry sector should control for regional differences in the contraction of that sector. Finally, we use the share of firms with more than 250 employees as a further demand-side control for available training positions

\footnotetext{
${ }^{24}$ The asymmetry of occupational areas and areas of study is explained by the fact that they are not one-to-one comparable. For instance, there are essentially no apprenticeships in humanities due to the lack of a practical orientation.

${ }^{25}$ The $G 8$ reform reduced mandatory time to obtain a university entrance qualification from 13 to 12 years. It was implemented by most German federal states between 2001 and 2008, leading to double cohorts in several years (the simultaneous graduation of cohorts within 12 and 13 years).
} 
(Kleinert and Kruppe, 2012). An overview of all included variables, their definitions and sources is given in Table A-5 in the appendix.

\subsection{Plausibility of the Identifying Assumptions}

To identify $\theta$ as the causal effect of BA degrees on new apprentices, we assume that-conditional on region and year fixed effects as well as controls - labor market regions would have followed the same trend in new highly educated apprentices in the absence of the Bologna Process. One major concern, however, may be that there are still systematic regional differences, e.g., between regions with and without universities or between regions with large and with small universities. Relatedly, BA programs may have expanded, especially in those regions where technological progress leads to a high demand for highly qualified labor. Hence, the expansion of BA degrees may not be exogenous to new apprentices. To investigate this, we regress first-year BA students on several regional covariates and condition on region and year fixed effects (column 1 in Table 1). Moreover, we predict early, mid, and late strong BA expansion (above-median number of first-year BA students in 2005, 2008, and 2011) using pre-treatment regional characteristics in 1999 (columns 2 to 4 in Table 1).

\section{$<$ Insert Table 1 here $>$}

As the table shows, we cannot reject the null hypothesis of no joint influence of regional characteristics on the number of first-year BA students or on the timing and scope of the expansion. Indeed, several regional covariates are significantly correlated with first-year BA students or the timing of expansion. However, they are consistent with expected differences in size (e.g., school leavers, population density) and the composition of university and non-university regions (e.g., age and qualification distribution). Therefore, we believe that they are not a threat to our identification strategy. In fact, by performing an event-study analysis, we can further support the plausibility of the common trend assumption. Figure 6 plots the event study estimates from a distributed lag model following Schmidheiny and Siegloch (2020) with an effect window of three leads and one lag, allowing for multiple events with varying treatment sizes.26 The short effect

${ }^{26}$ This event study is estimated as specified in Schmidheiny and Siegloch $(2020)$ :

$$
y_{r, t}=\sum_{j=\underline{j}}^{\bar{j}} \theta_{j} B A s t u d_{r, t}^{j}+\alpha_{r}+\delta_{t}+\epsilon_{r, t},
$$

where the effect window is restricted to $\bar{j}$ periods after and $\underline{j}$ before the event and where the binned treatment variables $B$ Astud $d_{r, t}^{j}$ are generated by

$$
B A s t u d_{r, t}^{j}= \begin{cases}\sum_{s=-\infty}^{\underline{j}} \Delta x_{r, t-s} & \text { if } j=\bar{j} \\ \Delta x_{r, t-j} & \text { if } j<\bar{j}<\bar{j} \\ \sum_{s=\bar{j}}^{\infty} \Delta x_{r, t-s} & \text { if } \bar{j}=\bar{j} .\end{cases}
$$


window is chosen in correspondence to our relatively short observation period of 15 years. In addition, we do not expect any major treatment effect dynamics, as the effect of an increase in first-year BA students on new apprentices should materialize in the same year. As shown in Figure 6, the pre-trends are reasonably flat and never statistically significantly different from zero at the $5 \%$ level, which supports the identifying assumption. In year 0 , we find a clear negative and significant effect amounting to approximately $-9 \%$. One year later, the cumulative effect decreases to $-6 \%$. Including region-specific linear time trends further flattens the estimates and reveals a clearer picture of no pre-trend and a stable negative post-treatment effect without any sign of a delay, fade-out or push-back of the effects later on.

\section{$<$ Insert Figure 6 here $>$}

Nevertheless, to take this potential endogeneity issue seriously, we run different specifications where we stepwise include 1) only region and year fixed effects, 2) the time-varying regional characteristics explained previously and included for theoretical reasons, and 3) region-specific linear time trends, which gives our most preferred specification (see equation (1)) in the empirical analysis below. In addition, we check the robustness of the results by 1) excluding non-university regions and 2) adding the remaining covariates from the balancing test as further controls (see Section 5.3).

Another concern may be a potential violation of the stable unit treatment value assumption (SUTVA) through spillovers between regions. However, since we use regional labor markets based on commuter links and apprentices are a rather immobile group, most of the school leavers likely search for an apprenticeship inside their region of residence (see Section 3). Thus, it seems plausible to assume that those high school graduates from the academic track who are deciding between an apprenticeship and a university education are only affected by the expansion of BA courses within their region of residence. In this case, the SUTVA should hold.

We can also rule out further forms of self-selection. It seems very unlikely that students selected into certain school tracks, advanced/delayed their timing of graduation from high school or moved between regions in order to benefit from or avoid treatment. To provide some checks for this, we regressed the size and share of high school graduates from the academic track as well as the share of the population aged 15 to 18 years on future first-year BA students. None of the coefficients are significant (see Table A-6) ${ }^{27}$ Nevertheless, we exclude the early period of the Bologna Process (2000-2004) as a robustness check to investigate the sensitivity of our results to selective study choices.

\footnotetext{
${ }^{27}$ In addition, it is highly improbable that some regions slowed down the expansion of BA courses, in order to, say, protect their dual apprenticeship system, as these regions represent functional units and their administrative power is thus quite limited. The non-significant effects of the log number of trainees per 1,000 employees in the balancing test and the expansion prediction also suggest no sorting of regions with a strong apprenticeship system into early, mid or late strong expanding regions (see Table 1).
} 


\section{Results}

\subsection{Baseline Results}

Panel A in Table 2 presents estimates of the average regional impact of first-year BA students on new highly educated apprentices using equation (1). In column (1), we only include region and year fixed effects. Column (2) additionally introduces covariates, and column (3) adds region-specific linear time trends allowing every region to follow a different trend in the number of new highly educated apprentices.28 As shown, all coefficients are negative, but their size varies depending on the specification. While we find a small and not statistically significant effect at the $5 \%$ level in the first two specifications, the estimate doubles and becomes highly significant once we allow every region to follow an individual linear time trend. This indicates that regions with a strong BA expansion show a steeper pre-trend in new highly educated apprentices than those with a weak expansion, which could place doubts on the exogeneity of the intervention. However, since the pre-trends are reasonably flat and we do not find any evidence of a lagged treatment effect, we are confident in interpreting this result as causal. The estimated effect implies that the average regional expansion of first-year BA students during our observation period $(+2,628$ from 1997 to 2011) led to a decrease in new highly educated apprentices by approximately $3 \%-5 \%$ on average, which corresponds well to the estimates obtained from the event-study analysis above. In absolute terms and scaled to account for the total population, a 3\%-5\% decrease translates into an overall reduction in new highly educated apprentices of between 3,500 and 5,900 in 2011 compared to the counterfactual of no Bologna reform.

\section{$<$ Insert Table 2 here $>$}

Panels B and C in Table 2 show separate estimates for males and females ${ }^{29}$ As can be seen, we find substantially to slightly larger negative and significant effects for males. The coefficient for males is very robust to the different specifications and is stable around $-5 \%$. In contrast, the coefficient in the female sample is - although also negativeconsiderably smaller and at most weakly significant. Thus, we interpret the negative effect on the total sample as mainly driven by males. In line with the descriptive evidence from Figure 3 in Section 3.1, this finding suggests that males and females go into very distinct apprenticeship markets, for instance, due to different occupational preferences that are affected differently by the Bologna Process.

\footnotetext{
${ }^{28}$ Here and henceforth, all specifications including region-specific linear time trends are estimated in Stata using the command ppmlhdfe to absorb the large number of fixed effects and obtain convergence (Correia et al. 2019a b).

${ }^{29}$ All gender separated regressions use gender-specific numbers of apprentices, first-year students and school leavers. Apart from that, the specification remains the same.
} 


\subsection{Effect Heterogeneity}

\section{a) Occupational subgroups}

To investigate this potential occupational heterogeneity in more detail, we distinguish the number of new apprentices by four occupational areas and the number of first-year BA students by five areas of study. We run separate regressions for all $4 \times 5$ combinations using equation (2) to look at both vertical shifts in educational attainment (e.g., STEM major instead of STEM apprenticeship) and diagonal shifts (e.g., business major instead of STEM apprenticeship). The 20 estimated coefficients are reported in Figure 7 and are already scaled to the respective average increase in first-year BA students until 2011 to ensure comparability between areas of study ${ }^{30}$ Estimates marked by circles are obtained from a specification that includes only region and year fixed effects, estimates marked by diamonds add regional controls, and estimates marked by squares additionally include region-specific linear time trends.

\section{$<$ Insert Figure 7 here $>$}

Although many of the coefficients are insignificant, there are some significant effects for certain combinations. Regarding STEM occupations, we find strong negative effects of first-year BA students on new highly educated apprentices, which are driven in particular from the linked STEM majors but also from economics studies. These estimates are very robust to adding controls and including region-specific linear time trends. They indicate that the average regional expansion in first-year BA students in STEM (economics) reduced the number of new highly educated apprentices in STEM occupations by $9 \%$ $(-6 \%)$ in our preferred specification. Furthermore, we find robust negative effects of first-year BA students in "other" majors (e.g., "social sciences, excluding economics") on the number of new highly educated apprentices in business occupations. However, at $-3 \%$, it is less strong of an effect than those for STEM occupations. Moreover, there is also some evidence for a negative effect of "health, social work, education" majors on business occupations that amounts to approximately $-3 \%$, although including trends drives the p-value of the coefficient slightly above the $5 \%$ threshold. Finally, with respect to occupations in "health, social work, education" and in "other" fields, we do not find any robust significant effects.

The identified gender heterogeneity could indicate that occupational pathways were affected differently by the introduction of BA degrees. For instance, the large negative effects on STEM occupations would suggest that technical apprenticeships are more prone to competition from BA degrees than other occupations. This would be surprising, insofar as Horstschräer and Sprietsma (2015) indeed found negative effects of the introduction of BA degrees on enrollment in electrical and mechanical engineering majors (albeit positive

\footnotetext{
${ }^{30}$ Detailed regression results are provided in Tables $\mathrm{A}-7$, $\mathrm{A}-8$ and $\mathrm{A}-9$ in the appendix.
} 
effects in computer sciences). However, our results show that the competition is not only between linked areas but also between areas not directly related (such as economics majors and STEM occupations).

\section{b) Gender heterogeneity}

As a next step, we investigate gender heterogeneity and estimate the regression models separately for males and females (see Panel A and Panel B in Figure 8). Focusing on STEM occupations first, we find that the negative effects reported in the total sample are driven in particular by men, whereas there are somewhat positive, but mostly insignificant, effects for women. The estimates suggest that the number of male first-year BA students in STEM, economics and "health, social work, education" majors affect the number of new highly educated male apprentices in STEM occupations negatively by $11 \%, 11 \%$ and $7 \%$, respectively - already scaled to account for the average regional BA expansion in the respective area of study. In contrast, there is some evidence of positive effects on new highly educated female apprentices in STEM occupations, driven by female first-year BA students in "other" majors and humanities. The former amounts to a positive effect of $9 \%$ in the most preferred specification, while the latter is only significant in the first two specifications. However, with only $5 \%$ of all new highly educated apprentices in 2010, STEM represents a rather small group for females compared to the $25 \%$ for males.

\section{$<$ Insert Figure 8 here $>$}

Furthermore, the negative effects on business occupations seem to be driven by females. Remarkably, the clearest effect comes from what are, at first sight, less related areas. We estimate that female first-year BA students in "health, social work, education" majors reduce the number of female highly educated new apprentices in business occupations by $4 \%$ - already scaled to account for the average regional BA expansion in the respective area of study. Moreover, we find some, albeit less robust, evidence for negative effects induced by economics majors $(-4 \%)$ and humanities $(-3 \%)$. For males, however, we report almost no significant effects on apprenticeships in business occupations across all specifications. In addition - consistent with the results from the total sample - we do not find any robust significant effects on "health, social work, education" occupations for either men or women. Finally, the effects on the marginal group of other occupations (handicraft, low-tech services) seem to be more negative for men than for women, even though none is very robust nor consistently signed.

\section{c) Interpretation}

Since gender differences persist on the level of the occupational subgroups, the heterogeneous results suggest that very specific types of school leavers were affected by the Bologna Process: first and foremost, men who are likely to take technical apprenticeships 
and, to a smaller extent, women who are likely to take business apprenticeships. This could indicate that the attractiveness of these professions declined disproportionately in favor of a university education. One possible channel may be that men with preferences for STEM now assess their probability of success at university more highly than they had done before. This is supported by the literature documenting gender gaps in STEM subjects and in self-assessments. Specifically, Cimpian et al. (2020) show that - based on a longitudinal student survey in the U.S.- - less able women tend to refrain from studying STEM majors, while men do not show this kind of hesitant behavior. Similarly, Lörz et al. (2011) find for Germany that male school leavers from the academic track assess their individual chances of success at university significantly more highly than females - conditional on identical performance in secondary school. Another explanation for the gender heterogeneity (and especially the opposite-signed effects in STEM occupations) could be different responses to changes in competitive pressure. As studies on double high school graduation cohorts show, greater competition increases the performance of males relative to females Ors et al. 2013; Morin, 2015), while the educational attainment of females tends to decrease or is delayed (Meyer and Thomsen, 2016; Meyer et al., 2019). In our context, this could suggest that women may refrain from studying, especially in those majors where more men study, and would benefit from less competition for specific apprenticeship occupations, such as in STEM fields.

Furthermore, differentiating the number of first-year BA students by areas of study reveals not only an increase in educational attainment (upgrading) but also some adjustments in major choice. For instance, the decrease in new highly educated male apprentices in STEM occupations is caused by an increase in first-year BA students in STEM, economics and "health, social work, education" majors. In addition, new highly educated female apprentices in business occupations seem to be sensitive to a rise in first-year BA students in "humanities", as well as in other majors, but not in economics.

\subsection{Robustness Checks}

\section{a) Unobserved heterogeneity}

To check the validity of our results, we run several robustness checks. First, we address concerns regarding unobserved heterogeneity. For instance, those regions with a high expansion in first-year BA students may have also experienced a stronger increase in labor demand for high-skilled workers and, thus, a stronger increase in the demand for highly educated apprentices. Moreover, it could be the case that the most dynamic university regions are particularly affected by urbanization trends and the in-migration of specific population groups (e.g., females, foreigners), which could result in upward trends in the apprentice supply. Therefore, we 1) exclude non-university regions and 2) add the remaining covariates from the balancing test as further controls (see Section 4.3). As shown in Table 3 , the baseline estimates remain rather stable and significant. To be 
precise, excluding approximately $20 \%$ of the observations increases the size and standard errors of the coefficients simultaneously in most of the specifications. The same holds for the occupation-specific effects shown in Figure A-4 in the appendix (estimates marked by squares). The large negative effects on STEM occupations for males and the modest negative effects on business occupations for females seem to be supported.

\section{$<$ Insert Table 3 here $>$}

Moreover, neither the baseline results nor the effects for the occupational subgroups are changed considerably by including additional controls that account for differential trends in labor demand and migration patterns, such as (i) the log GDP per capita, (ii) the share of employees subject to social security contributions with academic qualifications, (iii) the log population density, (iv) the share of females in the population and (v) the share of foreign-born residents in the population (see Table 4 below and estimates marked by diamonds in Figure A-4 in the appendix). Therefore, we are confident that our results are not driven by systematic and unobserved heterogeneity.

\section{$<$ Insert Table 4 here $>$}

\section{b) Falsification tests and placebo treatments}

Second, we perform a couple of falsification tests and use the number of less-educated apprentices as the group that should be rather unaffected by the introduction of BA degrees unless there are externalities, e.g., through higher or lower competition. As shown in Table 5, most of the coefficients are positive but are close to zero and never statistically significantly different from zero, which supports our empirical design and the previous findings. The same patterns are observed with respect to occupational heterogeneity (see Figure A-5 in the appendix), as none of the coefficients reveals a consistent or robust effect. This would indicate that the competition for training places was not relaxed for the less-educated to a significant extent and that the substitutability between less- and more-educated apprentices is therefore limited.

\section{$<$ Insert Table 5 here $>$}

In addition, we use first-year students studying for teaching certificates as well as those studying for former degrees as placebo treatments (see Figure A-6 in the appendix). While the former should be close-to-zero (because we expect little dependency between apprenticeships and teaching apart from the occupational area "health, social work, education"), the latter should point in the opposite direction than for first-year BA students. Indeed, none of the coefficients for first-year male students studying for teaching certificates are significant, and only one female area of study ("health, social work, education") has significant effects. In addition, most of the coefficients for first-year 
students studying for former degrees are also insignificant. However, for males, the negatively affected occupational area, STEM, shows some positive coefficients with respect to former-degree students. Again, this supports our interpretation of the results.

\section{c) Selective study and major choice}

Third, we investigate whether selective study and major choice drive our results. If effective, we should see changing estimates depending on the choice of the observation period. A deliberate selection into treatment was only conceivable at the beginning of the Bologna Process when there were considerable options for former degrees. Therefore, we exclude the early period of the Bologna Process (2000-2004) and estimate equations (1) and (2) again 31 As shown in Table A-10 in the appendix, the coefficients - though slightly larger - remain stable in most of the specifications. The negative effects in the total sample are strongly supported, as are the non-significant effects for women. The negative effects on new highly educated male apprentices, however, are only confirmed for the first two specifications. However, the model fit is substantially reduced in the last specification indicating that the trends could not be precisely estimated when excluding the early period of the Bologna Process.

\section{d) Tuition fees}

Finally, we check the possibility of a confounding effect from the introduction and abolishment of tuition fees (see Section 2.2.1). For instance, if first-year BA students increased, especially in those regions where tuition fees were not introduced (or were abolished), the estimated negative effect on apprentice supply would not be driven solely by the introduction of BA degrees but also by tuition fees. Therefore, we interact our treatment variable with a dummy indicating whether tuition fees were in place in a certain region in a certain year. As shown in Table A-11 in the appendix, the negative effect of first-year BA students remains significant and negative across the different specifications - either solely or in interaction with tuition fees.

The same holds for the male sample in Panel B. Tuition fees heavily reinforce the negative effect of first-year BA students - more than twice the baseline effect without tuition fees. However, including region-specific linear time trends seems to pick up most of the interaction effects, which could indicate that it confounds the reforms of tuition fees and treatment effect dynamics. This supports our interpretation of the results so far and points towards the effectiveness of the channel "reduction in study costs", as school leavers seem to have switched especially to BA courses in those regions and years with tuition fees in effect. The effect is surprisingly strong, though, considering the low tuition fees of only 500 euros per semester.

\footnotetext{
${ }^{31}$ Note that the years 1997 to 1999 are still included to extrapolate the pre-treatment trends into the posttreatment period.
} 


\section{Discussion}

\subsection{Magnitudes of the Effects}

As mentioned in Section 4.1, we interpret the estimates as an ITT, which is an informative figure for policy evaluation because it gives the overall change in apprentice supply regardless of whether the assigned treatment was actually taken or not. However, to design policies that aim to foster apprenticeships or enhance university enrollment, it would be insightful to know the ATT, i.e., the effect on those who are actually affected by the Bologna Process in their post-secondary education decisions. For instance, some school leavers would have gone to university (always-takers) or would have done an apprenticeship (never-takers) regardless of the introduction of BA degrees. Therefore, we approximate a potential ATT by scaling the ITT with the share of school leavers who have made neither a firm decision to study nor one to train, namely, $17 \%$ according to Schneider and Franke (2014) ${ }^{32}$ Thus, an approximate ATT would be between $-18 \%$ and $-29 \%$ in the total sample and $-29 \%$ for males. As expected, the effect is quite large. It represents the effect on a very specific group of school leavers who are indecisive half a year before graduation. For this group, changes in incentive structures matter most, and the Bologna Process had a strong impact on educational decisions.

\subsection{Cost-benefit Analysis}

The presented empirical findings may have important consequences for economic, individual and fiscal returns to education. First, a reduced supply of highly educated apprentices aggravates the skills shortage in Germany, as apprenticeship training helps to reduce the number of unfilled qualified jobs (Bellmann and Hübler, 2014). In 2018, a record high of $10 \%$ unfilled training places was reported (BIBB, 2019), indicating that firms are increasingly facing problems in finding adequately qualified apprentices. Moreover, recent labor market projections show that the labor demand for skilled workers with completed VET will not decline but will even increase marginally in the near future (Maier et al., 2015). Other projections for the European Union, such as the CEDEFOP skill forecast, show a modest decline in demand for medium-skilled workers until 2030 (CEDEFOP, 2018). However, due to the labor market exit of the baby boomers, the replacement demand for medium qualifications until 2030 is still substantial $(57 \%$ as a proportion of the 2016 employment level (CEDEFOP, 2018)). Therefore, the skills shortage is considered to be one of the major threats to future economic development. For instance, non-scientific estimates indicate that it already costs German medium-sized companies up to 65 billion euros in turnover or $2.2 \%$ relative to GDP per year $(\mathrm{PwC}$, 2018). The overall net welfare loss, however, depends on whether the lack of skilled

\footnotetext{
${ }^{32}$ The $17 \%$ are calculated as the average of the three waves $(2006,2008,2010)$ of the DZHW Panel Study of School Leavers with a Higher Education Entrance Qualification that are available across our observation period.
} 
workers with completed VET can be replaced by university graduates, e.g., the new BA graduates, and on the external effects arising from a higher stock of knowledge capital (Hanushek and Woessmann, 2015).

Second, with respect to expected individual returns to education, there may be adverse impacts at different stages of one's career. Since VET graduates generally have higher employment probabilities in the early stages of their career than university graduates (Brunello and Rocco, 2017; Golsteyn and Stenberg, 2017, Hanushek et al., 2017), young labor market entrants may encounter greater difficulties in finding adequate jobs initially. However, over the life cycle, university graduates typically recoup their relative losses and earn substantially more than VET graduates, which amounts to an estimated average net gain in lifetime earnings between 151,000 (OECD, 2014) and 420,000 euros (Pfeiffer and Stichnoth, 2015).33 The individual net return to a university education compared to VET, however, depends very much on wage adjustments due to a higher supply of university education, shifts in the skill distribution of new and old graduates as well as the quality of their job matching. For instance, if firms replace the missing apprentices with BA graduates doing the same job for the same wage, individuals would experience a decline in the individual net return to education.

Finally, the lower supply of highly educated apprentices also has fiscal implications. The net average fiscal return to a university graduate (5 years) compared to a VET graduate (4 years) in 2012 is estimated at between 100,000 euros (Pfeiffer and Stichnoth, 2015 ) and 130,000 euros (OECD, 2014) ${ }^{34}$ Our estimate of a total decrease in highly educated apprentices of between 3,500 and 5,900 in 2011 due to the Bologna Process would result in a total reduction in new highly educated apprentices by 16,600 to 27,600 over the whole observation period. Hence, the total net fiscal gain would amount to approximately 1.66 to 3.59 billion euros over the whole observation period, assuming that all high school graduates actually go to university instead of doing an apprenticeship and that drop-out rates for both pathways are the same (VET entry cohort 2012: 24\% BIBB, 2019); university entry cohort 2012/13: 28\% (Heublein and Schmelzer, 2018)). Of course, these figures have to be interpreted with care since there are a number of mitigating effects possible. If, e.g., fiscal returns for highly educated apprentices are larger than the average reported by Pfeiffer and Stichnoth (2015) and OECD (2014), the net fiscal gain would be smaller. The same holds for the case where less-educated apprentices fill the gap in highly educated apprentices at least partially and their counterfactual is no

\footnotetext{
${ }^{33}$ Both individual net returns are estimated as the difference in the net present values of returns and costs based on typical educational and employment biographies. While Pfeiffer and Stichnoth (2015) use a discount rate of $1.5 \%$, OECD (2014) gives more weight to present values (3\% discount rate). This and further methodological differences, such as dealing with the variety of the German transfer system, can account for the large differences in individual net returns obtained (Pfeiffer and Stichnoth, 2015). Note that the value given for the OECD was calculated by the authors as the average of the value for men (197,000 euros) and for women (63,000 euros).

${ }^{34}$ Both fiscal net returns are estimated similarly to the individual returns described before, from a public sector perspective only. The value given for the OECD was again calculated as the average of the value for men $(211,000$ euros) and for women (92,000 euros).
} 
post-secondary education. Thus, our back-of-the-envelope calculation can be considered an upper-bound estimate of the overall effect and should be interpreted with care.

\section{Conclusion}

We have evaluated the effect of the introduction of BA degrees on the regional supply of highly educated apprentices. Our empirical estimates show that the reform challenged the dual apprenticeship system, as more high school graduates from the academic track decided against apprenticeships ( $-3 \%$ to $-5 \%$ on average). These findings further reveal important heterogeneity by gender as well as occupation. The negative effects seem to be driven in particular by males $(-5 \%)$, whereas there is little evidence for overall negative effects for females. ATT effects for those indecisive just before high school graduation are estimated to be between $-18 \%$ and $-29 \%$ in the total sample and $-29 \%$ for males. Looking at different occupational areas, the largest negative effects are found for STEM occupations, which are entirely attributable to men $(-7 \%$ to $-11 \%)$. Much smaller and less consistent negative effects $(-3 \%$ to $-4 \%)$ are estimated for the biggest occupational area, "business"- -but mostly for females. Since the gender differences persist for occupational subgroups, the effect heterogeneity implies that very specific types of school leavers were affected by the Bologna Process. In particular, those most likely to take technical apprenticeships (mainly men) experienced the strongest change. They seem to evaluate their probability of success at university substantially higher than before and therefore have increased their tendency towards academic study. This is supported by descriptive evidence on gender gaps in STEM subjects and in self-assessments showing that in contrast to females, less able males study STEM majors (Cimpian et al., 2020) and males assess their probability of success significantly more highly than females (Lörz et al. 2011). For these university-eligible graduates, the Bologna reform may have increased their matching to universities.

Furthermore, differentiating the number of first-year BA students by areas of study reveals not only an increase in educational attainment (upgrading) but also some impacts on major choice. For instance, the decrease in new highly educated male apprentices in STEM occupations is caused by an increase in first-year BA students in STEM, economics and "health, social work, education" majors. These switches in occupational pathways to different, albeit mostly related fields, could have severe consequences for returns to a university education, as different fields of study offer different payoffs Altonji et al. 2012 Kirkeboen et al. 2016). In addition, our findings may have substantial economic effects. While a reduced supply of highly educated apprentices could aggravate the skills shortage in Germany, expected individual returns to education could increase, as university graduates earn on average up to 420,000 euros more than VET graduates over the life cycle (Pfeiffer and Stichnoth, 2015, 2018). Moreover, the estimated total 
reduction in apprentice supply by high school graduates from the academic track (who are overcompensated by higher expected individual returns) could result in an upper bound of a net fiscal gain between 1.66 to 3.59 billion euros in total.

Our study has some limitations due to data restrictions. First, we do not have comprehensive individual-level data on post-secondary education choices across the whole implementation of the Bologna Process. Therefore, it would be insightful to review our results with other data sources (when available) that report actual post-secondary education choices. Second, due to the inconsistencies in reporting behavior in the SIAB, we have only estimated effects until 2011. It would be very beneficial to look into more recent data and investigate whether the trends we observed in this paper have proceeded. Further research could focus on the labor market effects of the Bologna Process to better understand the implications for returns to education.

Nevertheless, our study points to important policy implications. Countries that aim to reform their post-secondary education systems should be aware of the trade-offs that exist within the system. The impact of such reforms, thus, is not ex ante clear, as a strong dual apprenticeship system also comes with some considerable benefits. For instance, countries with poor labor market conditions (such as southern European countries) may face issues in integrating the increasing number of academic graduates into the labor market in comparison to a system with a stronger emphasis on VET. Analogously, countries that aim to strengthen their dual apprenticeship system modeled after Germany (e.g., Eastern European countries) should take into account the acceleration effect of the Bologna Process at the expense of highly qualified apprenticeships. 


\section{References}

Abraham, K. G. and Clark, M. A. (2006). Financial aid and students' college decisions. Journal of Human Resources, 41(3):578-610.

Acemoglu, D. and Pischke, J.-S. (1998). Why do firms train? Theory and evidence. The Quarterly Journal of Economics, 113(1):79-119.

Acemoglu, D. and Pischke, J.-S. (1999). The structure of wages and investment in general training. Journal of Political Economy, 107(3):539-572.

Alesi, B., Bürger, S., Kehm, B. M., and Teichler, U. (2005). Stand der Einführung von Bachelorund Master-Studiengängen im Bologna-Prozess sowie in ausgewählten Ländern Europas im Vergleich zu Deutschland. Endbericht. Vorgelegt am 28. Februar 2005. Technical report.

Altonji, J. G., Blom, E., and Meghir, C. (2012). Heterogeneity in human capital investments: High school curriculum, college major, and careers. Annual Review of Economics, 4(1):185-223.

Antoni, M., Ganzer, A., and Vom Berge, P. (2016). Sample of integrated labour market biographies (SIAB) 1975-2014. FDZ-Datenreport 4, Institute for Employment Research, Nürnberg.

Arcidiacono, P., Hotz, V. J., and Kang, S. (2012). Modeling college major choices using elicited measures of expectations and counterfactuals. Journal of Econometrics, 166(1):3-16.

Authoring Group Educational Reporting (AGER) (2018). Bildung in Deutschland 2018: Ein indikatorengestützter Bericht mit einer Analyse zu Wirkungen und Erträgen von Bildung. Technical report, Bielefeld.

Autor, D. H. and Dorn, D. (2013). The growth of low-skill service jobs and the polarization of the US labor market. American Economic Review, 103(5):1553-1597.

Autor, D. H., Dorn, D., and Hanson, G. H. (2013). The China syndrome: Local labor market effects of import competition in the United States. American Economic Review, 103(6):21212168 .

Baker, M., Gruber, J., and Milligan, K. (2008). Universal child care, maternal labor supply, and family well-being. Journal of Political Economy, 116(4):709-745.

Bauernschuster, S., Hener, T., and Rainer, H. (2016). Children of a (policy) revolution: The introduction of universal child care and its effect on fertility. Journal of the European Economic Association, 14(4):975-1005.

Becker, R. and Hecken, A. E. (2009). Higher education or vocational training? Acta Sociologica, $52(1): 25-45$.

Bellmann, L., Gerner, H.-D., and Leber, U. (2014). Firm-provided training during the Great Recession. Jahrbücher für Nationalökonomie und Statistik, 234(1):5-22.

Bellmann, L. and Hübler, O. (2014). The skill shortage in German establishments before, during and after the Great Recession. Jahrbücher für Nationalökonomie und Statistik, 234(6):800-828.

Berlinski, S., Galiani, S., and Gertler, P. (2009). The effect of pre-primary education on primary school performance. Journal of Public Economics, 93(1):219-234.

Björklund, A. and Salvanes, K. G. (2011). Education and family background: Mechanisms and policies. In Hanushek, E. A., Machin, S., and Woessmann, L., editors, Handbook of the Economics of Education, volume 3, pages 201-247. Elsevier.

Blatter, M., Muehlemann, S., Schenker, S., and Wolter, S. C. (2016). Hiring costs for skilled workers and the supply of firm-provided training. Oxford Economic Papers, 68(1):238-257. 
Bobonis, G. J. and Finan, F. (2009). Neighborhood peer effects in secondary school enrollment decisions. Review of Economics and Statistics, 91(4):695-716.

Bologna Declaration (1999). Joint declaration of the European ministers of education.

Bondonio, D. and Berton, F. (2018). The impact of degree duration on higher education participation: Evidence from a large-scale natural experiment. Oxford Bulletin of Economics and Statistics, 80(5):905-930.

Breen, R. and Goldthorpe, J. H. (1997). Explaining educational differentials: Towards a formal rational action theory. Rationality and Society, 9(3):275-305.

Briedis, K., Heine, C., Konegen-Grenier, C., and Schröder, A.-K. (2011). Mit dem Bachelor in den Beruf. Technical report, Stifterverband für die Deutsche Wissenschaft, Essen.

Bruckmeier, K. and Wigger, B. U. (2014). The effects of tuition fees on transition from high school to university in Germany. Economics of Education Review, 41:14-23.

Brunello, G. (2009). The effect of economic downturns on apprenticeships and initial workplace training: A review of the evidence. Empirical Research in Vocational Education and Training, $1(2): 145-171$.

Brunello, G. and Rocco, L. (2017). The labor market effects of academic and vocational education over the life cycle: Evidence based on a British cohort. Journal of Human Capital, 11(1):106166.

Cantoni, D., Chen, Y., Yang, D. Y., Yuchtman, N., and Zhang, Y. J. (2017). Curriculum and ideology. Journal of Political Economy, 125(2):338-392.

Cappellari, L. and Lucifora, C. (2009). The "Bologna Process" and college enrollment decisions. Labour Economics, 16(6):638-647.

Cardoso, A. R., Portela, M., Sa, C., and Alexandre, F. (2008). Demand for higher education programs: The impact of the Bologna Process. CESifo Economic Studies, 54(2):229-247.

CEDEFOP (2018). Skills forecast: Trends and challenges to 2030. Cedefop reference series 108, Luxembourg.

Cimpian, J. R., Kim, T. H., and McDermott, Z. T. (2020). Understanding persistent gender gaps in STEM. Science (New York, N.Y.), 368(6497):1317-1319.

Cornwell, C., Mustard, D. B., and Sridhar, D. J. (2006). The enrollment effects of meritbased financial aid: Evidence from Georgia's HOPE program. Journal of Labor Economics, $24(4): 761-786$.

Correia, S., Guimarães, P., and Zylkin, T. (2019a). ppmlhdfe: Fast Poisson estimation with highdimensional fixed effects. Unpublished Manuscript. https://arxiv.org/abs/1903.01690.

Correia, S., Guimarães, P., and Zylkin, T. (2019b). Verifying the existence of maximum likelihood estimates for generalized linear models. Unpublished manuscript. https://arxiv.org/abs/ 1903.01633

Denning, J. T. (2017). College on the cheap: Consequences of community college tuition reductions. American Economic Journal: Economic Policy, 9(2):155-188.

Di Pietro, G. (2012). The Bologna Process and widening participation in university education: New evidence from Italy. Empirica, 39(3):357-374.

Dwenger, N., Storck, J., and Wrohlich, K. (2012). Do tuition fees affect the mobility of university applicants? Evidence from a natural experiment. Economics of Education Review, 31(1):155167. 
Dynarski, S. M. (2003). Does aid matter? Measuring the effect of student aid on college attendance and completion. American Economic Review, 93(1):279-288.

Fabian, G., Hillmann, J., Trennt, F., and Briedis, K. (2016). Hochschulabschlüsse nach Bologna: Werdegänge der Bachelor- und Masterabsolvent(inn)en des Prüfungsjahrgangs 2013. Forum Hochschule 1/2016, German Centre for Higher Education Research and Science Studies, Hannover.

Federal Institute for Vocational Education and Training (BIBB) (2009). Datenreport zum Berufsbildungsbericht 2009: Informationen und Analysen zur Entwicklung der beruflichen Bildung. Technical report, BIBB, Bonn.

Federal Institute for Vocational Education and Training (BIBB) (2019). Datenreport zum Berufsbildungsbericht 2019: Informationen und Analysen zur Entwicklung der beruflichen Bildung. Technical report, BIBB, Bonn.

Federal Statistical Office (Destatis) (2018a). Bildungsstand der Bevölkerung: Ergebnisse des Mikrozensus 2017.

Federal Statistical Office (Destatis) (2018b). Nichtmonetäre hochschulstatistische Kennzahlen. Fachserie 11, Reihe 4.3.1 - 1980-2017.

Federal Statistical Office (Destatis) (2019). Berufliche Bildung: Fachserie 11, Reihe 3. 2018.

Fitzenberger, B., Osikominu, A., and Voelter, R. (2006). Imputation rules to improve the education variable in the IAB employment subsample. Schmollers Jahrbuch, 126(3):405-436.

Golsteyn, B. H. H. and Stenberg, A. (2017). Earnings over the life course: General versus vocational education. Journal of Human Capital, 11(2):167-212.

Hahm, S. and Kluve, J. (2019). Better with Bologna? Tertiary education reform and student outcomes. Education Economics, 27(4):425-449.

Hanushek, E. A., Schwerdt, G., Woessmann, L., and Zhang, L. (2017). General education, vocational education, and labor-market outcomes over the lifecycle. Journal of Human Resources, 52(1):48-87.

Hanushek, E. A. and Woessmann, L. (2015). The knowledge capital of nations: Education and the economics of growth. MIT Press.

Haussen, T. and Uebelmesser, S. (2018). Job changes and interregional migration of graduates. Regional Studies, 52(10):1346-1359.

Havnes, T. and Mogstad, M. (2011). No child left behind: Subsidized child care and children's long-run outcomes. American Economic Journal: Economic Policy, 3(2):97-129.

Helbig, M., Baier, T., and Kroth, A. (2012). Die Auswirkung von Studiengebühren auf die Studierneigung in Deutschland. Evidenz aus einem natürlichen Experiment auf Basis der HISStudienberechtigtenbefragung. Zeitschrift für Soziologie, 41(3):227-246.

Heller, D. E. (1997). Student price response in higher education. The Journal of Higher Education, 68(6):624-659.

Heublein, U. and Schmelzer, R. (2018). Die Entwicklung der Studienabbruchquoten an den deutschen Hochschulen: Berechnungen auf Basis des Absolventenjahrgangs 2016. DZHWProjektbericht, German Centre for Higher Education Research and Science Studies, Hannover.

Hochschulrektorenkonferenz (HRK) (2004). Bologna-Reader: Texte und Hilfestellungen zur Umsetzung der Ziele des Bologna-Prozesses an deutschen Hochschulen. Beiträge zur Hochschulpolitik 8/2004, HRK Service-Stelle Bologna. 
Hochschulrektorenkonferenz (HRK) (2019). Statistische Daten zu Studienangeboten an Hochschulen in Deutschland: Studiengänge, Studierende, Absolventinnen und Absolventen: Wintersemester 2019/2020. Statistiken zur Hochschulpolitik 2/2019, Berlin.

Horstschräer, J. and Sprietsma, M. (2015). The effects of the introduction of bachelor degrees on college enrollment and dropout rates. Education Economics, 23(3):296-317.

Hübner, M. (2012). Do tuition fees affect enrollment behavior? Evidence from a 'natural experiment' in Germany. Economics of Education Review, 31(6):949-960.

Hutter, C., Möller, J., and Penninger, M. (2015). Reducing the need for heuristic rules An iterative algorithm for imputing the education variable in SIAB. Schmollers Jahrbuch, 135(3):355-388.

Jost, O., Seibert, H., and Wiethölter, D. (2019). Auszubildende in MINT-Berufen pendeln besonders häufig: Regionale Mobilität von Lehrlingen. IAB-Kurzbericht 2/2019, Institute for Employment Research, Nürnberg.

Kirkeboen, L. J., Leuven, E., and Mogstad, M. (2016). Field of study, earnings, and self-selection. The Quarterly Journal of Economics, 131(3):1057-1111.

Kleinert, C. and Kruppe, T. (2012). Neue Typisierung: Regionale Ausbildungsmärkte verändern sich. IAB-Kurzbericht 17/2012, Institute for Employment Research, Nürnberg.

Kosfeld, R. and Werner, A. (2012). Deutsche Arbeitsmarktregionen - Neuabgrenzung nach den Kreisgebietsreformen 2007-2011. Raumforschung und Raumordnung, 70(1):49-64.

Lörz, M., Quast, H., and Woisch, A. (2011). Bildungsintentionen und Entscheidungsprozesse: Studienberechtigte 2010 ein halbes Jahr vor Schulabgang. Forum Hochschule 14/2011, HIS, Hannover.

Lüthi, S. and Wolter, S. C. (2020). Are apprenticeships business cycle proof? Swiss Journal of Economics and Statistics, 156(1).

Maier, T., Mönnig, A., and Zika, G. (2015). Labour demand by industrial sector, occupational field and qualification until 2025-Model calculations using the IAB/INFORGE model. Economic Systems Research, 27(1):19-42.

Margaryan, S., Saniter, N., Schumann, M., and Siedler, T. (2020). Do internships pay off? Journal of Human Resources, 0418-9460R2.

McGuigan, M., McNally, S., and Wyness, G. (2016). Student awareness of costs and benefits of educational decisions: Effects of an information campaign. Journal of Human Capital, 10(4):482-519.

Méndez, F. and Sepúlveda, F. (2012). The cyclicality of skill acquisition: Evidence from panel data. American Economic Journal: Macroeconomics, 4(3):128-152.

Meyer, T. and Thomsen, S. L. (2016). How important is secondary school duration for postsecondary education decisions? Evidence from a natural experiment. Journal of Human Capital, 10(1):67-108.

Meyer, T., Thomsen, S. L., and Schneider, H. (2019). New evidence on the effects of the shortened school duration in the German states: An evaluation of post-secondary education decisions. German Economic Review, 20(4):8.

Mohrenweiser, J. and Backes-Gellner, U. (2010). Apprenticeship training: For investment or substitution? International Journal of Manpower, 31(5):545-562.

Mohrenweiser, J. and Zwick, T. (2009). Why do firms train apprentices? The net cost puzzle reconsidered. Labour Economics, 16(6):631-637. 
Mohrenweiser, J., Zwick, T., and Backes-Gellner, U. (2019). Poaching and firm-sponsored training. British Journal of Industrial Relations, 57(1):143-181.

Morin, L.-P. (2015). Do men and women respond differently to competition? Evidence from a major education reform. Journal of Labor Economics, 33(2):443-491.

Muehlemann, S., Pfann, G. A., Pfeifer, H., and Dietrich, H. (2018). The effects of supply shocks in the market for apprenticeships: Evidence from a German high school reform. IZA Discussion Papers 11264, Institute of Labor Economics, Bonn.

Neill, C. (2009). Tuition fees and the demand for university places. Economics of Education Review, 28(5):561-570.

Neugebauer, M. (2015). The introduction of bachelor degrees and the under-representation of students from low social origin in higher education in Germany: A pseudo-panel approach. European Sociological Review, 31(5):591-602.

Neugebauer, M. and Weiss, F. (2018). A transition without tradition: Earnings and unemployment risks of academic versus vocational education after the Bologna Process. Zeitschrift für Soziologie, 47(5):349-363.

OECD (2014). Education at a glance 2014: OECD indicators. Technical report, OECD Publishing, Paris. http://dx.doi.org/10.1787/eag-2014-en

Oreopoulos, P. and Dunn, R. (2013). Information and college access: Evidence from a randomized field experiment. The Scandinavian Journal of Economics, 115(1):3-26.

Ors, E., Palomino, F., and Peyrache, E. (2013). Performance gender gap: Does competition matter? Journal of Labor Economics, 31(3):443-499.

Peter, F. H. and Zambre, V. (2017). Intended college enrollment and educational inequality: Do students lack information? Economics of Education Review, 60:125-141.

Pfeiffer, F. and Stichnoth, H. (2015). Fiskalische und individuelle Bildungsrenditen - Aktuelle Befunde für Deutschland. Perspektiven der Wirtschaftspolitik, 16(4):393-411.

Pfeiffer, F. and Stichnoth, H. (2018). Fiskalische und individuelle Nettoerträge und Renditen von Bildungsinvestitionen im jungen Erwachsenenalter. ZEW Discussion Paper No. 18-043, ZEW, Mannheim.

Price, B. M., Janssen, S., and Nagler, M. (2017). Cohort-crowding in entry-level labor markets: Evidence from German high school reforms. Unpublished manuscript.

PricewaterhouseCoopers (PwC) (2018). European Private Business Survey. Versteckte Reserve: Das ungenutzte Potenzial des Mittelstands. Technical report, PwC. https://www.pwc.de/ de/mittelstand/european-private-business-survey-2018-de-final.pdf

Rehn, T., Brandt, G., Fabian, G., and Briedis, K. (2011). Hochschulabschlüsse im Umbruch: Studium und Übergang von Absolventinnen und Absolventen reformierter und traditioneller Studiengänge des Jahrgangs 2009. Forum Hochschule 17/2011, HIS, Hannover.

Riphahn, R. T. and Zibrowius, M. (2016). Apprenticeship, vocational training, and early labor market outcomes - Evidence from East and West Germany. Education Economics, 24(1):33-57.

Ruhose, J., Thomsen, S. L., and Weilage, I. (2020). Are older workers willing to learn? IZA Discussion Papers No. 13416, Institute of Labor Economics, Bonn.

Ryan, P. (2001). The school-to-work transition: A cross-national perspective. Journal of Economic Literature, 39(1):34-92. 
Sandner, M. and Thomsen, S. L. (2020). Preventing child maltreatment: Beneficial side effects of public childcare provision. Hannover Economic Papers No. 669, Leibniz Universität Hannover, Wirtschaftswissenschaftliche Fakultät.

Schmidheiny, K. and Siegloch, S. (2020). On event studies and distributed-lags in two-way fixed effects models: Identification, equivalence, and generalization. ZEW Discussion Papers 20-017, ZEW - Centre for European Economic Research, Mannheim.

Schneider, H. and Franke, B. (2014). Bildungsentscheidungen von Studienberechtigten: Studienberechtigte 2012 ein halbes Jahr vor und ein halbes Jahr nach Schulabschluss. Forum Hochschule 6/2014, German Centre for Higher Education Research and Science Studies, Hannover.

Schneider, H., Franke, B., Woisch, A., and Spangenberg, H. (2017). Erwerb der Hochschulreife und nachschulische Übergänge von Studienberechtigten: Studienberechtigte 2015 ein halbes Jahr vor und ein halbes Jahr nach Schulabschluss. Forum Hochschule 4/2017, German Centre for Higher Education Research and Science Studies, Hannover.

Schomburg, H. (2011). Bachelor graduates in Germany: Internationally mobile, smooth transition and professional success. In Schomburg, H. and Teichler, U., editors, Employability and mobility of bachelor graduates in Europe, pages 89-110. SensePublishers, Rotterdam.

Seyda, S. and Bußmann, S. (2014). Fachkräfteengpässe in Unternehmen: In vielen Berufsgattungen bestehen seit Längerem Engpässe. KOFA-Studie No. 1/2014, Institut der deutschen Wirtschaft (IW) and Kompetenzzentrum Fachkräftesicherung (KOFA), Köln.

Spiess, C. K. and Wrohlich, K. (2010). Does distance determine who attends a university in Germany? Economics of Education Review, 29(3):470-479.

Steiner, V. and Wrohlich, K. (2012). Financial student aid and enrollment in higher education: New evidence from Germany. The Scandinavian Journal of Economics, 114(1):124-147.

Teichler, U. (2011). Bologna - Motor or stumbling block for the mobility and employability of graduates? In Schomburg, H. and Teichler, U., editors, Employability and mobility of bachelor graduates in Europe, pages 3-41. SensePublishers, Rotterdam.

Thomsen, S. L. and von Haaren-Giebel, F. (2016). Did tuition fees in Germany constrain students' budgets? New evidence from a natural experiment. IZA Journal of European Labor Studies, 5(1):6.

Wenzelmann, F., Jansen, A., Pfeifer, H., and Schönfeld, G. (2015). Apprenticeship training in Germany remains investment-focused: Results of BIBB cost-benefit survey 2012/13. BIBB Report 1, Federal Institute for Vocational Education and Training. https://www.bibb.de/ en/25852.php

Wiswall, M. and Zafar, B. (2015). Determinants of college major choice: Identification using an information experiment. The Review of Economic Studies, 82(2):791-824.

Witte, J., van der Wende, M., and Huisman, J. (2008). Blurring boundaries: How the Bologna Process changes the relationship between university and non-university higher education in Germany, the Netherlands and France. Studies in Higher Education, 33(3):217-231.

Wolter, S. C. and Ryan, P. (2011). Apprenticeship. In Hanushek, E. A., Welch, F., Machin, S., and Woessmann, L., editors, Handbook of the economics of education, volume 3 of Handbook of the Economics of Education, pages 521-576. Elsevier.

Wooldridge, J. M. (1999). Distribution-free estimation of some nonlinear panel data models. Journal of Econometrics, 90(1):77-97.

Zimmermann, K. F., Biavaschi, C., Eichhorst, W., Giulietti, C., Kendzia, M. J., Muravyev, A., Pieters, J., Rodríguez-Planas, N., and Schmidl, R. (2013). Youth unemployment and vocational training. Foundations and Trends® in Microeconomics, 9(1-2):1-157. 


\section{Figures and Tables}

Figure 1: The education system in Germany

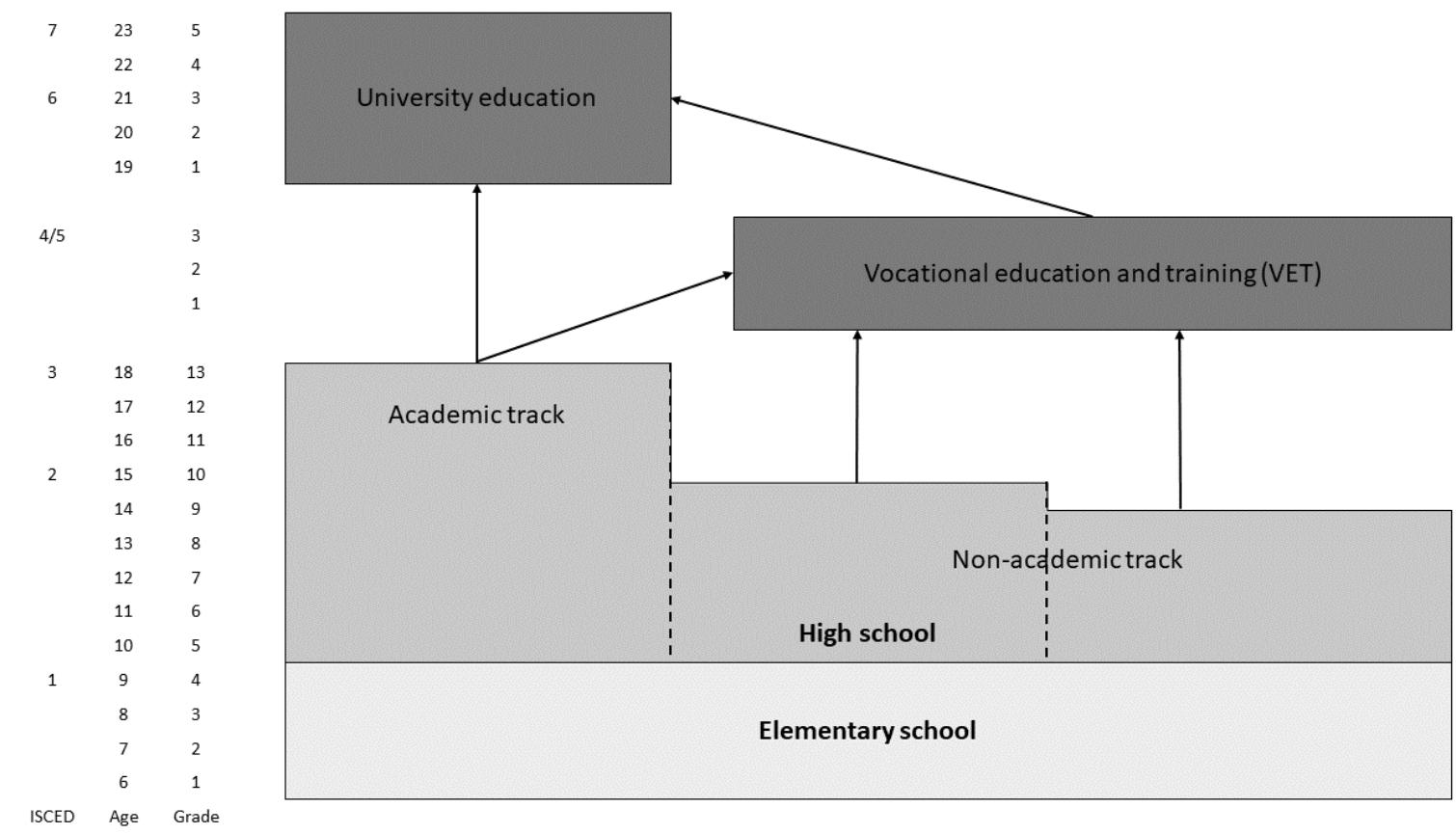

Notes: The figure shows stylized tracks and educational pathways in the German education system. 


\section{Figure 2: Comparison of new apprentices identified in different data sources}

Panel A. Number of new apprentices

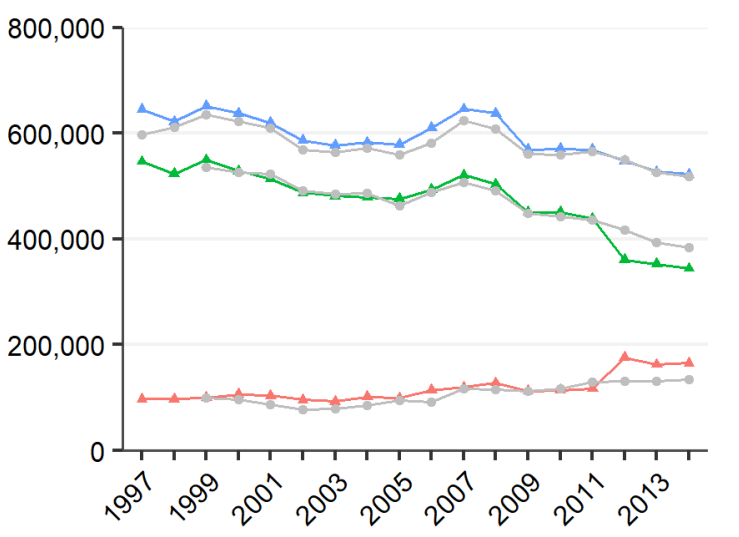

Panel B. As share of total new apprentices

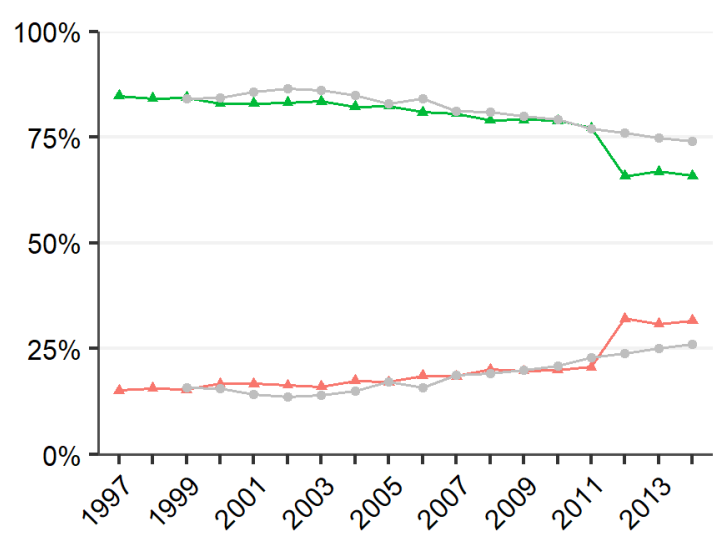

- Destatis \& SIAB

Notes: The figure shows the sum of new apprentices across time and by type of qualification. Panel A records new apprentices in absolute terms, Panel B the share of the two different qualification levels. Highly educated refer to those from the academic school track, less-educated to those from the non-academic school track. Missing values are imputed via imputation procedure IP1 proposed by Fitzenberger et al. (2006). Apprentices with still missing information on school qualification are not shown. The numbers identified in the SIAB ( $2 \%$ random sample) are scaled by factor 50 to account for the total population, shown in colors and marked by triangles. The numbers obtained from Destatis (2019) are depicted in grey and marked by circles. Calculations by the authors.

Figure 3: New highly educated apprentices by occupational areas and gender

Panel A. New male highly educated apprentices

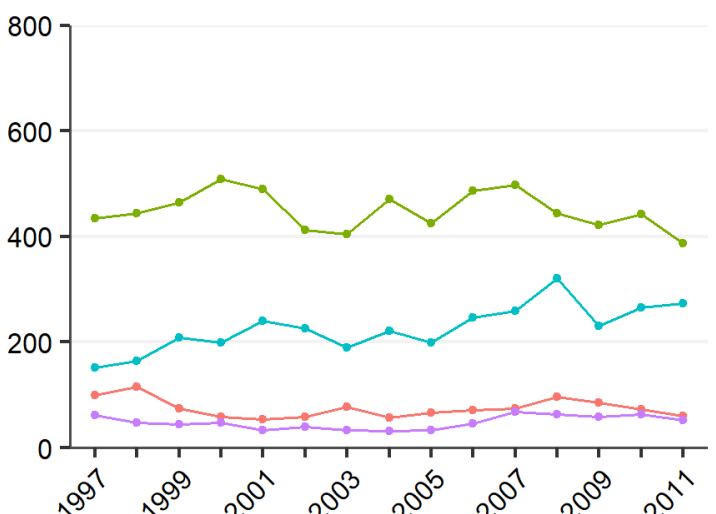

Panel B. New female highly educated apprentices

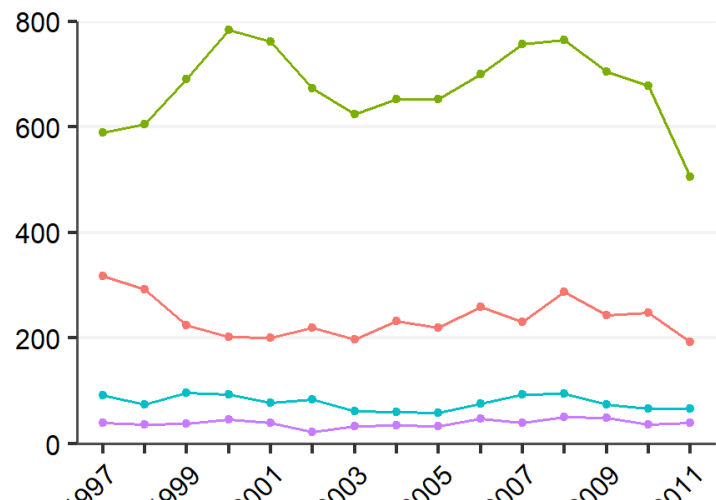

$\rightarrow$ Health/social work/education $\rightarrow$ Business $\rightarrow$ STEM $\rightarrow$ Other

Notes: The figure shows the sum of new highly educated apprentices across time and by four occupational areas. Panel A shows males, Panel B females. Numbers are obtained from the SIAB and, thus, represent a $2 \%$ random sample of all employees subject to social security contributions in Germany. Calculations by the authors. 
Figure 4: Expansion patterns of first-year BA students across regions, areas of study and years

Panel A. Share of first-year BA students per total first-year students by areas of study and regions
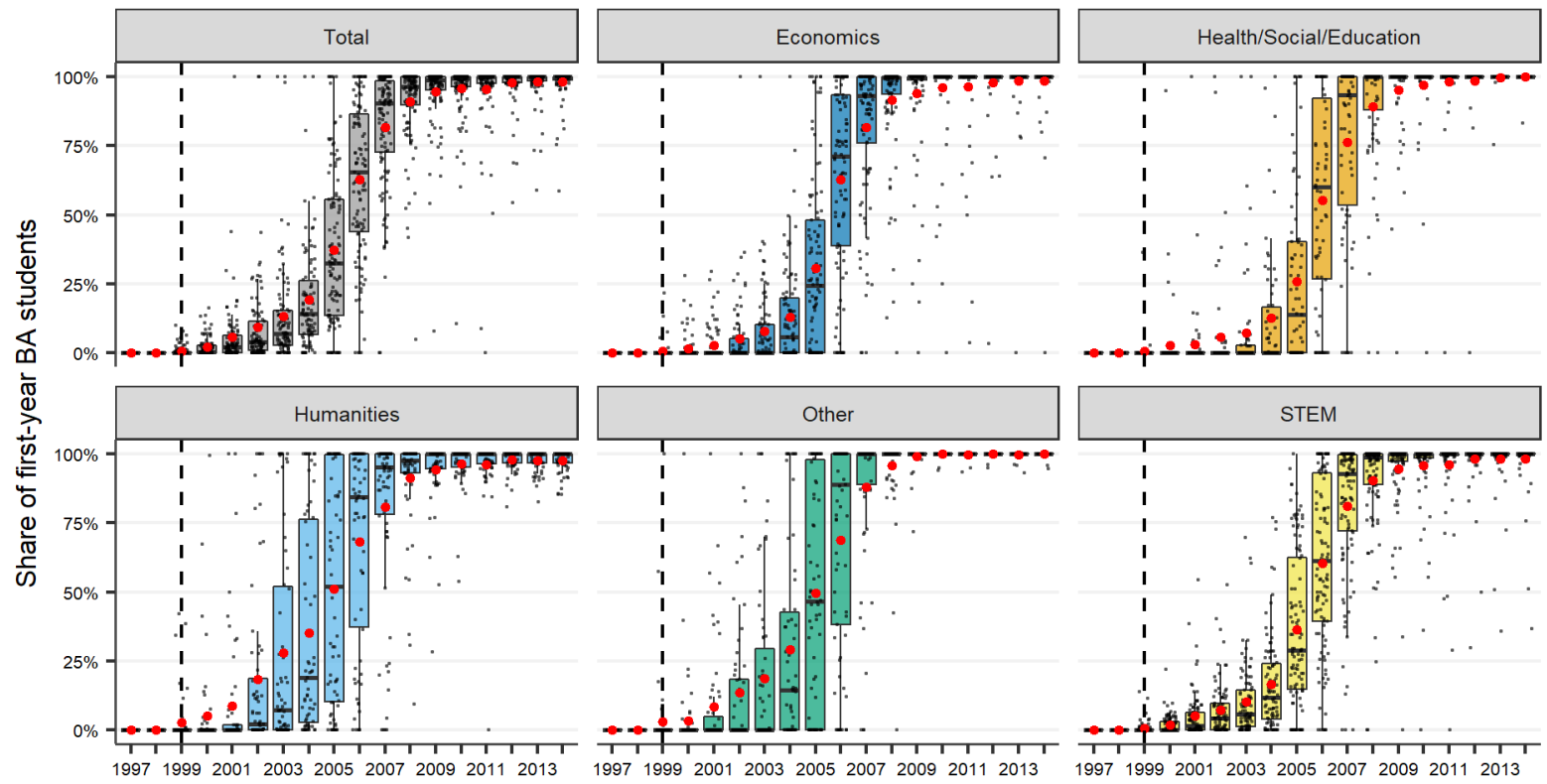

Panel B. Number of first-year BA students by areas of study and regions
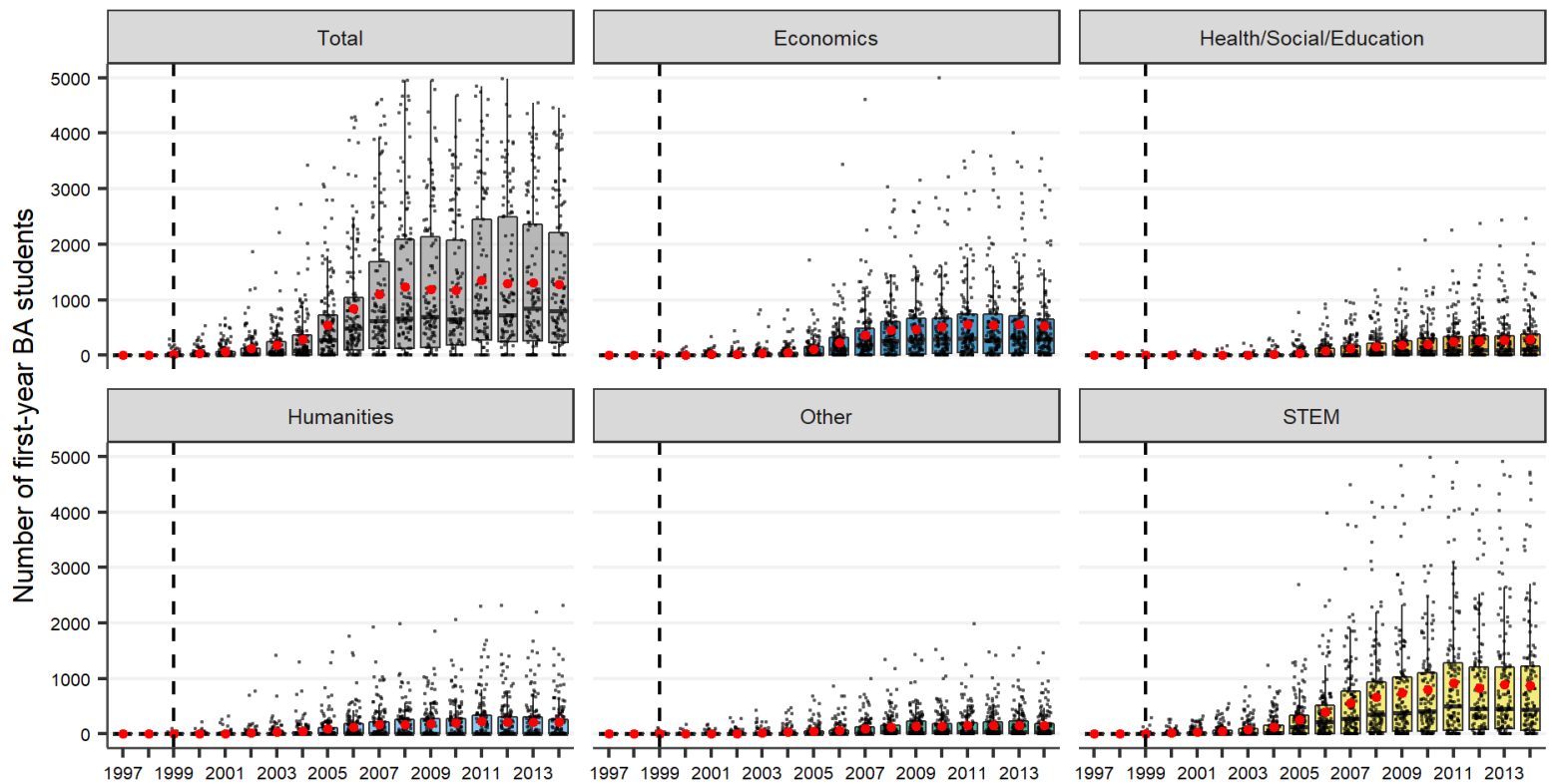

Notes: The figure shows box plots for different Bologna implementation indicators across German labor market regions, areas of study and years. The first panel refers to the share of first-year BA students per total first-year students studying for BA or former degrees, the second panel refers to the absolute number of first-year BA students. The black horizontal lines depict the median, the red dots the mean, colored boxes the interquartile range, the black vertical lines the 1.5 interquartile range and the black dots individual observations (i.e., labor market regions). Labor market regions with less than 50 total first-year students in the specific year are dropped in the first panel. For reasons of presentation, outliers beyond 5,000 first-year students are excluded in Panel B (see for maximum value Table A-4 in the appendix). Calculations by the authors. 
Figure 5: Composition of total first-year BA students by areas of study

Panel A. Absolute number of first-year BA students

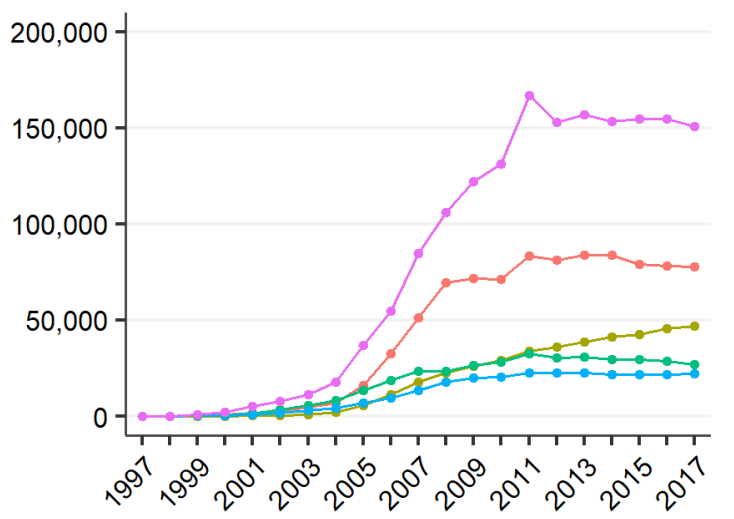

Panel B. Share of first-year BA students

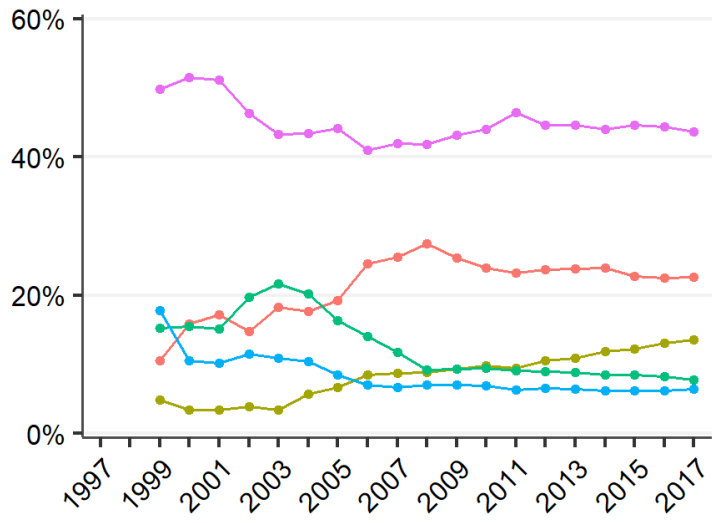

$\rightarrow$ Economics $\rightarrow$ Health/Social work/education $\rightarrow$ Humanities $\rightarrow$ Other $\rightarrow$ STEM

Notes: The figure shows the sum of all first-year BA students by six different areas of study. Panel A reports absolute numbers, Panel B respective shares. Calculations by the authors.

Figure 6: Generalized event study with three leads and one lag of first-year BA students

Panel A. Baseline with fixed effects and controls

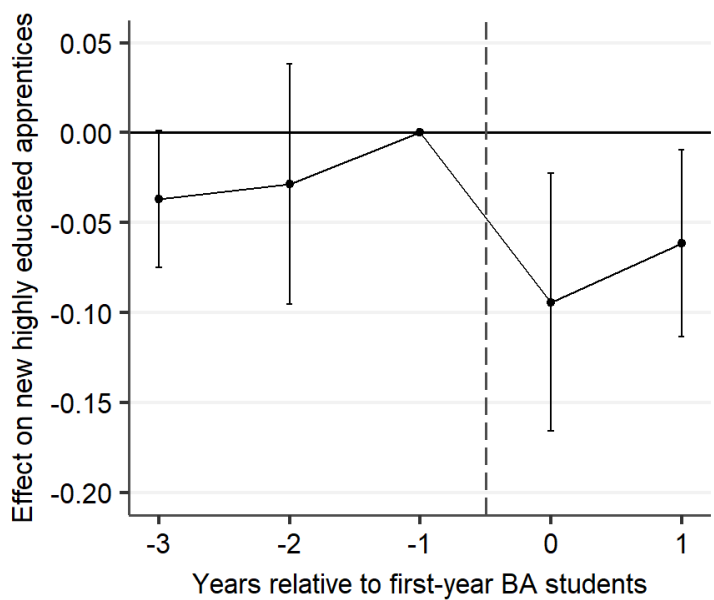

Panel B. Incl. region-specific linear time trends

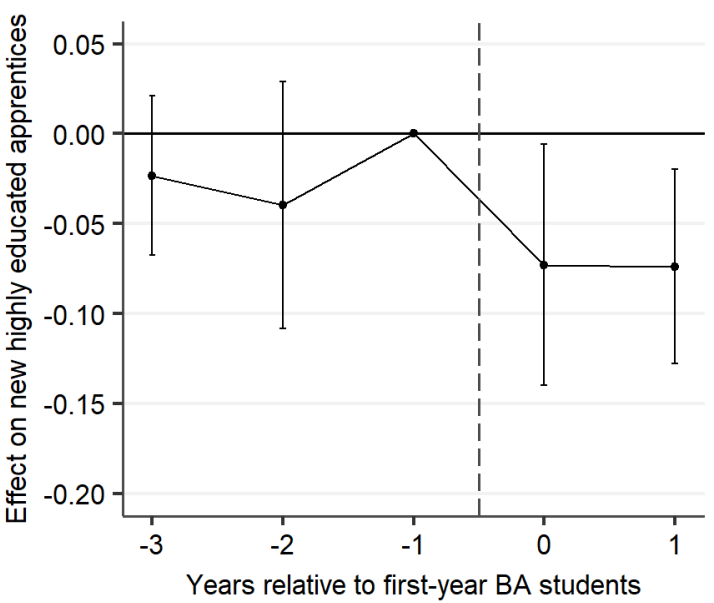

Notes: The figure plots the results from a generalized event study analysis. It allows for multiple events with varying treatment size with an effect window of three leads and one lag (specified as in equation (13) and (14) in Schmidheiny and Siegloch (2020)), where the effect at year -1 is normalized to zero. Panel A refers to a setting including region and year fixed effects as well as the regional controls explained in Section 4.2, Panel B additionally includes region-specific linear time trends. The graphs show the dynamic effect of the average regional increase in first-year BA students across the observation period from 1999-2011. Coefficients can be interpreted as semi-elasticities. 95\% confidence intervals are plotted. Calculations by the authors. 
Figure 7: Occupation-specific effects by areas of study
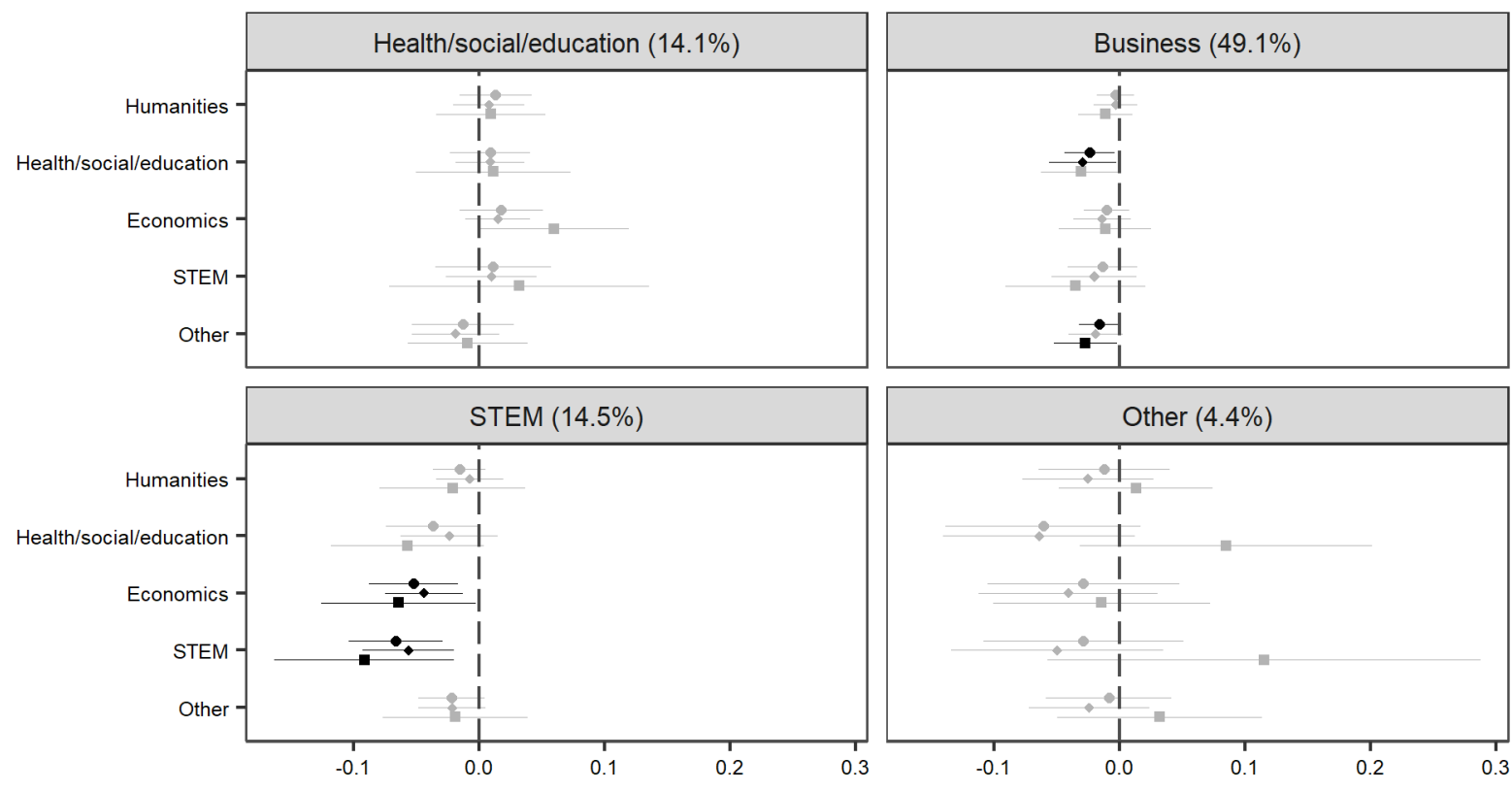

- Baseline - Reg controls - Reg $x$ trend

$p>0.05 \bullet p<0.05$

Notes: The figure shows estimated coefficients and $95 \%$ confidence intervals from estimating equation (2) separately for all $4 \times 5$ combinations of occupational areas and major areas. Coefficients represent the $\theta \times 100 \%$ change in new highly educated apprentices in the respective occupational area (panels) due to the average regional increase in first-year BA students in the respective area of study (y-axis) across the observation period from 1999-2011. o indicates coefficients from a baseline model, including only region and year fixed effects. $\diamond$ adds the control variables explained in Section 4.2, $\square$ additionally includes a region-specific linear time trend. Brackets indicate the share of each occupational area in 2010. The remaining share consists of unassigned or missing occupations. Detailed regression results are provided in Tables A-7, A-8 and A-9 in the appendix. Calculations by the authors. 


\title{
Figure 8: Occupation-specific effects by areas of study and gender
}

\author{
(a) Males
}

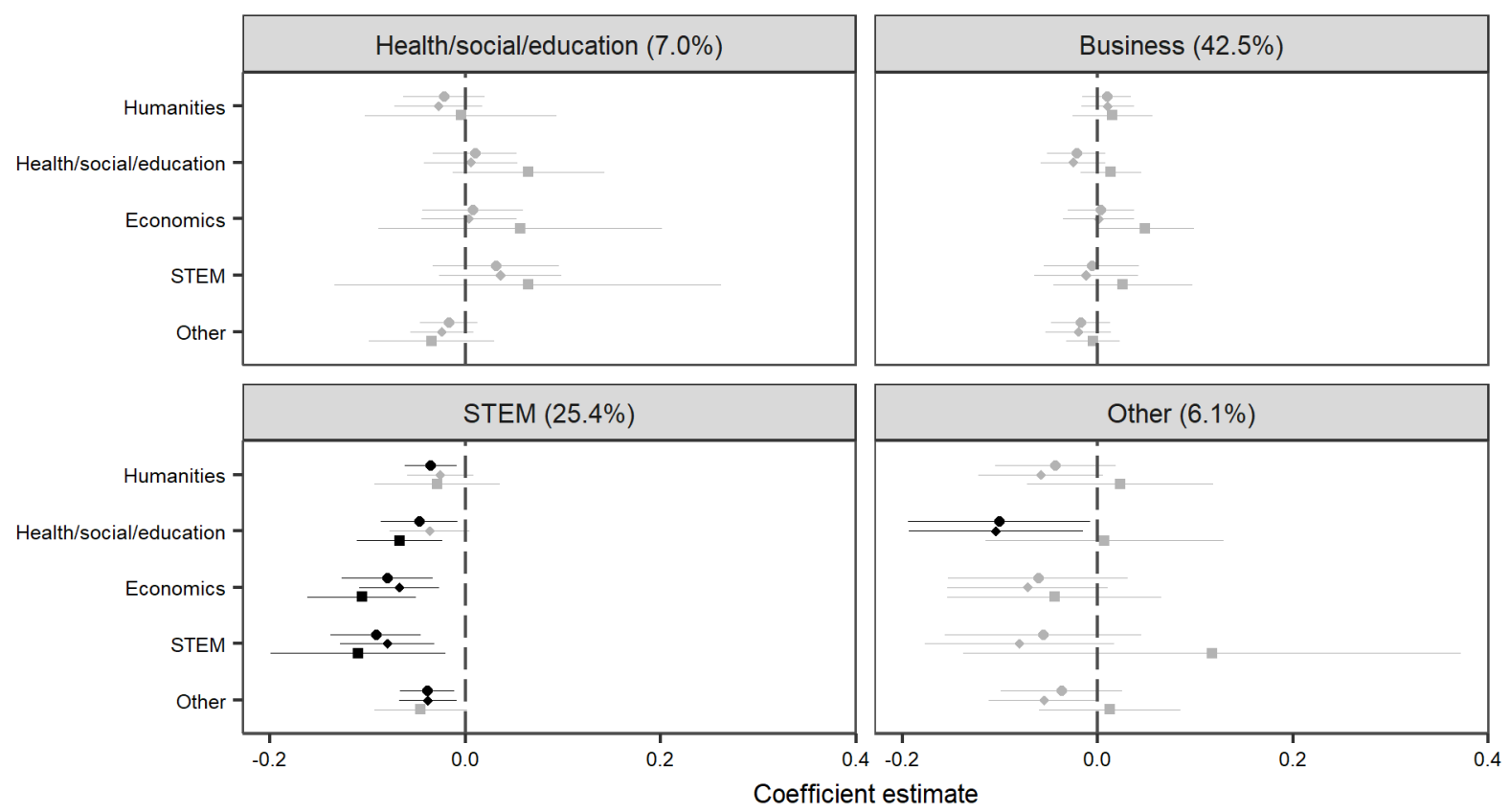

- Baseline - Reg controls - Reg x trend $\quad p>0.05 \bullet p<0.05$

(b) Females
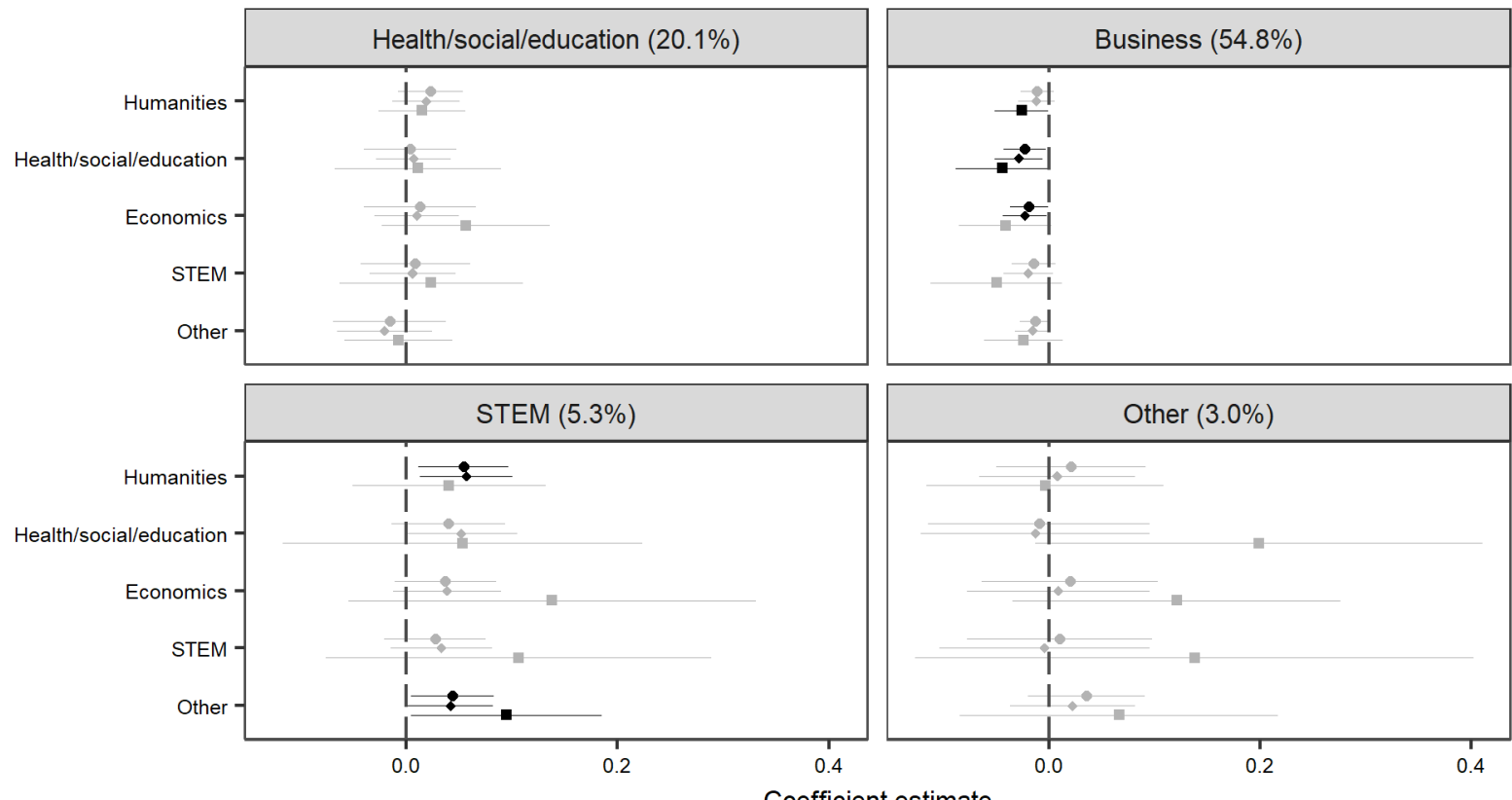

- Baseline - Reg controls - Reg $x$ trend

$p>0.05 \cdot p<0.05$

Notes: The figure shows estimated coefficients and 95\% confidence intervals from estimating equation (2) separately for all $4 \times 5$ combinations of occupational areas and major areas. Coefficients represent the $\theta \times 100 \%$ change in new highly educated apprentices in the respective occupational area (panels) due to the average regional increase in first-year BA students in the respective area of study (y-axis) across the observation period from 1999-2011. ○ indicates coefficients from a baseline model, including only region and year fixed effects. $\diamond$ adds the control variables explained in Section 4.2 $\square$ additionally includes a region-specific linear time trend. Panel A refers to regressions for males, Panel B for females. Brackets indicate the share of each occupational area in 2010. The remaining share consists of unassigned or missing occupations. Detailed regression results are provided in Tables A-7 A-8 and A-9 in the appendix. Calculations by the authors. 
Table 1: Balancing test and BA expansion prediction

\begin{tabular}{|c|c|c|c|c|}
\hline & \multirow{3}{*}{$\begin{array}{c}\frac{\text { Balancing test }}{(1)} \\
\text { Fy BA stud }\end{array}$} & \multicolumn{3}{|c|}{ Expansion prediction } \\
\hline & & $(2)$ & (3) & (4) \\
\hline & & Early & Mid & Late \\
\hline Log trainees per 1,000 employees & $\begin{array}{l}-1.382 \\
(1.180)\end{array}$ & $\begin{array}{c}0.228 \\
(0.825)\end{array}$ & $\begin{array}{c}0.342 \\
(0.658)\end{array}$ & $\begin{array}{l}-0.094 \\
(0.649)\end{array}$ \\
\hline Log school leavers & $\begin{array}{c}-2.591^{* * *} \\
(0.715)\end{array}$ & $\begin{array}{l}0.205^{*} \\
(0.109)\end{array}$ & $\begin{array}{c}0.263^{* * *} \\
(0.087)\end{array}$ & $\begin{array}{c}0.303^{* * *} \\
(0.086)\end{array}$ \\
\hline Share school leavers w/ uni. entr. qual. & $\begin{array}{c}0.016 \\
(0.015)\end{array}$ & $\begin{array}{c}0.031 \\
(0.019)\end{array}$ & $\begin{array}{c}0.012 \\
(0.015)\end{array}$ & $\begin{array}{l}-0.002 \\
(0.015)\end{array}$ \\
\hline Unemployment rate & $\begin{array}{c}0.118 \\
(0.075)\end{array}$ & $\begin{array}{c}0.015 \\
(0.026)\end{array}$ & $\begin{array}{c}-0.051^{* *} \\
(0.021)\end{array}$ & $\begin{array}{c}-0.066^{* * *} \\
(0.021)\end{array}$ \\
\hline Share employment in industry & $\begin{array}{c}-0.170^{* * *} \\
(0.062)\end{array}$ & $\begin{array}{l}-0.001 \\
(0.011)\end{array}$ & $\begin{array}{l}-0.005 \\
(0.009)\end{array}$ & $\begin{array}{l}-0.008 \\
(0.008)\end{array}$ \\
\hline Log pop density & $\begin{array}{c}11.776^{* * *} \\
(4.475)\end{array}$ & $\begin{array}{l}-0.043 \\
(0.191)\end{array}$ & $\begin{array}{l}0.273^{*} \\
(0.152)\end{array}$ & $\begin{array}{c}0.362^{* *} \\
(0.150)\end{array}$ \\
\hline Log GDP per capita & $\begin{array}{c}-3.824^{* *} \\
(1.772)\end{array}$ & $\begin{array}{c}0.621 \\
(0.536)\end{array}$ & $\begin{array}{l}-0.114 \\
(0.428)\end{array}$ & $\begin{array}{l}-0.154 \\
(0.422)\end{array}$ \\
\hline Share employees w/ academic qual. & $\begin{array}{c}0.815^{* * *} \\
(0.302)\end{array}$ & $\begin{array}{c}-0.055^{*} \\
(0.029)\end{array}$ & $\begin{array}{c}0.034 \\
(0.023)\end{array}$ & $\begin{array}{c}0.037 \\
(0.023)\end{array}$ \\
\hline Share pop aged $18-25$ & $\begin{array}{c}0.654^{* * *} \\
(0.187)\end{array}$ & $\begin{array}{c}0.181 \\
(0.144)\end{array}$ & $\begin{array}{c}0.036 \\
(0.115)\end{array}$ & $\begin{array}{c}0.048 \\
(0.113)\end{array}$ \\
\hline Share female pop & $\begin{array}{l}-0.610 \\
(0.659)\end{array}$ & $\begin{array}{c}0.128 \\
(0.143)\end{array}$ & $\begin{array}{l}-0.106 \\
(0.114)\end{array}$ & $\begin{array}{c}-0.200^{*} \\
(0.113)\end{array}$ \\
\hline Share foreign pop & $\begin{array}{l}-0.341 \\
(0.216)\end{array}$ & $\begin{array}{c}0.034 \\
(0.034)\end{array}$ & $\begin{array}{l}-0.014 \\
(0.027)\end{array}$ & $\begin{array}{l}-0.045 \\
(0.027)\end{array}$ \\
\hline Observations & 2115 & 92 & 92 & 92 \\
\hline$R^{2}$ & 0.483 & 0.291 & 0.540 & 0.552 \\
\hline F-test & 7.854 & 2.979 & 8.523 & 8.963 \\
\hline $\mathrm{P}$-value joint F-test & 0.000 & 0.002 & 0.000 & 0.000 \\
\hline
\end{tabular}

Notes: The table reports estimates from regressing the number of first-year BA students (fy BA stud) (column 1) on a set of regional covariates while conditioning on region and year fixed effects. In addition, the table shows predictions of BA expansion by regional pre-treatment characteristics in 1999. The dependent variables are defined as: early expanders $=$ above-median number of first-year BA students in 2005 (column 2); mid expanders $=$ above-median number of first-year BA students in 2008 (column 3); strong expanders $=$ above-median number of first-year BA students in 2011 (column 4). The prediction sample is limited to the 93 regions that contain first-year students in 1999. The last row reports the p-value from an F-test of joint significance for all regional characteristics. All coefficients on shares (and unemployment rate) represent the change in first-year BA students by 1,000 due to a 1-percentage-point change in these shares. All other coefficients can be interpreted as the change in first-year BA students by 1,000 due to a $1 \%$ change in the respective variable. Robust standard errors are clustered at the level of labor market regions and shown in parentheses. Significance level: ${ }^{* * *} \mathrm{p}<0.01,{ }^{* *} \mathrm{p}<0.05,{ }^{*} \mathrm{p}<0.1$. 
Table 2: Baseline effects of first-year BA students

\begin{tabular}{|c|c|c|c|c|}
\hline & \multicolumn{3}{|c|}{ New highly educated apprentices } & \multirow{2}{*}{$\begin{array}{c}\text { Mean } \\
2011\end{array}$} \\
\hline & $(1)$ & $(2)$ & $(3)$ & \\
\hline \multicolumn{5}{|l|}{ Panel A. Total } \\
\hline First-year BA stud & $\begin{array}{c}-0.0268^{*} \\
(0.0153)\end{array}$ & $\begin{array}{c}-0.0288^{*} \\
(0.0154)\end{array}$ & $\begin{array}{c}-0.0531^{* * *} \\
(0.0169)\end{array}$ & 2,628 \\
\hline \multicolumn{5}{|l|}{ Panel B. Males } \\
\hline Male first-year BA stud & $\begin{array}{c}-0.0506^{* *} \\
(0.0204)\end{array}$ & $\begin{array}{c}-0.0485^{* * *} \\
(0.0186)\end{array}$ & $\begin{array}{c}-0.0546^{* *} \\
(0.0229)\end{array}$ & 1,488 \\
\hline \multicolumn{5}{|l|}{ Panel C. Females } \\
\hline Female first-year BA stud & $\begin{array}{l}-0.0076 \\
(0.0110)\end{array}$ & $\begin{array}{l}-0.0109 \\
(0.0124)\end{array}$ & $\begin{array}{c}-0.0379^{*} \\
(0.0214)\end{array}$ & 1,139 \\
\hline Observations & 2,115 & 2,115 & 2,115 & \\
\hline Region FE & $\mathrm{x}$ & $\mathrm{x}$ & $\mathrm{x}$ & \\
\hline Year FE & $\mathrm{x}$ & $\mathrm{x}$ & $\mathrm{x}$ & \\
\hline Reg. controls & & $\mathrm{x}$ & $\mathrm{x}$ & \\
\hline Region $\times$ time trend & & & $\mathrm{x}$ & \\
\hline \multicolumn{5}{|c|}{$\begin{array}{l}\text { Notes: The table shows the average regional effect of first-year BA students on the number of } \\
\text { new highly educated apprentices. Panel A refers to the total number of new apprentices, Panel } \\
\text { B and C derive from separate regressions for males and females. All models are estimated } \\
\text { with a fixed effects Poisson estimator. Regional controls consist of the variables explained in } \\
\text { Section } 4.2 \text {. Coefficients can be interpreted as semi-elasticities and represent the } \theta \times 100 \% \\
\text { change in new apprentices due to the average regional increase in first-year BA students across } \\
\text { the observation period from 1999-2011, which represents the mean in } 2011 \text { and is shown in } \\
\text { the last column. Robust standard errors are clustered at the level of labor market regions and } \\
\text { shown in parentheses. Significance level: } * * * \mathrm{p}<0.01,{ }^{* *} \mathrm{p}<0.05, * \mathrm{p}<0.1 \text {. }\end{array}$} \\
\hline
\end{tabular}


Table 3: Robustness check for baseline effects: Excl. non-university regions

\begin{tabular}{|c|c|c|c|c|}
\hline & \multicolumn{3}{|c|}{ New highly educated apprentices } & \multirow{2}{*}{$\begin{array}{c}\text { Mean } \\
2011\end{array}$} \\
\hline & $(1)$ & $(2)$ & $(3)$ & \\
\hline \multicolumn{5}{|l|}{ Panel A. Total } \\
\hline First-year BA stud & $\begin{array}{c}-0.0306^{*} \\
(0.0186)\end{array}$ & $\begin{array}{c}-0.0320^{*} \\
(0.0187)\end{array}$ & $\begin{array}{c}-0.0618^{* * *} \\
(0.0206)\end{array}$ & 3,141 \\
\hline \multicolumn{5}{|l|}{ Panel B. Males } \\
\hline Male first-year BA stud & $\begin{array}{c}-0.0603^{* *} \\
(0.0254)\end{array}$ & $\begin{array}{c}-0.0561^{* *} \\
(0.0229)\end{array}$ & $\begin{array}{c}-0.0596^{* *} \\
(0.0284)\end{array}$ & 1,778 \\
\hline \multicolumn{5}{|l|}{ Panel C. Females } \\
\hline Female first-year BA stud & $\begin{array}{l}-0.0086 \\
(0.0135)\end{array}$ & $\begin{array}{l}-0.0120 \\
(0.0154)\end{array}$ & $\begin{array}{c}-0.0451^{*} \\
(0.0269)\end{array}$ & 1,385 \\
\hline Observations Panel A & 1,740 & 1,740 & 1,740 & \\
\hline Observations Panel B & 1,725 & 1,725 & 1,725 & \\
\hline Observations Panel C & 1,725 & 1,725 & 1,725 & \\
\hline Region FE & $\mathrm{x}$ & $\mathrm{x}$ & $\mathrm{x}$ & \\
\hline Year FE & $\mathrm{x}$ & $\mathrm{x}$ & $\mathrm{x}$ & \\
\hline Reg. controls & & $\mathrm{x}$ & $\mathrm{x}$ & \\
\hline Region $\times$ time trend & & & $\mathrm{x}$ & \\
\hline \multicolumn{5}{|c|}{$\begin{array}{l}\text { Notes: The table shows the average regional effect of first-year BA students on the number of } \\
\text { new highly educated apprentices in regions with universities, i.e., excluding those that contain } \\
\text { less than } 50 \text { total first-year students in } 2011 \text {. Panel A refers to the total number of new highly } \\
\text { educated apprentices, Panel B and C derive from separate regressions for males and females. } \\
\text { All models are estimated with a fixed effects Poisson estimator. Regional controls consist } \\
\text { of the variables explained in Section } 4.2 \text {. Coefficients can be interpreted as semi-elasticities } \\
\text { and represent the } \theta \times 100 \% \text { change in new highly educated apprentices due to the average } \\
\text { regional increase in first-year BA students across the observation period from 1999-2011, which } \\
\text { represents the mean in } 2011 \text { and is shown in the last column. Robust standard errors are } \\
\text { clustered at the level of labor market regions and shown in parentheses. Significance level: *** } \\
\mathrm{p}<0.01,{ }^{* *} \mathrm{p}<0.05, * \mathrm{p}<0.1 \text {. }\end{array}$} \\
\hline
\end{tabular}


Table 4: Robustness check for baseline effects: Additional controls

\begin{tabular}{|c|c|c|c|c|}
\hline & \multicolumn{3}{|c|}{ New highly educated apprentices } & \multirow{2}{*}{$\begin{array}{c}\text { Mean } \\
2011\end{array}$} \\
\hline & (1) & $(2)$ & (3) & \\
\hline \multicolumn{5}{|l|}{ Panel A. Total } \\
\hline First-year BA stud & $\begin{array}{c}-0.0268^{*} \\
(0.0153) \\
\end{array}$ & $\begin{array}{c}-0.0224 \\
(0.0154)\end{array}$ & $\begin{array}{c}-0.0557^{* * *} \\
(0.0196) \\
\end{array}$ & 2,628 \\
\hline \multicolumn{5}{|l|}{ Panel B. Males } \\
\hline Male first-year BA stud & $\begin{array}{c}-0.0506^{* *} \\
(0.0204)\end{array}$ & $\begin{array}{c}-0.0472^{* *} \\
(0.0211)\end{array}$ & $\begin{array}{c}-0.0588^{* *} \\
(0.0248)\end{array}$ & 1,488 \\
\hline \multicolumn{5}{|l|}{ Panel C. Females } \\
\hline Female first-year BA stud & $\begin{array}{c}-0.0076 \\
(0.0110)\end{array}$ & $\begin{array}{l}-0.0018 \\
(0.0111)\end{array}$ & $\begin{array}{c}-0.0397^{*} \\
(0.0236)\end{array}$ & 1,139 \\
\hline Observations & 2,115 & 2,115 & 2,115 & \\
\hline Region FE & $\mathrm{x}$ & $\mathrm{x}$ & $\mathrm{x}$ & \\
\hline Year FE & $\mathrm{x}$ & $\mathrm{x}$ & $\mathrm{x}$ & \\
\hline Reg. controls & & $\mathrm{x}$ & $\mathrm{x}$ & \\
\hline Add. controls & & $\mathrm{x}$ & $\mathrm{x}$ & \\
\hline Region $\times$ time trend & & & $\mathrm{x}$ & \\
\hline \multicolumn{5}{|c|}{$\begin{array}{l}\text { Notes: The table shows the average regional effect of first-year BA students on the number of } \\
\text { new highly educated apprentices. Panel A refers to the total number of new highly educated } \\
\text { apprentices, Panel B and C derive from separate regressions for males and females. All models } \\
\text { are estimated with a fixed effects Poisson estimator. Regional controls consist of the variables } \\
\text { explained in Section } 4.2 \text {. Additional controls include the share of employees subject to social } \\
\text { security contributions with academic qualifications, the log GDP per capita, the log population } \\
\text { density, the share of females in the population and the share of foreign-born residents in the } \\
\text { population. Coefficients can be interpreted as semi-elasticities and represent the } \theta \times 100 \% \\
\text { change in new highly educated apprentices due to the average regional increase in first-year } \\
\text { BA students across the observation period from 1999-2011, which represents the mean in } 2011 \\
\text { and is shown in the last column. Robust standard errors are clustered at the level of labor } \\
\text { market regions and shown in parentheses. Significance level: } * * * p<0.01, * * p<0.05, * p<0.1 \text {. }\end{array}$} \\
\hline
\end{tabular}


Table 5: Robustness check for baseline effects: Falsification test

\begin{tabular}{|c|c|c|c|c|}
\hline & \multicolumn{3}{|c|}{ New less-educated apprentices } & \multirow{2}{*}{$\begin{array}{c}\text { Mean } \\
2011\end{array}$} \\
\hline & $(1)$ & $(2)$ & $(3)$ & \\
\hline \multicolumn{5}{|l|}{ Panel A. Total } \\
\hline First-year BA stud & $\begin{array}{c}0.0011 \\
(0.0172)\end{array}$ & $\begin{array}{l}-0.0066 \\
(0.0070)\end{array}$ & $\begin{array}{c}0.0058 \\
(0.0185)\end{array}$ & 2,628 \\
\hline \multicolumn{5}{|l|}{ Panel B. Males } \\
\hline Male first-year BA stud & $\begin{array}{c}0.0135 \\
(0.0172)\end{array}$ & $\begin{array}{c}0.0013 \\
(0.0081)\end{array}$ & $\begin{array}{c}0.0070 \\
(0.0243)\end{array}$ & 1,488 \\
\hline \multicolumn{5}{|l|}{ Panel C. Females } \\
\hline Female first-year BA stud & $\begin{array}{l}-0.0110 \\
(0.0169)\end{array}$ & $\begin{array}{l}-0.0139 \\
(0.0087)\end{array}$ & $\begin{array}{c}0.0104 \\
(0.0148)\end{array}$ & 1,139 \\
\hline Observations & 2,115 & 2,115 & 2,115 & \\
\hline Region FE & $\mathrm{x}$ & $\mathrm{x}$ & $\mathrm{x}$ & \\
\hline Year FE & $\mathrm{x}$ & $\mathrm{x}$ & $\mathrm{x}$ & \\
\hline Reg. controls & & $\mathrm{x}$ & $\mathrm{x}$ & \\
\hline Region $\times$ time trend & & & $\mathrm{x}$ & \\
\hline \multicolumn{5}{|c|}{$\begin{array}{l}\text { Notes: The table shows the average regional effect of first-year BA students on the number } \\
\text { of new less-educated apprentices. Panel A refers to the total number of new less-educated } \\
\text { apprentices, Panel B and C derive from separate regressions for males and females. All models } \\
\text { are estimated with a fixed effects Poisson estimator. Regional controls consist of the variables } \\
\text { explained in Section } 4.2 \text {. Coefficients can be interpreted as semi-elasticities and represent } \\
\text { the } \theta \times 100 \% \text { change in new less-educated apprentices due to the average regional increase } \\
\text { in first-year BA students across the observation period from 1999-2011, which represents the } \\
\text { mean in } 2011 \text { and is shown in the last column. Robust standard errors are clustered at the level } \\
\text { of labor market regions and shown in parentheses. Significance level: } * * * p<0.01, * * p<0.05 \text {, } \\
* \mathrm{p}<0.1 \text {. }\end{array}$} \\
\hline
\end{tabular}




\section{Appendix Figures and Tables}

Figure A-1: Entrants into the post-secondary education system in Germany

Panel A. Absolute

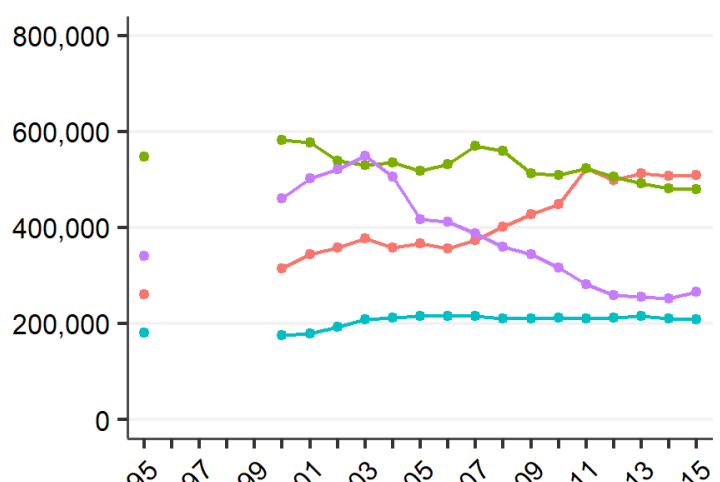

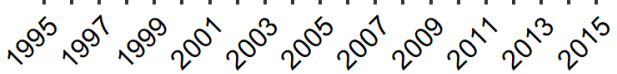

Panel B. Per school leaver

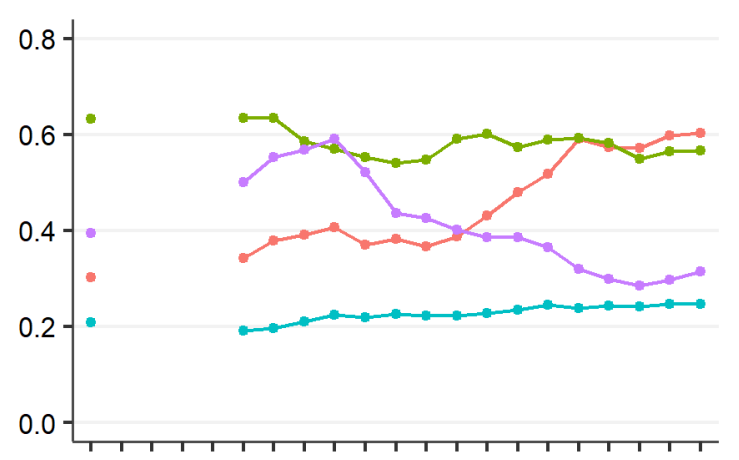

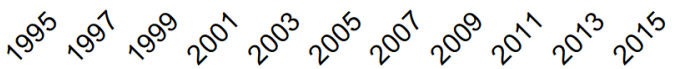

$\because$ students $\rightarrow$ dual apprenticship system $\rightarrow$ full-time vocational schools $\rightarrow$ transition system

Notes: The figure shows new entrants into the academic system (students) and into the three pillars of the VET system (dual apprenticeship system, full-time vocational schools, transition system) across time. Panel A records new entrants in absolute terms, Panel B relates them to the number of school leavers in the respective year. Data provided by Destatis (2018b) and AGER (2018). Calculations by the authors. 
Figure A-2: Presence of universities across regions and time

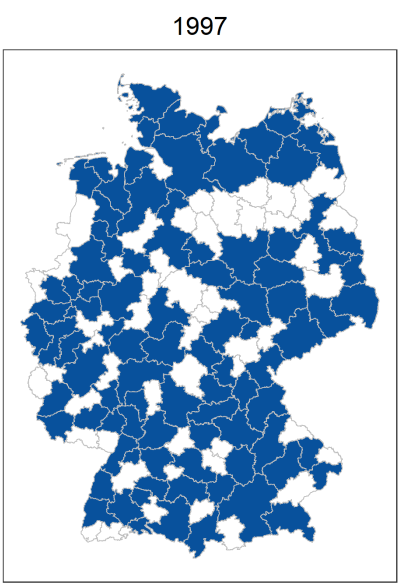

2006

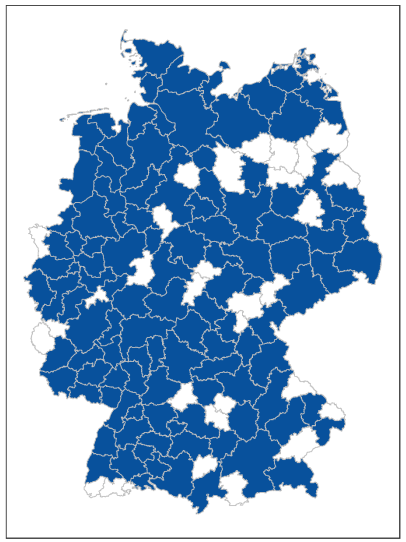

2000

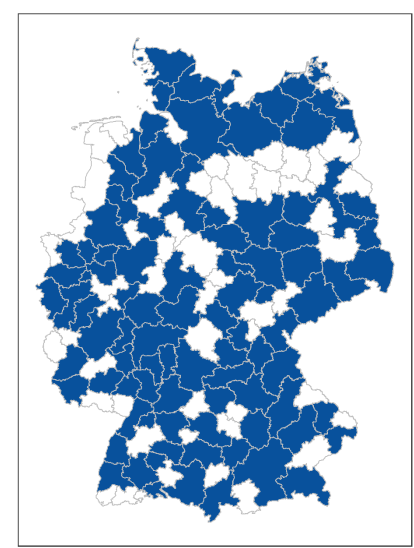

2009

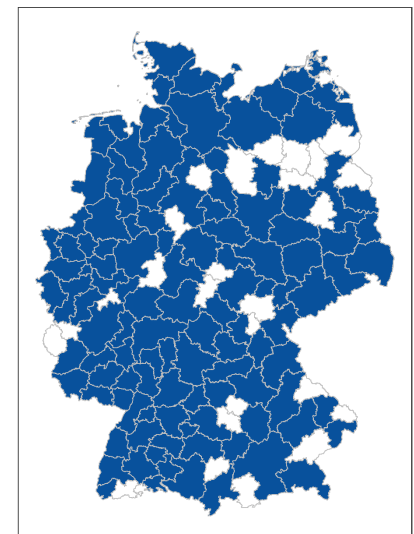

University $\square$ No university
2003

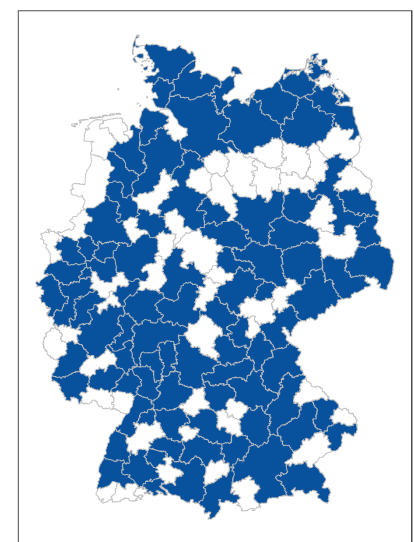

2011

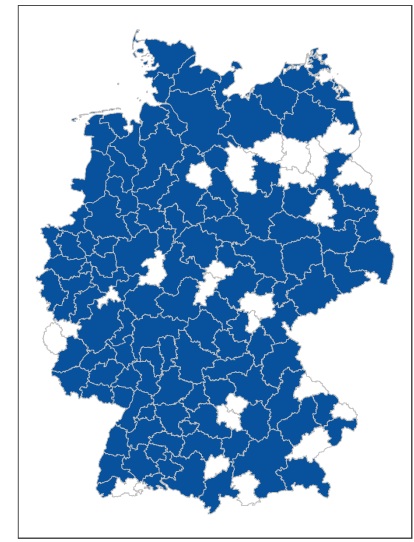

Notes: The figure shows regions with and regions without universities in selected years. Regions without universities are defined as regions with less than 50 total first-year students from universities or universities of applied sciences in the respective year. We use 141 regional labor markets according to Kosfeld and Werner (2012). Geodata is derived from Destatis. 
Figure A-3: Share of first-year BA students by regions and selected years

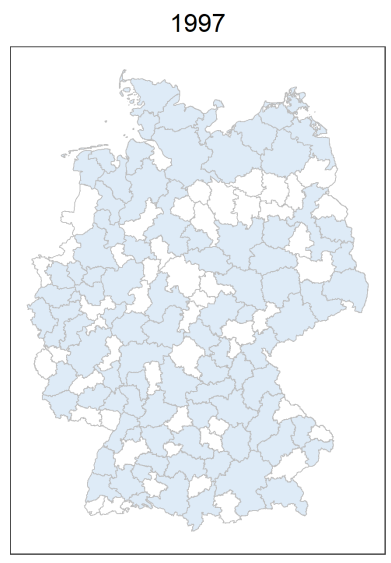

2006

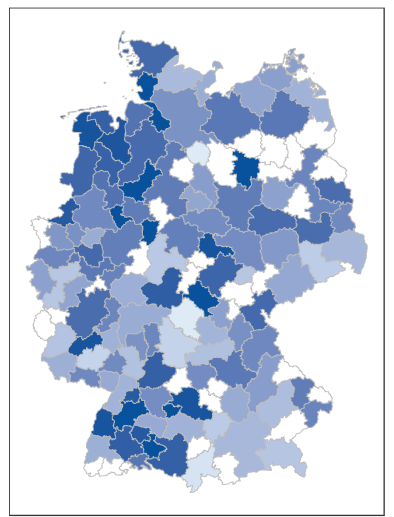

2000

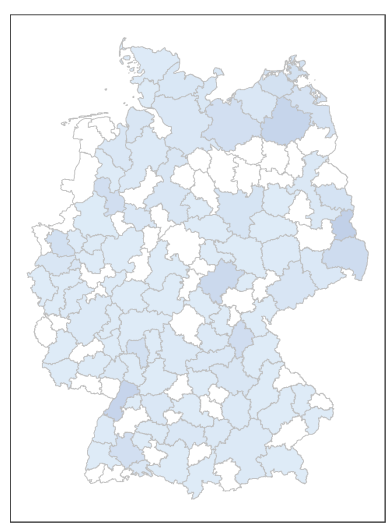

2009

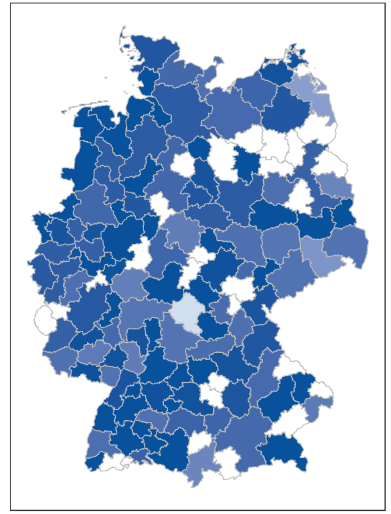

Share of BA first-year students [\%]

\begin{tabular}{l|l|l}
0 & $20-<40$ & $60-<80$
\end{tabular}
2003

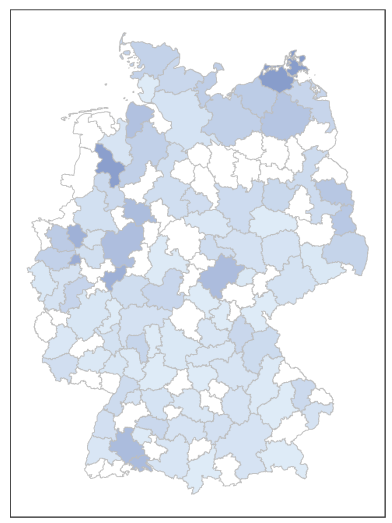

2011

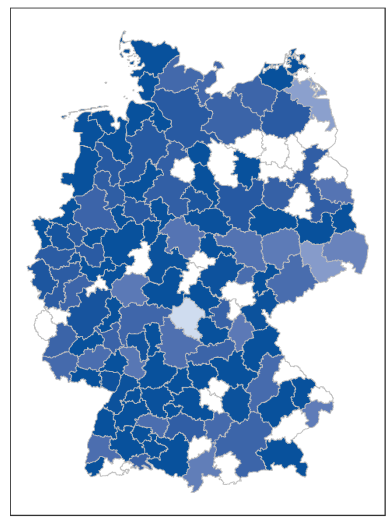

Notes: The figure shows the regional share of first-year BA students per total first-year students studying for BA or former degrees in selected years. White areas reflect regions with less than 50 total first-year students from universities or universities of applied sciences in the respective year. We use 141 regional labor markets according to Kosfeld and Werner (2012). Geodata is derived from Destatis. 
Figure A-4: Robustness check: Additional controls and excl. non-university regions

(a) Males
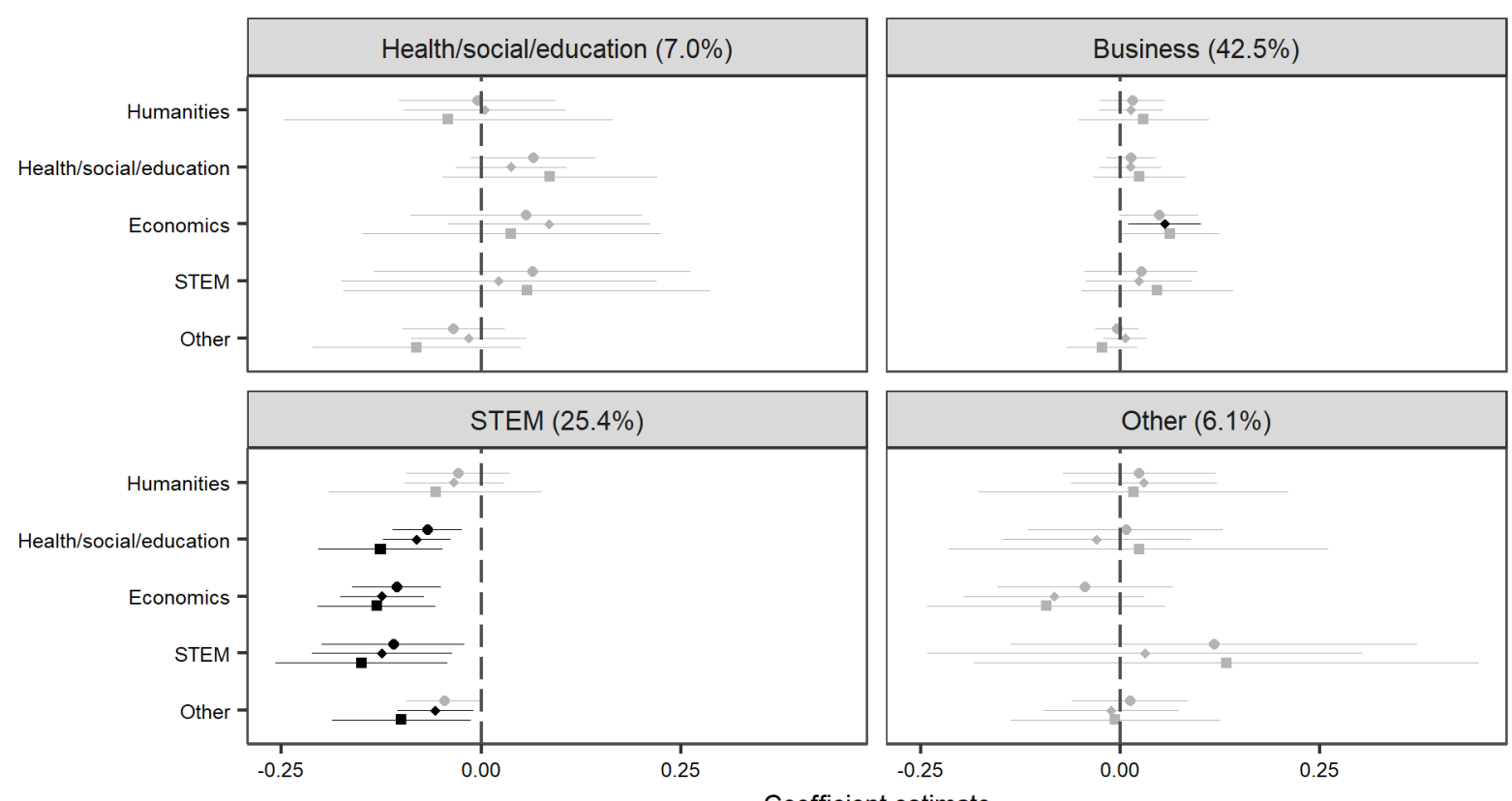

Coefficient estimate

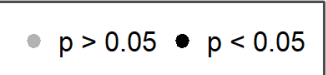

- Baseline - Add. controls - Excl. regions without uni

(b) Females
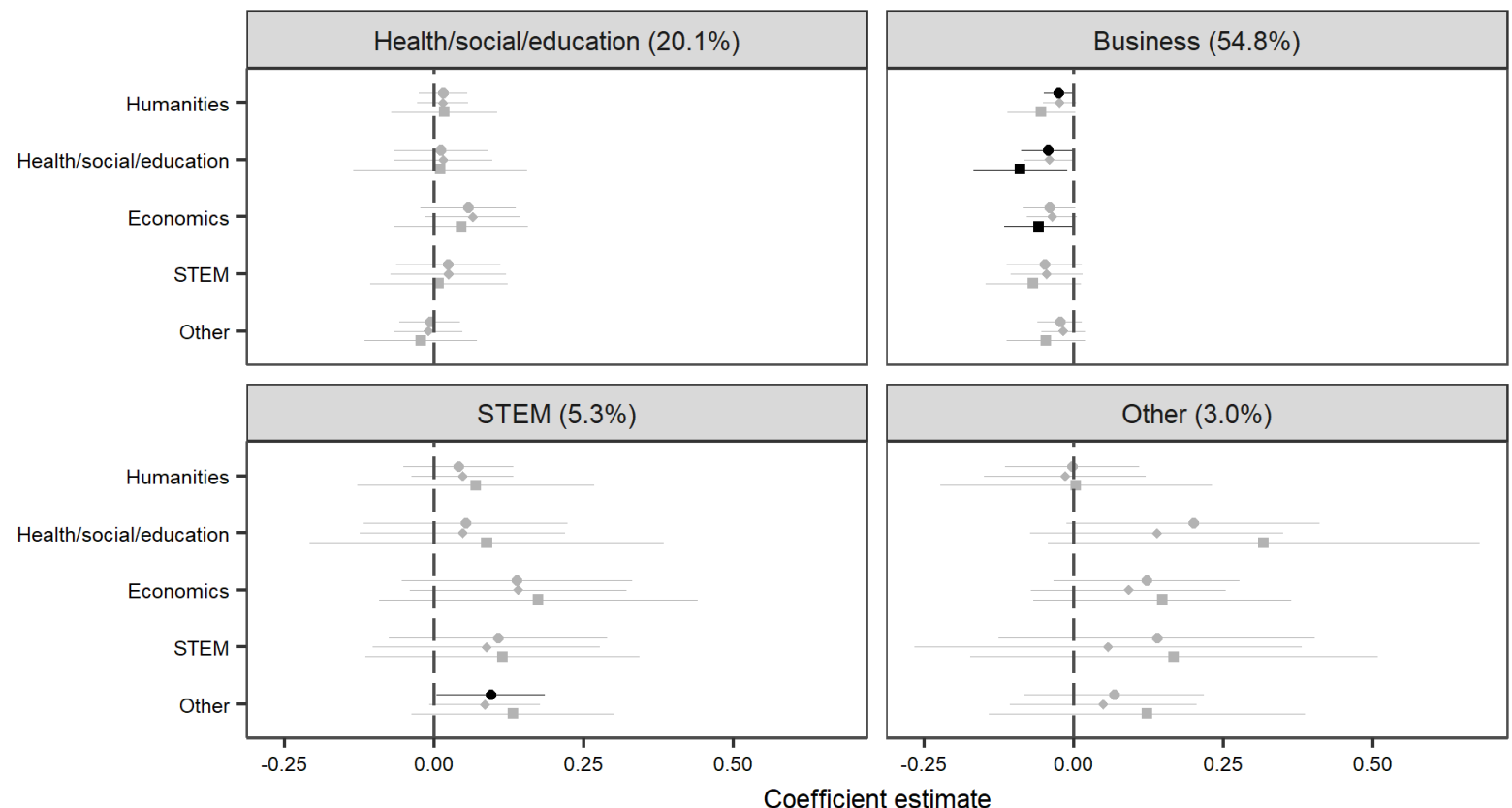

$p>0.05 \bullet p<0.05$

- Baseline - Add. controls - Excl. regions without uni

Notes: The figure shows estimated coefficients and $95 \%$ confidence intervals from estimating equation (2) separately for all $4 \times 5$ combinations of occupational areas and major areas. Coefficients represent the $\theta \times 100 \%$ change in new highly educated apprentices in the respective occupational area (panels) due to the average regional increase in first-year BA students in the respective area of study (y-axis) across the observation period from 1999-2011. o indicates coefficients from the baseline model in our preferred specification (including region and year fixed effects, regional controls and region specific linear time trends). $\diamond$ adds further control variables (see Section 5.3p. $\square$ refers to a subsample of only university regions. Panel A refers to regressions for males, Panel $\mathrm{B}$ for females. Brackets indicate the share of each occupational area in 2010. The remaining share consists of unassigned or missing occupations. Calculations by the authors. 
Figure A-5: Robustness check: Falsification test on new less-educated apprentices

(a) Males
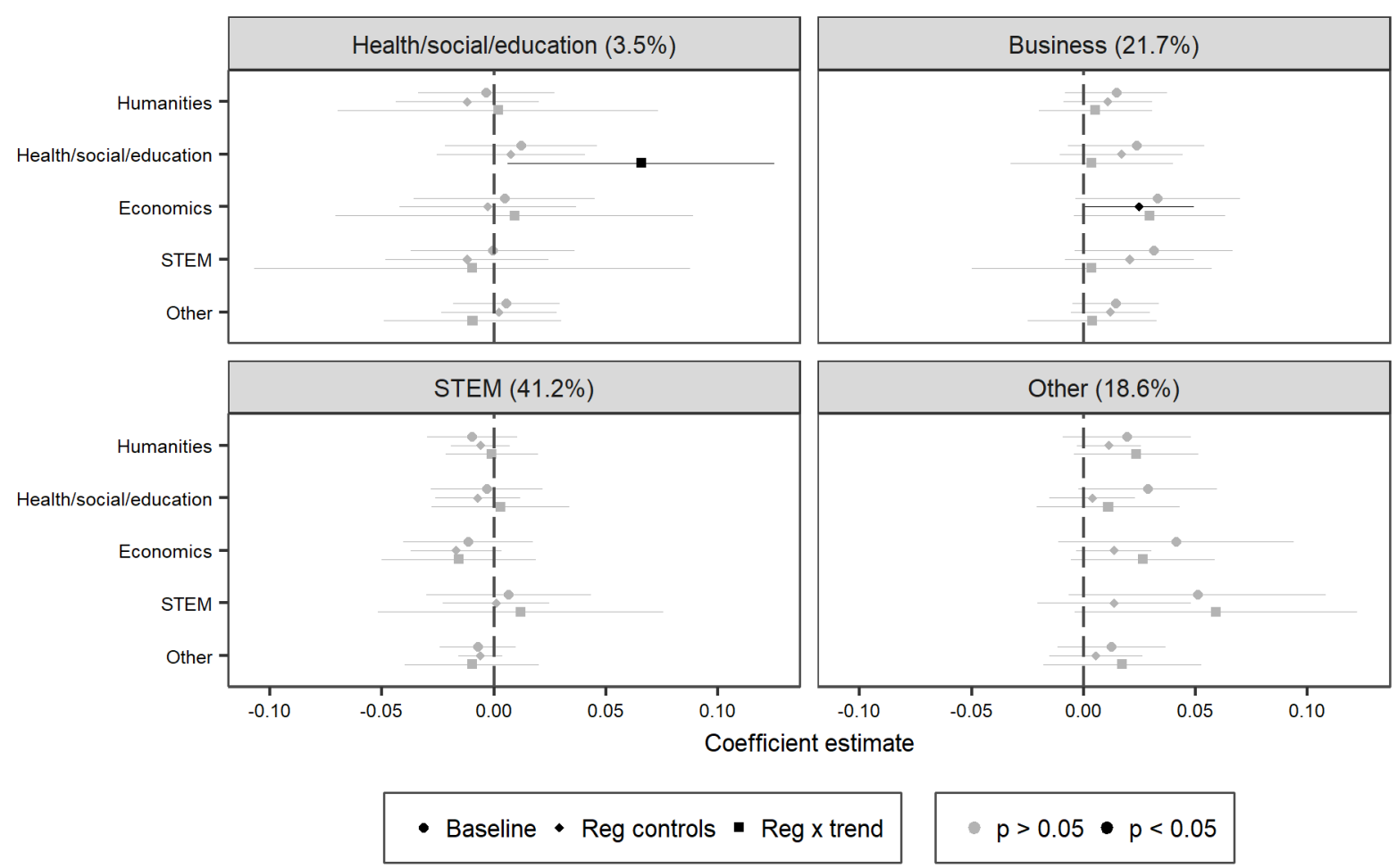

(b) Females
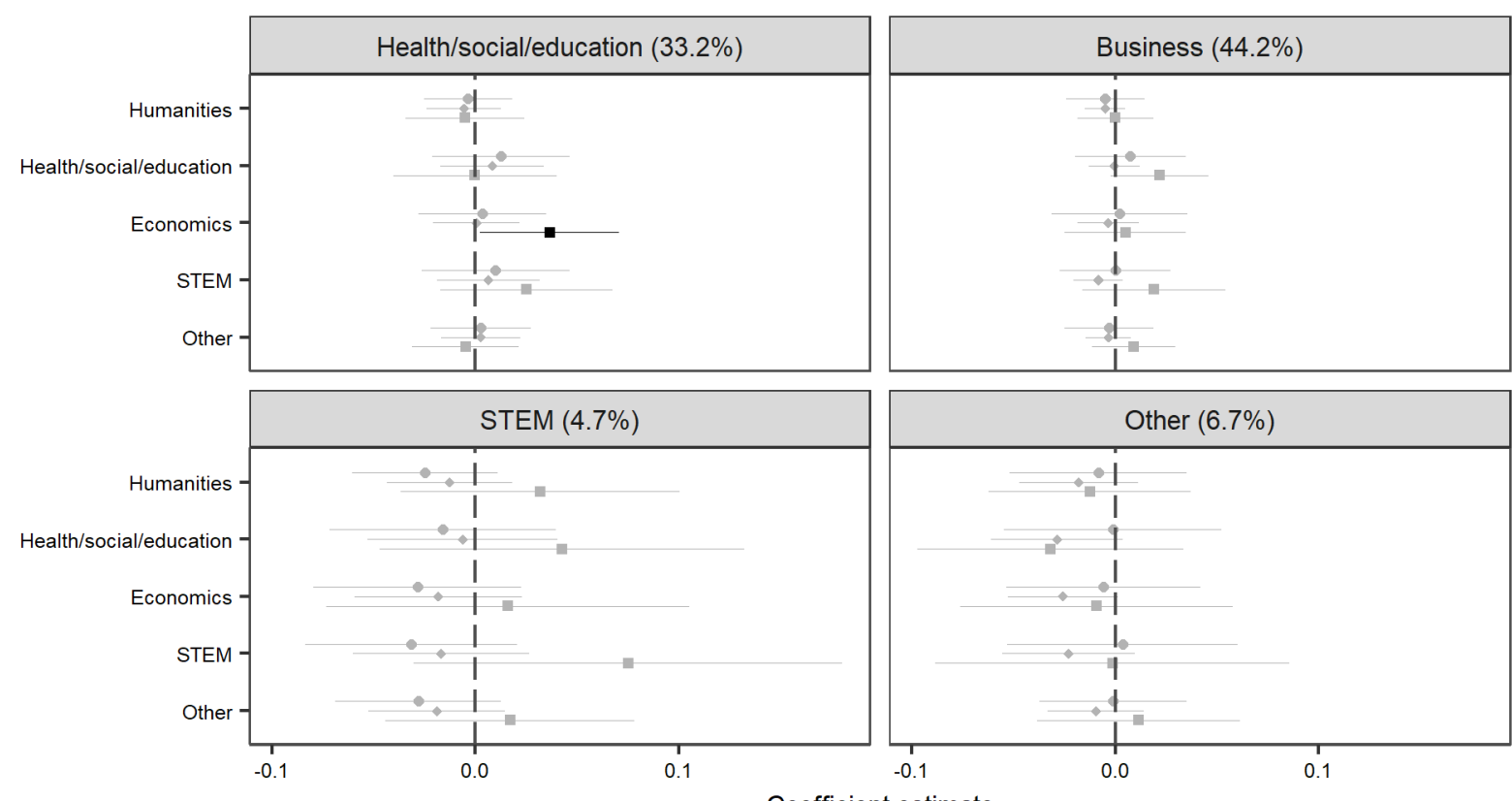

Coefficient estimate

\section{- Baseline - Reg controls - Reg $x$ trend}

Notes: The figure shows estimated coefficients and $95 \%$ confidence intervals from a falsification test for equation (2) using the number of new less-educated apprentices as the dependent variable. Coefficients represent the $\theta \times 100 \%$ change in new less-educated apprentices in the respective occupational area (panels) due to the average regional increase in first-year BA students in the respective area of study (y-axis) across the observation period from 1999-2011. ○ indicates coefficients from the baseline model, including only region and year fixed effects. $\diamond$ adds control variables (see Section 4.2. $\square$ additionally includes a region-specific linear time trend. Panel A refers to regressions for males, Panel B for females. Brackets indicate the share of each occupational area in 2010. The remaining share consists of unassigned or missing occupations. Calculations by the authors. 
Figure A-6: Robustness check: Placebo treatments

(a) Males
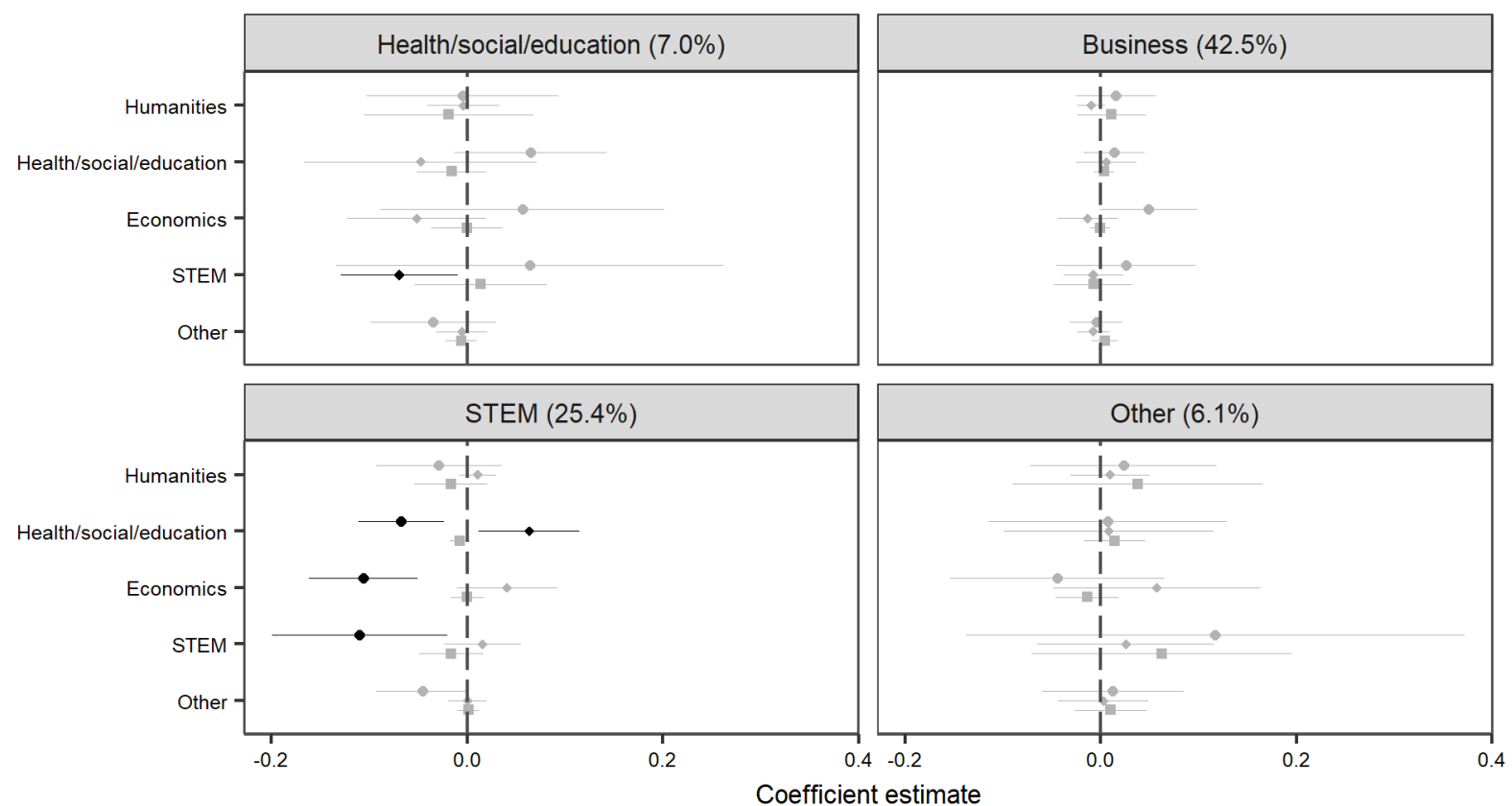

Coefficient estimate

BA - Former degrees - Teaching degrees

$p>0.05 \cdot p<0.05$

(b) Females
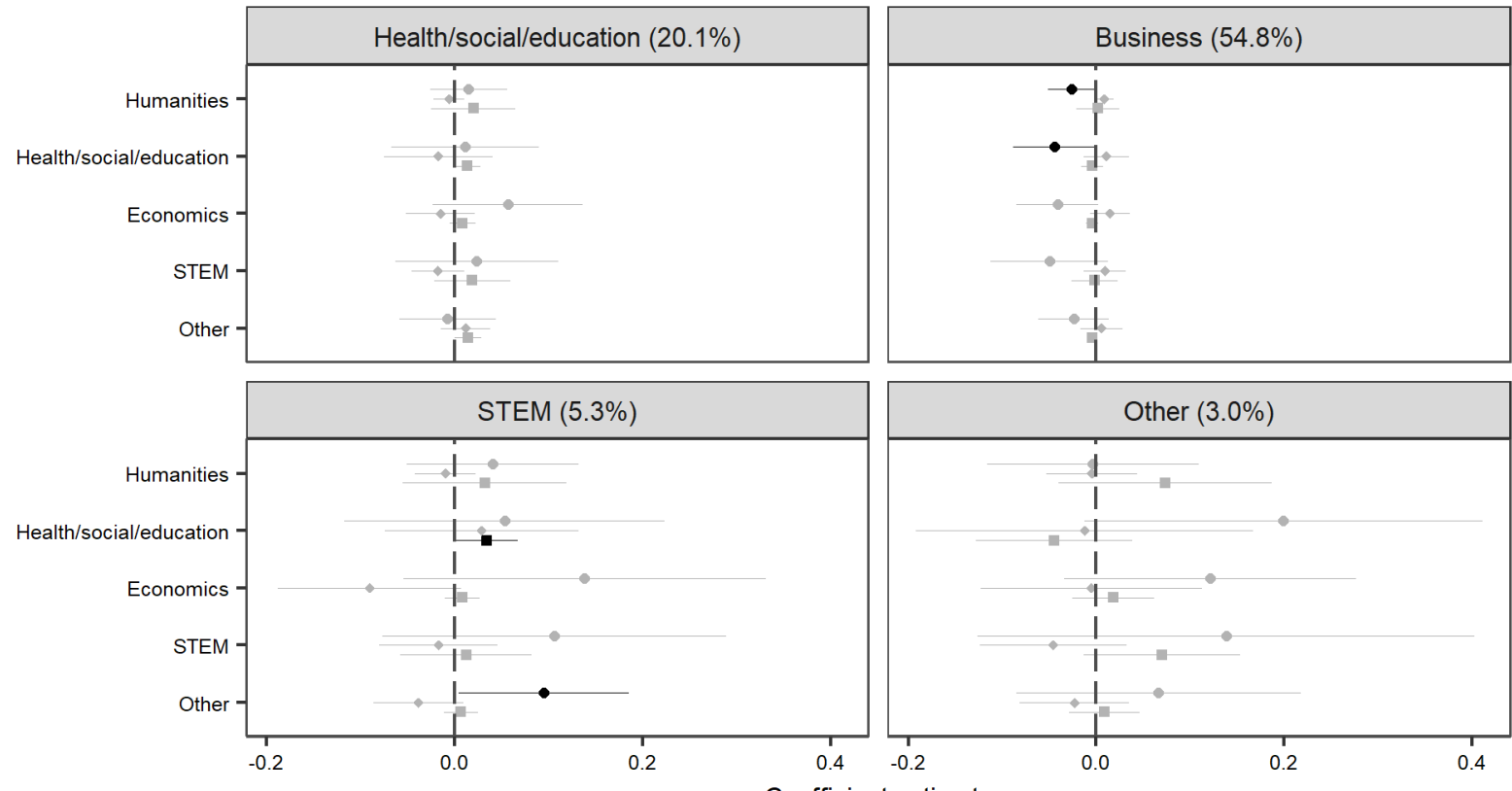

$\operatorname{STEM}(5.3 \%)$

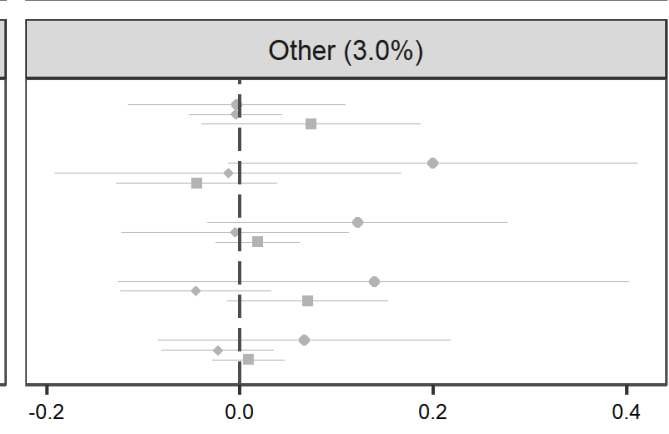

Coefficient estimate

- BA - Former degrees - Teaching degrees

$p>0.05 \cdot p<0.05$

Notes: The figure shows estimated coefficients and $95 \%$ confidence intervals from estimating equation (1) using placebo treatments. Coefficients represent the $\theta \times 100 \%$ change in new highly educated apprentices in the respective occupational area (panels) due to the average regional increase (or decrease with respect to former degrees) in first-year students studying for different types of degrees in the respective area of study (y-axis) across the observation period from 1999-2011. o refers to first-year BA students, $\diamond$ to first-year students studying for former degrees, and $\square$ to first-year students studying for teaching certificates. All models include region and year fixed effects, control variables (see Section 4.2 and region-specific linear time trends. Panel A refers to regressions for males, Panel B for females. Brackets indicate the share of each occupational area in 2010. The remaining share consists of unassigned or missing occupations. Calculations by the authors. 
Table A-1: Assignment of occupational groups to custom occupational areas

\begin{tabular}{|c|c|c|}
\hline $\begin{array}{l}\text { KldB } \\
2010\end{array}$ & Name & Occupational area \\
\hline 111 & Occupations in farming & Other \\
\hline 112 & Occupations in animal husbandry & Other \\
\hline 113 & Occupations in horsekeeping & Other \\
\hline 114 & Occupations in fishing & Other \\
\hline 115 & Occupations in animal care & Other \\
\hline 116 & Occupations in vini- and viticulture & Other \\
\hline 117 & Occupations in forestry, hunting and landscape preservation & Other \\
\hline 121 & Occupations in gardening & Other \\
\hline 122 & Occupations in floristry & Other \\
\hline 211 & Occupations in underground and surface mining and blasting engineering & STEM \\
\hline 212 & Conditioning and processing of natural stone and minerals, production of building materials & STEM \\
\hline 213 & Occupations in industrial glass-making and -processing & STEM \\
\hline 214 & Occupations in industrial ceramic-making and -processing & STEM \\
\hline 221 & Occupations in plastic- and rubber-making and -processing & STEM \\
\hline 222 & Occupations in colour coating and varnishing & STEM \\
\hline 223 & Occupations in wood-working and -processing & STEM \\
\hline 231 & Technical occupations in paper-making and -processing and packaging & STEM \\
\hline 232 & Occupations in technical media design & STEM \\
\hline 233 & Occupations in photography and photographic technology & Other \\
\hline 234 & Occupations in printing technology, print finishing, and book binding & STEM \\
\hline 241 & Occupations in metal-making & STEM \\
\hline 242 & Occupations in metalworking & STEM \\
\hline 243 & Occupations in treatment of metal surfaces & STEM \\
\hline 244 & Occupations in metal constructing and welding & STEM \\
\hline 245 & Occupations in precision mechanics and tool making & STEM \\
\hline 251 & Occupations in machine-building and -operating & STEM \\
\hline 252 & Technical occupations in the automotive, aeronautic, aerospace and ship building industries & STEM \\
\hline 261 & Occupations in mechatronics, automation and control technology & STEM \\
\hline 262 & Technical occupations in energy technologies & STEM \\
\hline 263 & Occupations in electrical engineering & STEM \\
\hline 271 & Occupations in technical research and development & STEM \\
\hline 272 & Draftspersons, technical designers, and model makers & STEM \\
\hline 273 & Technical occupations in production planning and scheduling & STEM \\
\hline 281 & Occupations in textile making & STEM \\
\hline 282 & Occupations in the production of clothing and other textile products & Other \\
\hline 283 & Occupations in leather- and fur-making and -processing & Other \\
\hline 291 & Occupations in beverage production & Other \\
\hline 292 & Occupations in the production of foodstuffs, confectionery and tobacco products & Other \\
\hline 293 & Cooking occupations & Other \\
\hline 311 & Occupations in construction scheduling and supervision, and architecture & STEM \\
\hline 312 & Occupations in surveying and cartography & STEM \\
\hline 321 & Occupations in building construction & Other \\
\hline 322 & Occupations in civil engineering & Other \\
\hline 331 & Floor layers & Other \\
\hline 332 & Painters, varnishers, plasterers, occup. in waterproof. of build., preserv. of struct. \& wooden build. comp. & Other \\
\hline 333 & Occup. in the interior constr. \& dry walling, insulation, carpentry, glazing, roller shutter \& jalousie inst. & STEM \\
\hline 341 & Occupations in building services engineering & STEM \\
\hline 342 & Occupations in plumping, sanitation, heating, ventilating, and air conditioning & STEM \\
\hline 343 & Occupations in building services and waste disposal & STEM \\
\hline 411 & Occupations in mathematics and statistics & STEM \\
\hline 412 & Occupations in biology & STEM \\
\hline 413 & Occupations in chemistry & STEM \\
\hline 414 & Occupations in physics & STEM \\
\hline 421 & Occupations in geology, geography and meteorology & STEM \\
\hline 422 & Occupations in environmental protection engineering & STEM \\
\hline 423 & Occupations in environmental protection management and environmental protection consulting & STEM \\
\hline 431 & Occupations in computer science & STEM \\
\hline 432 & Occupations in IT-system-analysis, IT-application-consulting and IT-sales & STEM \\
\hline 433 & Occupations in IT-network engineering, IT-coordination, IT-administration and IT-organisation & STEM \\
\hline 434 & Occupations in software development and programming & STEM \\
\hline 511 & Technical occupations in railway, aircraft and ship operation & Other \\
\hline 512 & Occupations in the inspection and maintenance of traffic infrastructure & Other \\
\hline 513 & Occupations in warehousing and logistics, in postal and other delivery services, and in cargo handling & Business, Trade, Services \\
\hline 514 & Service occupations in passenger traffic & Other \\
\hline 515 & Occupations in traffic surveillance and control & Other \\
\hline 516 & Management assistants in transport and logistics & Business, Trade, Services \\
\hline 521 & Driver of vehicles in road traffic & Other \\
\hline 522 & Drivers of vehicles in railway traffic & Other \\
\hline 523 & Aircraft pilots & Other \\
\hline 524 & Ship's officers and masters & Other \\
\hline 525 & Drivers and operators of construction and transportation vehicles and equipment & Other \\
\hline 531 & Occupations in physical security, personal protection, fire protection and workplace safety & Other \\
\hline 532 & Occupations in police and criminal investigation, jurisdiction and the penal institution & Other \\
\hline 533 & Occupations in occupational health and safety administration, public health authority, and disinfection & Other \\
\hline 541 & Occupations in cleaning services & Other \\
\hline 611 & Occupations in purchasing and sales & Business, Trade, Services \\
\hline 612 & Trading occupations & Business, Trade, Services \\
\hline 613 & Occupations in real estate and facility management & Business, Trade, Services \\
\hline 621 & Sales occupations in retail trade (without product specialisation) & Business, Trade, Services \\
\hline 622 & Sales occup. (retail trade) selling clothing, electronic devices, furniture, motor vehicles and other durables & Business, Trade, Services \\
\hline 623 & Sales occupations (retail) selling foodstuffs & Business, Trade, Services \\
\hline 624 & Sales occup. (retail) selling drugstore products, pharmaceuticals, medical supplies and healthcare goods & Business, Trade, Services \\
\hline 625 & Sales occupations (retail) selling books, art, antiques, musical instruments, recordings or sheet music & Business, Trade, Services \\
\hline 631 & Occupations in tourism and the sports (and fitness) industry & Business, Trade, Services \\
\hline 632 & Occupations in hotels & Business, Trade, Services \\
\hline 633 & Gastronomy occupations & Business, Trade, Services \\
\hline 634 & Occupations in event organisation and management & Business, Trade, Services \\
\hline 711 & Managing directors and executive board members & Business, Trade, Services \\
\hline 712 & Legislators and senior officials of special interest organisations & Business, Trade, Services \\
\hline 713 & Occupations in business organisation and strategy & Business, Trade, Services \\
\hline 714 & Office clerks and secretaries & Business, Trade, Services \\
\hline 715 & Occupations in human resources management and personnel service & Business, Trade, Services \\
\hline 721 & Occupations in insurance and financial services & Business, Trade, Services \\
\hline
\end{tabular}


Table A-1: Assignment of occupational groups to custom occupational areas (cont.)

\begin{tabular}{|c|c|c|}
\hline $\begin{array}{l}\text { KldB } \\
2010\end{array}$ & Name & Occupational area \\
\hline 722 & Occupations in accounting, controlling and auditing & Business, Trade, Services \\
\hline 723 & Occupations in tax consultancy & Business, Trade, Services \\
\hline 731 & Occupations in legal services, jurisdiction, and other officers of the court & Business, Trade, Services \\
\hline 732 & Occupations in public administration & Business, Trade, Services \\
\hline 733 & Occupations in media, documentation and information services & Business, Trade, Services \\
\hline 811 & Doctors' receptionists and assistants & Health/social work/education \\
\hline 812 & Laboratory occupations in medicine & Health/social work/education \\
\hline 813 & Occupations in nursing, emergency medical services and obstetrics & Health/social work/education \\
\hline 814 & Occupations in human medicine and dentistry & Health/social work/education \\
\hline 815 & Occupations in veterinary medicine and non-medical animal health practitioners & Health/social work/education \\
\hline 816 & Occupations in psychology and non-medical psychotherapy & Health/social work/education \\
\hline 817 & Occupations in non-medical therapy and alternative medicine & Health/social work/education \\
\hline 818 & Occupations in pharmacy & Health/social work/education \\
\hline 821 & Occupations in geriatric care & Health/social work/education \\
\hline 822 & Occupations providing nutritional advice or health counselling, and occupations in wellness & Health/social work/education \\
\hline 823 & Occupations in body care & Health/social work/education \\
\hline 824 & Occupations in funeral services & Other \\
\hline 825 & Technical occupations in medicine, orthopaedic and rehabilitation & STEM \\
\hline 831 & Occupations in education and social work, and pedagogic specialists in social care work & Health/social work/education \\
\hline 832 & Occupations in housekeeping and consumer counselling & Health/social work/education \\
\hline 833 & Occupations in theology and church community work & Health/social work/education \\
\hline 841 & Teachers in schools of general education & Health/social work/education \\
\hline 842 & Teachers for occupation-specific subjects at vocational schools and in-company instructors in voc. training & Health/social work/education \\
\hline 843 & Teachers and researcher at universities and colleges & Health/social work/education \\
\hline 844 & Teachers at educational institutions other than schools (except driving, flying and sports instructors) & Health/social work/education \\
\hline 845 & Driving, flying and sports instructors at educational institutions other than schools & Other \\
\hline 911 & Occupations in philology & Other \\
\hline 912 & Occupations in the humanities & Other \\
\hline 913 & Occupations in the social sciences & Other \\
\hline 914 & Occupations in economics & Business, Trade, Services \\
\hline 921 & Occupations in advertising and marketing & Business, Trade, Services \\
\hline 922 & Occupations in public relations & Business, Trade, Services \\
\hline 923 & Occupations in publishing and media management & Business, Trade, Services \\
\hline 924 & Occupations in editorial work and journalism & Business, Trade, Services \\
\hline 931 & Occupations in product and industrial design & Other \\
\hline 932 & Occupations in interior design, visual marketing, and interior decoration & Other \\
\hline 933 & Occupations in artisan craftwork and fine arts & Other \\
\hline 934 & Artisans designing ceramics and glassware & Other \\
\hline 935 & Artisans working with metal & Other \\
\hline 936 & Occupations in musical instrument making & Other \\
\hline 941 & Musicians, singers and conductors & Other \\
\hline 942 & Actors, dancers, athletes and related occupations & Other \\
\hline 943 & Presenters and entertainers & Other \\
\hline 944 & Occupations in theatre, film and television productions & Other \\
\hline 945 & Occupations in event technology, cinematography, and sound engineering & Other \\
\hline 946 & Occupations in stage, costume and prop design & Other \\
\hline 947 & Technical and management occupations in museums and exhibitions & Other \\
\hline
\end{tabular}

Notes: The table shows the assignment of official occupational groups according to the KldB 2010 of the Federal Employment Agency to custom occupational areas. 
Table A-2: Assignment of fields of study to custom areas of study

\begin{tabular}{|c|c|c|}
\hline Code & Name & Area of study \\
\hline 01 & General Linguistics and Cultural Studies & Humanities \\
\hline 02 & Protestant Theology, Protes. Religious Education & Humanities \\
\hline 03 & Catholic Theology, Catholic Religious Education & Humanities \\
\hline 04 & Philosophy & Humanities \\
\hline 05 & History & Humanities \\
\hline 06 & Library Scien., Documentation Science & Humanities \\
\hline 07 & General Literary Studies, General Linguistics & Humanities \\
\hline 08 & Classical Philology, Modern Greek & Humanities \\
\hline 09 & German Studies/German & Humanities \\
\hline 10 & English Studies, American Studies & Humanities \\
\hline 11 & Romance Studies & Humanities \\
\hline 12 & Slavic Studies, Baltic Studies, Finno-Ugrian Studies & Humanities \\
\hline 13 & Non-Europ. Lang. and Cult. Studies & Humanities \\
\hline 14 & Cultural Studies & Humanities \\
\hline 17 & Special Needs Education & Health/social work/education \\
\hline 18 & Islamic Studies & Humanities \\
\hline 22 & Sports, Sports Science & unassigned \\
\hline 23 & General Social Studies & Other \\
\hline 24 & Regional Studies & Other \\
\hline 25 & Political Science & Other \\
\hline 26 & Social Science & Other \\
\hline 27 & Applied Social Science & Health/social work/education \\
\hline 28 & Law & unassigned \\
\hline 29 & Administrative Science & Other \\
\hline 30 & Business and Economics & Economics \\
\hline 31 & Business Engineering specialising in Economics & Economics \\
\hline 32 & Psychology & Health/social work/education \\
\hline 33 & Educational Science & Health/social work/education \\
\hline 36 & Mathematics, General Natural Sciences & STEM \\
\hline 37 & Mathematics & STEM \\
\hline 39 & Physics, Astronomy & STEM \\
\hline 40 & Chemistry & STEM \\
\hline 41 & Pharmacy & unassigned \\
\hline 42 & Biology & STEM \\
\hline 43 & Geosciences (excluding Geography) & STEM \\
\hline 44 & Geography & STEM \\
\hline 48 & General Health Science & Health/social work/education \\
\hline 49 & Medicine (General Medicine) & unassigned \\
\hline 50 & Dentistry & unassigned \\
\hline 51 & Veterinary Medicine & unassigned \\
\hline 57 & Land Management Engineering/Landscape Design & Other \\
\hline 58 & Agricultural Science, Food and Beverage Technology & Other \\
\hline 59 & Forest Science, Wood Science & Other \\
\hline 60 & Nutritional and Domestic Sciences & Other \\
\hline 61 & General Engineering & STEM \\
\hline 62 & Mining, Metallurgy & STEM \\
\hline 63 & Mechanical Engineering, Process Engineering & STEM \\
\hline 64 & Electrical Engineering, Information Engineering & STEM \\
\hline 65 & Transport Technology, Nautical Science & STEM \\
\hline 66 & Architecture, Interior Architecture & STEM \\
\hline 67 & Spatial Planning & STEM \\
\hline 68 & Civil Engineering & STEM \\
\hline 69 & Surveying & STEM \\
\hline 70 & Business Engineering spec. in Engineering Sciences & STEM \\
\hline 71 & Computer Science & STEM \\
\hline 72 & Materials Engineering and Technology & STEM \\
\hline 74 & General Art, Art Theory & unassigned \\
\hline 75 & Fine Arts & unassigned \\
\hline 76 & Design & unassigned \\
\hline 77 & Performing Arts, Film and Television Studies, Theatre Studies & unassigned \\
\hline 78 & Music, Musicology & unassigned \\
\hline 83 & Outside the study area classification & unassigned \\
\hline
\end{tabular}

Notes: The table shows the assignment of official fields of study according to the Fächersystematik of Destatis to custom areas of study. A few majors, where state examinations - and not BA or MA degrees-are still common, remain unassigned. 
Table A-3: Main descriptives for the regional share of first-year BA students per year

\begin{tabular}{cccccc}
\hline \hline Year & $\mathrm{N}$ & Mean & SD & Min & Max \\
\hline 1997 & 90 & 0.000 & 0.000 & 0.000 & 0.000 \\
1998 & 91 & 0.000 & 0.000 & 0.000 & 0.000 \\
1999 & 92 & 0.692 & 1.675 & 0.000 & 9.868 \\
2000 & 91 & 1.941 & 3.299 & 0.000 & 16.109 \\
2001 & 92 & 5.385 & 12.174 & 0.000 & 100.000 \\
2002 & 93 & 8.629 & 16.081 & 0.000 & 100.000 \\
2003 & 93 & 11.581 & 16.859 & 0.000 & 100.000 \\
2004 & 91 & 16.586 & 15.330 & 0.000 & 82.182 \\
2005 & 111 & 34.222 & 26.088 & 0.000 & 100.000 \\
2006 & 112 & 58.289 & 27.688 & 0.000 & 100.000 \\
2007 & 112 & 75.028 & 22.266 & 0.000 & 100.000 \\
2008 & 112 & 82.955 & 18.410 & 4.959 & 100.000 \\
2009 & 115 & 86.633 & 16.708 & 8.036 & 100.000 \\
2010 & 115 & 87.539 & 16.251 & 10.619 & 100.000 \\
2011 & 116 & 88.330 & 16.452 & 8.671 & 100.000 \\
2012 & 116 & 89.861 & 14.285 & 36.872 & 100.000 \\
2013 & 116 & 89.949 & 14.317 & 36.944 & 100.000 \\
2014 & 116 & 90.089 & 14.222 & 39.726 & 100.000 \\
\hline
\end{tabular}

Notes: The table shows main summary statistics for the regional share of first-year BA students per year, including number of cases (N), mean, standard deviation (SD), minimum and maximum values. The share of first-year BA students is calculated by dividing first-year BA students by first-year BA students plus first-year students studying for former degrees (e.g., Diplom). Labor market regions with less than 50 total first-year students in the respective year are dropped. Calculations by the authors. 
Table A-4: Main descriptives for regional first-year BA students per year

\begin{tabular}{ccccccc}
\hline \hline Year & $\mathrm{N}$ & Mean & $\mathrm{SD}$ & Min & Max & Sum \\
\hline 1997 & 141 & 0 & 0 & 0 & 0 & 0 \\
1998 & 141 & 0 & 0 & 0 & 0 & 0 \\
1999 & 141 & 13 & 40 & 0 & 285 & 1,890 \\
2000 & 141 & 36 & 85 & 0 & 610 & 5,040 \\
2001 & 141 & 76 & 140 & 0 & 745 & 10,770 \\
2002 & 141 & 130 & 266 & 0 & 2,000 & 18,360 \\
2003 & 141 & 199 & 382 & 0 & 2,755 & 28,100 \\
2004 & 141 & 307 & 529 & 0 & 3,535 & 43,230 \\
2005 & 141 & 614 & 951 & 0 & 7,635 & 86,610 \\
2006 & 141 & 976 & 1,442 & 0 & 11,745 & 137,590 \\
2007 & 141 & 1,478 & 2,093 & 0 & 15,535 & 208,410 \\
2008 & 141 & 1,849 & 2,546 & 0 & 18,035 & 260,665 \\
2009 & 141 & 2,076 & 2,870 & 0 & 20,670 & 292,710 \\
2010 & 141 & 2,187 & 3,074 & 0 & 22,240 & 308,435 \\
2011 & 141 & 2,628 & 3,659 & 0 & 23,995 & 370,610 \\
2012 & 141 & 2,507 & 3,499 & 0 & 24,560 & 353,465 \\
2013 & 141 & 2,576 & 3,569 & 0 & 23,925 & 363,175 \\
2014 & 141 & 2,557 & 3,574 & 0 & 24,170 & 360,520 \\
\hline
\end{tabular}

Notes: The table shows main summary statistics for regional first-year BA students per year, including number of cases $(\mathrm{N})$, mean, standard deviation (SD), minimum and maximum values as well as the sum over all regions. Calculations by the authors. 
Table A-5: Overview of definition and sources of variables used

\begin{tabular}{|c|c|c|}
\hline Variable & Definition & Source \\
\hline New apprentices & absolute & SIAB \\
\hline First-year students & absolute & Destatis; ICE database \\
\hline Total school leaver & absolute & Destatis \\
\hline $\begin{array}{l}\text { School leaver with university entrance } \\
\text { qualification }\end{array}$ & absolute & Destatis \\
\hline $\begin{array}{l}\text { Share of school leavers with university } \\
\text { entrance qualification }\end{array}$ & {$[\%]$} & Destatis \\
\hline Unemployment rate & {$[\%]$} & Destatis; INKAR \\
\hline $\begin{array}{l}\text { Share of persons in employment in the } \\
\text { industry sector (incl. construction) }\end{array}$ & {$[\%]$} & Destatis \\
\hline Population density & {$\left[\right.$ Pop per $\left.\mathrm{km}^{2}\right]$} & Destatis \\
\hline $\begin{array}{l}\text { Share of firms with more than } 250 \\
\text { employees }\end{array}$ & {$[\%]$} & SIAB \\
\hline $\begin{array}{l}\text { Share of employees subject to social } \\
\text { security contributions with academic } \\
\text { qualification }\end{array}$ & {$[\%]$} & Federal Employment Agency \\
\hline GDP per capita & {$[1,000$ euros per pop] } & Destatis \\
\hline Share of females in the population & {$[\%]$} & INKAR \\
\hline $\begin{array}{l}\text { Share of foreign-born residents in the } \\
\text { population }\end{array}$ & {$[\%]$} & INKAR \\
\hline Share of population aged 15 to 18 years & {$[\%]$} & Destatis \\
\hline Share of population aged 18 to 25 years & {$[\%]$} & Destatis \\
\hline $\begin{array}{l}\text { Trainees per } 1,000 \text { employees subject } \\
\text { to social security contributions }\end{array}$ & - & INKAR \\
\hline \multicolumn{3}{|c|}{$\begin{array}{l}\text { Notes: Values for the share of persons in employment in the industry sector (including } \\
\text { construction) were missing for the years } 1997,1998 \text { and } 1999 \text {, and thus were extrapolated in } \\
\text { order to maintain balanced panel data. The same holds for values for the share of employees with } \\
\text { academic qualifications, which were extrapolated for the years } 1997 \text { and } 1998 \text { and interpolated } \\
\text { for the year 2011. }\end{array}$} \\
\hline
\end{tabular}


Table A-6: Anticipation effects

\begin{tabular}{|c|c|c|c|}
\hline & Log sl w ueq & Share sl w ueq & Share pop $15-18$ \\
\hline & (1) & $(2)$ & (3) \\
\hline \multirow[t]{2}{*}{ First-year BA stud $t$} & -0.006 & -0.090 & 0.012 \\
\hline & $(0.004)$ & $(0.093)$ & $(0.015)$ \\
\hline \multirow[t]{2}{*}{ First-year BA stud $t+1$} & -0.002 & -0.053 & 0.015 \\
\hline & $(0.003)$ & $(0.088)$ & $(0.018)$ \\
\hline \multirow[t]{2}{*}{ First-year BA stud ${ }_{t+2}$} & -0.002 & -0.128 & 0.022 \\
\hline & $(0.003)$ & $(0.097)$ & $(0.021)$ \\
\hline Observations & 2,115 & 2,115 & 2,115 \\
\hline Reg and Year FE & $\mathrm{x}$ & $\mathrm{x}$ & $\mathrm{x}$ \\
\hline Reg Controls & $\mathrm{x}$ & $\mathrm{x}$ & $\mathrm{x}$ \\
\hline
\end{tabular}

Notes: The table reports estimates from regressing the log number of school leavers with university entrance qualification ( $\log \mathrm{sl} \mathrm{w}$ ueq), the share of school leavers with university entrance qualification (share sl ueq) and the share of the population aged 15 to 18 (share pop 15-18) on the number of first-year BA students in year $t$, year $t+1$ and year $t+2$. All coefficients on shares represent the one percentage point effect of an increase in first-year BA students by 1,000 , the coefficient on logs the $x \times 100 \%$ effect respectively. All models include region and year fixed effects as well as the set of regional controls explained in Section 4.2. Robust standard errors are clustered at the level of labor market regions and shown in parentheses. Significance level: $* * * \mathrm{p}<0.01,{ }^{* *} \mathrm{p}<0.05,{ }^{*} \mathrm{p}<0.1$. 
Table A-7: Detailed results for occupation-specific effects without controls and region-specific linear time trends

\begin{tabular}{|c|c|c|c|c|c|}
\hline \multirow{2}{*}{$\begin{array}{l}\text { First-year BA } \\
\text { students in... }\end{array}$} & HSE & Business & STEM & Other & \multirow{2}{*}{$\begin{array}{l}\text { Mean } \\
2011\end{array}$} \\
\hline & (1) & (2) & (3) & (4) & \\
\hline \multicolumn{6}{|l|}{ Panel A. Total } \\
\hline Humanities & $\begin{array}{c}0.0131 \\
(0.0147)\end{array}$ & $\begin{array}{l}-0.0036 \\
(0.0075)\end{array}$ & $\begin{array}{l}-0.0156 \\
(0.0107)\end{array}$ & $\begin{array}{l}-0.0122 \\
(0.0267)\end{array}$ & 230 \\
\hline Health/social/educ. & $\begin{array}{c}0.0089 \\
(0.0162)\end{array}$ & $\begin{array}{c}-0.0241^{* *} \\
(0.0103)\end{array}$ & $\begin{array}{c}-0.0370^{*} \\
(0.0190)\end{array}$ & $\begin{array}{l}-0.0611 \\
(0.0396)\end{array}$ & 240 \\
\hline Economics & $\begin{array}{c}0.0177 \\
(0.0169)\end{array}$ & $\begin{array}{l}-0.0105 \\
(0.0092)\end{array}$ & $\begin{array}{c}-0.0524^{* * *} \\
(0.0181)\end{array}$ & $\begin{array}{l}-0.0291 \\
(0.0390)\end{array}$ & 593 \\
\hline STEM & $\begin{array}{c}0.0112 \\
(0.0236)\end{array}$ & $\begin{array}{l}-0.0136 \\
(0.0141)\end{array}$ & $\begin{array}{c}-0.0661^{* * *} \\
(0.0191)\end{array}$ & $\begin{array}{l}-0.0289 \\
(0.0405)\end{array}$ & 1184 \\
\hline Other & $\begin{array}{l}-0.0128 \\
(0.0208)\end{array}$ & $\begin{array}{c}-0.0165^{* *} \\
(0.0082)\end{array}$ & $\begin{array}{l}-0.0219 \\
(0.0134)\end{array}$ & $\begin{array}{l}-0.0088 \\
(0.0254)\end{array}$ & 160 \\
\hline \multicolumn{6}{|l|}{ Panel B. Males } \\
\hline Humanities & $\begin{array}{l}-0.0217 \\
(0.0212)\end{array}$ & $\begin{array}{c}0.0094 \\
(0.0127)\end{array}$ & $\begin{array}{c}-0.0357^{* * *} \\
(0.0136)\end{array}$ & $\begin{array}{l}-0.0431 \\
(0.0315)\end{array}$ & 70 \\
\hline Health/social/educ. & $\begin{array}{c}0.0096 \\
(0.0219)\end{array}$ & $\begin{array}{l}-0.0215 \\
(0.0152)\end{array}$ & $\begin{array}{c}-0.0475^{* *} \\
(0.0200)\end{array}$ & $\begin{array}{c}-0.1010^{* *} \\
(0.0476)\end{array}$ & 49 \\
\hline Economics & $\begin{array}{c}0.0076 \\
(0.0264)\end{array}$ & $\begin{array}{c}0.0034 \\
(0.0173)\end{array}$ & $\begin{array}{c}-0.0799^{* * *} \\
(0.0238)\end{array}$ & $\begin{array}{l}-0.0609 \\
(0.0470)\end{array}$ & 313 \\
\hline STEM & $\begin{array}{c}0.0313 \\
(0.0331)\end{array}$ & $\begin{array}{l}-0.0062 \\
(0.0248)\end{array}$ & $\begin{array}{c}-0.0916^{* * *} \\
(0.0236)\end{array}$ & $\begin{array}{l}-0.0557 \\
(0.0515)\end{array}$ & 894 \\
\hline Other & $\begin{array}{c}-0.0167 \\
(0.0150)\end{array}$ & $\begin{array}{l}-0.0174 \\
(0.0155)\end{array}$ & $\begin{array}{c}-0.0390^{* * *} \\
(0.0142)\end{array}$ & $\begin{array}{l}-0.0369 \\
(0.0317) \\
\end{array}$ & 71 \\
\hline \multicolumn{6}{|l|}{ Panel C. Females } \\
\hline Humanities & $\begin{array}{c}0.0228 \\
(0.0158)\end{array}$ & $\begin{array}{l}-0.0112 \\
(0.0081)\end{array}$ & $\begin{array}{c}0.0539^{* *} \\
(0.0216)\end{array}$ & $\begin{array}{c}0.0211 \\
(0.0361)\end{array}$ & 160 \\
\hline Health/social/educ. & $\begin{array}{c}0.0035 \\
(0.0223)\end{array}$ & $\begin{array}{c}-0.0229^{* *} \\
(0.0101)\end{array}$ & $\begin{array}{c}0.0397 \\
(0.0274)\end{array}$ & $\begin{array}{l}-0.0092 \\
(0.0536)\end{array}$ & 189 \\
\hline Economics & $\begin{array}{c}0.0127 \\
(0.0271)\end{array}$ & $\begin{array}{c}-0.0188^{* *} \\
(0.0092)\end{array}$ & $\begin{array}{c}0.0369 \\
(0.0245)\end{array}$ & $\begin{array}{c}0.0199 \\
(0.0425)\end{array}$ & 280 \\
\hline STEM & $\begin{array}{c}0.0085 \\
(0.0266)\end{array}$ & $\begin{array}{l}-0.0142 \\
(0.0106)\end{array}$ & $\begin{array}{c}0.0273 \\
(0.0245)\end{array}$ & $\begin{array}{c}0.0099 \\
(0.0447)\end{array}$ & 289 \\
\hline Other & $\begin{array}{l}-0.0160 \\
(0.0272)\end{array}$ & $\begin{array}{c}-0.0126^{*} \\
(0.0075)\end{array}$ & $\begin{array}{c}0.0435^{* *} \\
(0.0200)\end{array}$ & $\begin{array}{c}0.0358 \\
(0.0283)\end{array}$ & 89 \\
\hline
\end{tabular}

Notes: The table shows effects of estimating equation (2) separately for all $4 \times 5$ combinations of occupational areas and major areas without regional controls and region-specific linear time trends. HSE = "health, social work, education". The dependent variables are new highly educated apprentices in the respective occupational area (columns), the treatment variable first-year BA students in the respective area of study (rows). Panel A refers to the total number of new highly educated apprentices, Panel $\mathrm{B}$ and $\mathrm{C}$ derive from separate regressions for males and females. Coefficients can be interpreted as semi-elasticities and represent the $\theta \times 100 \%$ change in new highly educated apprentices due to the average regional increase in first-year BA students in the respective area of study across the observation period from 1999-2011, which represents the mean in 2011 and is shown in the last column. All models include region and year fixed effects. Robust standard errors are clustered at the level of labor market regions and shown in parentheses. Significance level: ${ }^{* * *} \mathrm{p}<0.01,{ }^{* *} \mathrm{p}<0.05,{ }^{*} \mathrm{p}<0.1$. 
Table A-8: Detailed results for occupation-specific effects with controls

\begin{tabular}{|c|c|c|c|c|c|}
\hline \multirow{2}{*}{$\begin{array}{l}\text { First-year BA } \\
\text { students in... }\end{array}$} & HSE & Business & STEM & Other & \multirow{2}{*}{$\begin{array}{l}\text { Mean } \\
2011\end{array}$} \\
\hline & (1) & $(2)$ & $(3)$ & (4) & \\
\hline \multicolumn{6}{|l|}{ Panel A. Total } \\
\hline Humanities & $\begin{array}{c}0.0080 \\
(0.0145)\end{array}$ & $\begin{array}{l}-0.0033 \\
(0.0088)\end{array}$ & $\begin{array}{l}-0.0075 \\
(0.0137)\end{array}$ & $\begin{array}{l}-0.0254 \\
(0.0266)\end{array}$ & 230 \\
\hline Health/social/educ. & $\begin{array}{c}0.0089 \\
(0.0140)\end{array}$ & $\begin{array}{c}-0.0296^{* *} \\
(0.0136)\end{array}$ & $\begin{array}{l}-0.0238 \\
(0.0198)\end{array}$ & $\begin{array}{l}-0.0642 \\
(0.0390)\end{array}$ & 240 \\
\hline Economics & $\begin{array}{c}0.0149 \\
(0.0131)\end{array}$ & $\begin{array}{l}-0.0141 \\
(0.0116)\end{array}$ & $\begin{array}{c}-0.0439 * * * \\
(0.0157)\end{array}$ & $\begin{array}{l}-0.0411 \\
(0.0364)\end{array}$ & 593 \\
\hline STEM & $\begin{array}{c}0.0099 \\
(0.0184)\end{array}$ & $\begin{array}{l}-0.0204 \\
(0.0173)\end{array}$ & $\begin{array}{c}-0.0563^{* * *} \\
(0.0187)\end{array}$ & $\begin{array}{c}-0.0499 \\
(0.0431)\end{array}$ & 1184 \\
\hline Other & $\begin{array}{l}-0.0188 \\
(0.0178)\end{array}$ & $\begin{array}{c}-0.0193^{*} \\
(0.0110)\end{array}$ & $\begin{array}{l}-0.0214 \\
(0.0137)\end{array}$ & $\begin{array}{l}-0.0245 \\
(0.0245)\end{array}$ & 160 \\
\hline \multicolumn{6}{|l|}{ Panel B. Males } \\
\hline Humanities & $\begin{array}{l}-0.0275 \\
(0.0230)\end{array}$ & $\begin{array}{c}0.0104 \\
(0.0139)\end{array}$ & $\begin{array}{l}-0.0257 \\
(0.0172)\end{array}$ & $\begin{array}{c}-0.0579^{*} \\
(0.0325)\end{array}$ & 70 \\
\hline Health/social/educ. & $\begin{array}{c}0.0055 \\
(0.0243)\end{array}$ & $\begin{array}{l}-0.0250 \\
(0.0168)\end{array}$ & $\begin{array}{c}-0.0365^{*} \\
(0.0208)\end{array}$ & $\begin{array}{c}-0.1040^{* *} \\
(0.0454)\end{array}$ & 49 \\
\hline Economics & $\begin{array}{c}0.0036 \\
(0.0249)\end{array}$ & $\begin{array}{c}0.0013 \\
(0.0186)\end{array}$ & $\begin{array}{c}-0.0676^{* * *} \\
(0.0210)\end{array}$ & $\begin{array}{c}-0.0716^{*} \\
(0.0421)\end{array}$ & 313 \\
\hline STEM & $\begin{array}{c}0.0358 \\
(0.0320)\end{array}$ & $\begin{array}{l}-0.0117 \\
(0.0271)\end{array}$ & $\begin{array}{c}-0.0798^{* * *} \\
(0.0246)\end{array}$ & $\begin{array}{l}-0.0799 \\
(0.0494)\end{array}$ & 894 \\
\hline Other & $\begin{array}{c}-0.0241 \\
(0.0165)\end{array}$ & $\begin{array}{l}-0.0194 \\
(0.0171)\end{array}$ & $\begin{array}{c}-0.0386^{* *} \\
(0.0150)\end{array}$ & $\begin{array}{c}-0.0548^{*} \\
(0.0287)\end{array}$ & 71 \\
\hline \multicolumn{6}{|l|}{ Panel C. Females } \\
\hline Humanities & $\begin{array}{c}0.0186 \\
(0.0162)\end{array}$ & $\begin{array}{l}-0.0118 \\
(0.0087)\end{array}$ & $\begin{array}{c}0.0566^{* *} \\
(0.0225)\end{array}$ & $\begin{array}{c}0.0079 \\
(0.0377)\end{array}$ & 160 \\
\hline Health/social/educ. & $\begin{array}{c}0.0068 \\
(0.0180)\end{array}$ & $\begin{array}{c}-0.0285^{* *} \\
(0.0116)\end{array}$ & $\begin{array}{l}0.0516^{*} \\
(0.0272)\end{array}$ & $\begin{array}{l}-0.0128 \\
(0.0552)\end{array}$ & 189 \\
\hline Economics & $\begin{array}{c}0.0098 \\
(0.0203)\end{array}$ & $\begin{array}{c}-0.0225^{* *} \\
(0.0106)\end{array}$ & $\begin{array}{c}0.0384 \\
(0.0261)\end{array}$ & $\begin{array}{c}0.0088 \\
(0.0441)\end{array}$ & 280 \\
\hline STEM & $\begin{array}{c}0.0058 \\
(0.0208)\end{array}$ & $\begin{array}{l}-0.0195 \\
(0.0121)\end{array}$ & $\begin{array}{c}0.0329 \\
(0.0245)\end{array}$ & $\begin{array}{l}-0.0040 \\
(0.0508)\end{array}$ & 289 \\
\hline Other & $\begin{array}{l}-0.0208 \\
(0.0230)\end{array}$ & $\begin{array}{c}-0.0152^{*} \\
(0.0085)\end{array}$ & $\begin{array}{c}0.0417^{* *} \\
(0.0205)\end{array}$ & $\begin{array}{c}0.0222 \\
(0.0302)\end{array}$ & 89 \\
\hline \multicolumn{6}{|c|}{$\begin{array}{l}\text { Notes: The table shows effects of estimating equation (2) separately for all } 4 \times 5 \text { combinations of } \\
\text { occupational areas and major areas without region-specific linear time trends. HSE = "health, } \\
\text { social work, education". The dependent variables are new highly educated apprentices in the } \\
\text { respective occupational area (columns), the treatment variable first-year BA students in the } \\
\text { respective area of study (rows). Panel A refers to the total number of new highly educated } \\
\text { apprentices, Panel B and C derive from separate regressions for males and females. Coefficients } \\
\text { can be interpreted as semi-elasticities and represent the } \theta \times 100 \% \text { change in new highly educated } \\
\text { apprentices due to the average regional increase in first-year BA students in the respective area } \\
\text { of study across the observation period from } 1999-2011 \text {, which represents the mean in } 2011 \text { and } \\
\text { is shown in the last column. All models include region and year fixed effects as well as the } \\
\text { regional controls explained in Section } 4.2 \text {. Robust standard errors are clustered at the level } \\
\text { of labor market regions and shown in parentheses. Significance level: *** p<0.01, ** p<0.05, } \\
* \text { p }<0.1 \text {. }\end{array}$} \\
\hline
\end{tabular}


Table A-9: Detailed results for occupation-specific effects with controls and region-specific linear time trends

\begin{tabular}{|c|c|c|c|c|c|}
\hline \multirow{2}{*}{$\begin{array}{l}\text { First-year BA } \\
\text { students in... }\end{array}$} & HSE & Business & STEM & Other & \multirow{2}{*}{$\begin{array}{l}\text { Mean } \\
2011\end{array}$} \\
\hline & (1) & (2) & $(3)$ & $(4)$ & \\
\hline \multicolumn{6}{|l|}{ Panel A. Total } \\
\hline Humanities & $\begin{array}{c}0.0093 \\
(0.0222)\end{array}$ & $\begin{array}{l}-0.0114 \\
(0.0110)\end{array}$ & $\begin{array}{l}-0.0211 \\
(0.0296)\end{array}$ & $\begin{array}{c}0.0129 \\
(0.0313)\end{array}$ & 230 \\
\hline Health/social/educ. & $\begin{array}{c}0.0116 \\
(0.0314)\end{array}$ & $\begin{array}{c}-0.0310^{*} \\
(0.0161)\end{array}$ & $\begin{array}{c}-0.0570^{*} \\
(0.0310)\end{array}$ & $\begin{array}{c}0.0847 \\
(0.0595)\end{array}$ & 240 \\
\hline Economics & $\begin{array}{c}0.0594^{*} \\
(0.0307)\end{array}$ & $\begin{array}{l}-0.0116 \\
(0.0188)\end{array}$ & $\begin{array}{c}-0.0641^{* *} \\
(0.0315)\end{array}$ & $\begin{array}{c}-0.0145 \\
(0.0441)\end{array}$ & 593 \\
\hline STEM & $\begin{array}{c}0.0319 \\
(0.0527)\end{array}$ & $\begin{array}{l}-0.0355 \\
(0.0284)\end{array}$ & $\begin{array}{c}-0.0915^{* *} \\
(0.0366)\end{array}$ & $\begin{array}{c}0.1150 \\
(0.0879)\end{array}$ & 1184 \\
\hline Other & $\begin{array}{c}-0.0092 \\
(0.0244) \\
\end{array}$ & $\begin{array}{c}-0.0274^{* *} \\
(0.0129) \\
\end{array}$ & $\begin{array}{c}-0.0188 \\
(0.0295) \\
\end{array}$ & $\begin{array}{c}0.0317 \\
(0.0417) \\
\end{array}$ & 160 \\
\hline \multicolumn{6}{|l|}{ Panel B. Males } \\
\hline Humanities & $\begin{array}{l}-0.0046 \\
(0.0500)\end{array}$ & $\begin{array}{c}0.0153 \\
(0.0208)\end{array}$ & $\begin{array}{l}-0.0289 \\
(0.0329)\end{array}$ & $\begin{array}{c}0.0234 \\
(0.0487)\end{array}$ & 70 \\
\hline Health/social/educ. & $\begin{array}{c}0.0647 \\
(0.0397)\end{array}$ & $\begin{array}{c}0.0136 \\
(0.0158)\end{array}$ & $\begin{array}{c}-0.0674^{* * *} \\
(0.0222)\end{array}$ & $\begin{array}{l}-0.0069 \\
(0.0622)\end{array}$ & 49 \\
\hline Economics & $\begin{array}{c}0.0564 \\
(0.0740)\end{array}$ & $\begin{array}{l}0.0489^{*} \\
(0.0253)\end{array}$ & $\begin{array}{c}-0.1060^{* * *} \\
(0.0283)\end{array}$ & $\begin{array}{c}-0.0441 \\
(0.0560)\end{array}$ & 313 \\
\hline STEM & $\begin{array}{c}0.0640 \\
(0.1010)\end{array}$ & $\begin{array}{c}0.0260 \\
(0.0364)\end{array}$ & $\begin{array}{c}-0.1100^{* *} \\
(0.0457)\end{array}$ & $\begin{array}{c}0.1170 \\
(0.1300)\end{array}$ & 894 \\
\hline Other & $\begin{array}{l}-0.0349 \\
(0.0327)\end{array}$ & $\begin{array}{l}-0.0043 \\
(0.0140)\end{array}$ & $\begin{array}{c}-0.0458^{*} \\
(0.0243)\end{array}$ & $\begin{array}{c}0.0125 \\
(0.0371)\end{array}$ & 71 \\
\hline \multicolumn{6}{|l|}{ Panel C. Females } \\
\hline Humanities & $\begin{array}{c}0.0146 \\
(0.0209)\end{array}$ & $\begin{array}{c}-0.0259^{* *} \\
(0.0129)\end{array}$ & $\begin{array}{c}0.0403 \\
(0.0468)\end{array}$ & $\begin{array}{c}-0.0034 \\
(0.0572)\end{array}$ & 160 \\
\hline Health/social/educ. & $\begin{array}{c}0.0111 \\
(0.0402)\end{array}$ & $\begin{array}{c}-0.0443^{* *} \\
(0.0223)\end{array}$ & $\begin{array}{c}0.0532 \\
(0.0869)\end{array}$ & $\begin{array}{l}0.1990^{*} \\
(0.1080)\end{array}$ & 189 \\
\hline Economics & $\begin{array}{c}0.0565 \\
(0.0406)\end{array}$ & $\begin{array}{c}-0.0413^{*} \\
(0.0224)\end{array}$ & $\begin{array}{c}0.1380 \\
(0.0984)\end{array}$ & $\begin{array}{c}0.1210 \\
(0.0792)\end{array}$ & 280 \\
\hline STEM & $\begin{array}{c}0.0235 \\
(0.0443)\end{array}$ & $\begin{array}{l}-0.0497 \\
(0.0319)\end{array}$ & $\begin{array}{c}0.0106 \\
(0.0931)\end{array}$ & $\begin{array}{c}0.1380 \\
(0.1350)\end{array}$ & 289 \\
\hline Other & $\begin{array}{l}-0.0076 \\
(0.0261)\end{array}$ & $\begin{array}{l}-0.0240 \\
(0.0190)\end{array}$ & $\begin{array}{c}0.0947^{* *} \\
(0.0462)\end{array}$ & $\begin{array}{c}0.0664 \\
(0.0770)\end{array}$ & 89 \\
\hline \multicolumn{6}{|c|}{$\begin{array}{l}\text { Notes: The table shows effects of estimating equation (2) separately for all } 4 \times 5 \text { combinations } \\
\text { of occupational areas and major areas. HSE = "health, social work, education". The dependent } \\
\text { variables are new highly educated apprentices in the respective occupational area (columns), } \\
\text { the treatment variable first-year BA students in the respective area of study (rows). Panel } \\
\text { A refers to the total number of new highly educated apprentices, Panel B and C derive from } \\
\text { separate regressions for males and females. Coefficients can be interpreted as semi-elasticities } \\
\text { and represent the } \theta \times 100 \% \text { change in new highly educated apprentices due to the average } \\
\text { regional increase in first-year BA students in the respective area of study across the observation } \\
\text { period from } 1999-2011 \text {, which represents the mean in } 2011 \text { and is shown in the last column. All } \\
\text { models include region and year fixed effects as well as the regional controls explained in Section } \\
4.2 \text {. Robust standard errors are clustered at the level of labor market regions and shown in } \\
\text { parentheses. Significance level: } * * * \mathrm{p}<0.01, * * \mathrm{p}<0.05, * \mathrm{p}<0.1 \text {. }\end{array}$} \\
\hline
\end{tabular}


Table A-10: Robustness check for baseline effects: Excl. years 2000-2004

\begin{tabular}{|c|c|c|c|c|}
\hline & \multicolumn{3}{|c|}{ New highly educated apprentices } & \multirow{2}{*}{$\begin{array}{c}\text { Mean } \\
2011\end{array}$} \\
\hline & $(1)$ & $(2)$ & $(3)$ & \\
\hline \multicolumn{5}{|l|}{ Panel A. Total } \\
\hline First-year BA stud & $\begin{array}{c}-0.0275^{* *} \\
(0.0133)\end{array}$ & $\begin{array}{c}-0.0329^{* *} \\
(0.0157)\end{array}$ & $\begin{array}{c}-0.0544^{* *} \\
(0.0247)\end{array}$ & 2,628 \\
\hline \multicolumn{5}{|l|}{ Panel B. Males } \\
\hline Male first-year BA stud & $\begin{array}{c}-0.0534^{* * *} \\
(0.0168)\end{array}$ & $\begin{array}{c}-0.0571^{* * *} \\
(0.0170)\end{array}$ & $\begin{array}{l}-0.0483 \\
(0.0321)\end{array}$ & 1,488 \\
\hline \multicolumn{5}{|l|}{ Panel C. Females } \\
\hline Female first-year BA stud & $\begin{array}{l}-0.0063 \\
(0.0114)\end{array}$ & $\begin{array}{l}-0.0112 \\
(0.0150)\end{array}$ & $\begin{array}{l}-0.0489 \\
(0.0303)\end{array}$ & 1,139 \\
\hline Observations & 1,410 & 1,410 & 1,410 & \\
\hline Region FE & $\mathrm{x}$ & $\mathrm{x}$ & $\mathrm{x}$ & \\
\hline Year FE & $\mathrm{x}$ & $\mathrm{x}$ & $\mathrm{x}$ & \\
\hline Reg. controls & & $\mathrm{x}$ & $\mathrm{x}$ & \\
\hline Region $\times$ time trend & & & $\mathrm{x}$ & \\
\hline \multicolumn{5}{|c|}{$\begin{array}{l}\text { Notes: The table shows the average regional effect of first-year BA students on the number of } \\
\text { new highly educated apprentices excluding the years } 2000 \text { to } 2004 \text {. Panel A refers to the total } \\
\text { number of new highly educated apprentices, Panel B and C derive from separate regressions for } \\
\text { males and females. All models are estimated with a fixed effects Poisson estimator. Regional } \\
\text { controls consist of the variables explained in Section } 4.2 \text {. Coefficients can be interpreted as } \\
\text { semi-elasticities and represent the } \theta \times 100 \% \text { change in new highly educated apprentices due } \\
\text { to the average regional increase in first-year BA students across the observation period from } \\
\text { 1999-2011, which represents the mean in } 2011 \text { and is shown in the last column. Robust standard } \\
\text { errors are clustered at the level of labor market regions and shown in parentheses. Significance } \\
\text { level: } * * * p<0.01, * * \mathrm{p}<0.05, * \mathrm{p}<0.1 \text {. }\end{array}$} \\
\hline
\end{tabular}


Table A-11: Robustness check for baseline effects: Tuition fees

\begin{tabular}{|c|c|c|c|c|}
\hline & \multicolumn{3}{|c|}{ New highly educated apprentices } & \multirow{2}{*}{$\begin{array}{c}\text { Mean } \\
2011\end{array}$} \\
\hline & $(1)$ & $(2)$ & $(3)$ & \\
\hline \multicolumn{5}{|l|}{ Panel A. Total } \\
\hline First-year BA stud & $\begin{array}{c}-0.0100 \\
(0.0083)\end{array}$ & $\begin{array}{l}-0.0112 \\
(0.0077)\end{array}$ & $\begin{array}{c}-0.0553^{* * *} \\
(0.0179)\end{array}$ & 2,628 \\
\hline Tuition fees & $\begin{array}{l}0.0603^{*} \\
(0.0337)\end{array}$ & $\begin{array}{l}0.0555^{*} \\
(0.0327)\end{array}$ & $\begin{array}{c}-0.0217 \\
(0.0424)\end{array}$ & \\
\hline Fy BA stud $\times$ tuition fees & $\begin{array}{c}-0.0400^{* * *} \\
(0.0125)\end{array}$ & $\begin{array}{c}-0.0441^{* * *} \\
(0.0123)\end{array}$ & $\begin{array}{c}0.0028 \\
(0.0166)\end{array}$ & \\
\hline \multicolumn{5}{|l|}{ Panel B. Males } \\
\hline Male first-year BA stud & $\begin{array}{c}-0.0238^{* *} \\
(0.0120)\end{array}$ & $\begin{array}{c}-0.0218^{* *} \\
(0.0096)\end{array}$ & $\begin{array}{l}-0.0516^{*} \\
(0.0289)\end{array}$ & 1,488 \\
\hline Tuition fees & $\begin{array}{c}0.0916^{* *} \\
(0.0463)\end{array}$ & $\begin{array}{c}0.1070^{* *} \\
(0.0439)\end{array}$ & $\begin{array}{c}0.0251 \\
(0.0665)\end{array}$ & \\
\hline Male fy BA stud $\times$ tuition fees & $\begin{array}{c}-0.0554^{* * *} \\
(0.0153)\end{array}$ & $\begin{array}{c}-0.0550^{* * *} \\
(0.0151)\end{array}$ & $\begin{array}{l}-0.0037 \\
(0.0250)\end{array}$ & \\
\hline \multicolumn{5}{|l|}{ Panel C. Females } \\
\hline Female first-year BA stud & $\begin{array}{c}0.0012 \\
(0.0071)\end{array}$ & $\begin{array}{l}-0.0008 \\
(0.0075)\end{array}$ & $\begin{array}{c}-0.0393^{*} \\
(0.0228)\end{array}$ & 1,139 \\
\hline Tuition fees & $\begin{array}{c}0.0317 \\
(0.0423)\end{array}$ & $\begin{array}{c}0.0123 \\
(0.0422)\end{array}$ & $\begin{array}{l}-0.0516 \\
(0.0557)\end{array}$ & \\
\hline Female fy BA stud $\times$ tuition fees & $\begin{array}{l}-0.0249 \\
(0.0156) \\
\end{array}$ & $\begin{array}{c}-0.0330^{* *} \\
(0.0158) \\
\end{array}$ & $\begin{array}{c}0.0007 \\
(0.0229) \\
\end{array}$ & \\
\hline Observations & 2,115 & 2,115 & 2,115 & \\
\hline Region FE & $\mathrm{x}$ & $\mathrm{x}$ & $\mathrm{x}$ & \\
\hline Year FE & $\mathrm{x}$ & $\mathrm{x}$ & $\mathrm{x}$ & \\
\hline Reg. controls & & $\mathrm{x}$ & $\mathrm{x}$ & \\
\hline Region $\times$ time trend & & & $\mathrm{x}$ & \\
\hline
\end{tabular}

Notes: The table shows the average regional effect of first-year BA students on the number of new highly educated apprentices. Panel A refers to the total number of new highly educated apprentices, Panel B and C derive from separate regressions for males and females. Tuition fees is a dummy variable indicating whether tuition fees were in place in a certain region in a certain year. All models are estimated with a fixed effects Poisson estimator. Regional controls consist of the variables explained in Section 4.2. Coefficients can be interpreted as semi-elasticities and represent the $\theta \times 100 \%$ change in new highly educated apprentices due to the average regional increase in first-year BA students across the observation period from 1999-2011, which represents the mean in 2011 and is shown in the last column. Robust standard errors are clustered at the level of labor market regions and shown in parentheses. Significance level: *** $\mathrm{p}<0.01,{ }^{* *} \mathrm{p}<0.05,{ }^{*} \mathrm{p}<0.1$. 